GROUND-WATER AVAILABILITY FROM A DUNE-SAND AQUIFER NEAR COOS BAY AND NORTH BEND, OREGON

By M. A. Jones

U.S. GEOLOGICAL SURVEY

Open-File Report 90-563

Prepared in cooperation with the

COOS BAY-NORTH BEND WATER BOARD 


\section{U.S DEPARTMENT OF THE INTERIOR}

MANUEL LUJAN, JR., Secretary

U.S. GEOLOGICAL SURVEY

Dallas L. Peck, Director

For additional information write to:

District Chief

U.S. Geological Survey

10615 S.E. Cherry Blossom Drive

Portland, Oregon 97216
Copies of this report may be purchased from:

U.S. Geological Survey Books and Open-File Reports Section Federal Center, Box 25425

Denver, Colorado 80225 
Abstract-1.2.

Introduction-

Purpose and scope-1....... 3

We11-numbering system-1... 3

Acknowledgments

Hydrogeology - $\ldots \ldots$

Hydrogeologic framework-........... 5

Recharge and general hydrology-.... 7

Ground-water levels and movement-........ 9

Ground-water withdrawals-1...

Hydraulic properties of geologic units

Simulation of ground-water flow-_... 19

Mode1 construction-

Mode1 calibration-1...

Appraisal of seawater upconing

Critical pumpage-...

Fraction of seawater in pumped water.

Water availability-...

Maximizing ground-water pumpage-1... 43

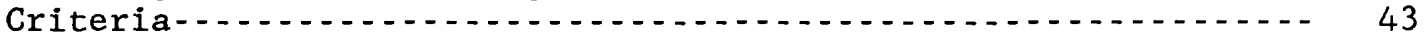

Results

Optimization of 1987 pumpage-1. 57

Possible improvements to the mode1

Summary and conclusions

References cited

Appendix A: Data input values for well pumpage, bottom altitudes of model layers, transmissivities, and leakage

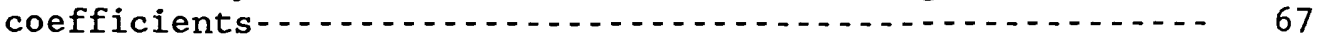




\section{ILLUSTRATIONS}

Page

Figure 1. Map showing location of the study area-_.............. 2

2. Diagram showing U.S. Geological Survey well-numbering

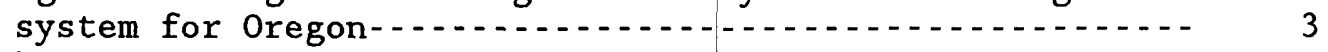

3. Schematic diagram showing dune-sand physiography-....... 4

4. Map showing surficial geology and altitude of the base of the Holocene-age sand deposit......... 6

5. Graphs showing water levels in Beale, Sandpoint, Spirit, Horsfall, and Bluebill Lakes for the 1984 water year-... 10

6. Graph showing monthly ground-water levels in two piezometers at the same location open to different depths in the dune aquifer, 1984 water year........

7. Graph showing relation of precipitation at the North Bend Federal Aviation Administration airport weather station to the water level in piezometer 24S/13W-33BAD01 for the 1984 water year.... 12

8. Map showing average water-table contours in the dune aquifer for the 1984 water year......... 13

9. Hydrogeologic section showing simulated movement of water

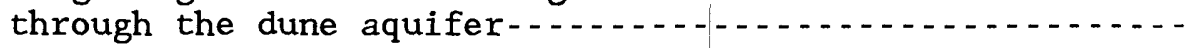

10-23. Maps showing:

10. Locations of existing and proposed production

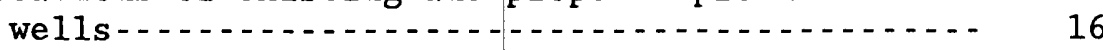

11. Transmissivity of the dune aquifer-........ 17

12. Model grid and location of pumped wells....... 20

13. Schematic geologic section through the northern part of model area showing the model layering-- 21

14. Location and type of discharge cells used

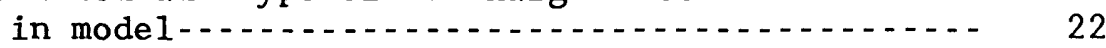

15. Rates of recharge used in model for the 1984

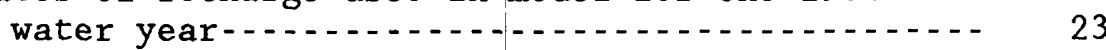

16. Model-input well pumpage for model layers ...... 26

17. Bottom altitudes of model layers........... 29

18. Simulated transmissivities for dune-sand

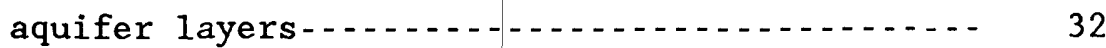

19. Simulated leakage coefficients between model layers 2 and 3 and layers 3 and $4 \ldots 33$

20. Simulated leakage coefficients for cells that discharge to the ocean-..... 34

21. Average observed water levels in wells and lakes, and contours of the simulated water levels in the upper layer of the model in the dune aquifer for the 1984 water year.......

22. Maximum landward extent of the simulated freshwater-seawater interface for the

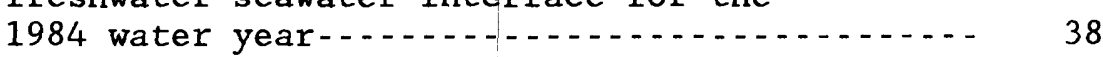

23. Location of generalized hydrogeologic sections-.- 39

24. Generalized hydrogeologic sections $B-B^{\prime}, C-C^{\prime}$, and $D-D^{\prime}$, showing the simulated position of the freshwater-

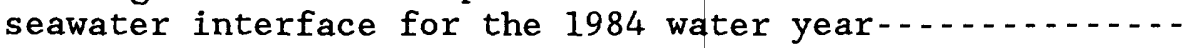


25-27. Maps showing the simulated water-level contours in the dune aquifer as a result of pumping:

25. 10 million gallons per day-.............. 45

26. 14 million gallons per day-............. 46

27. 17 million gallons per day-............... 47

28-30. Maps showing maximum landward extent of the simulated

freshwater-seawater interface as a result of pumping:

28. 10 million gallons per day................ 48

29. 14 million gallons per day -.............. 49

30. 17 million gallons per day ................. 50

31. Generalized hydrogeologic sections $B-B^{\prime}$ to $F-F^{\prime}$, showing

the simulated water levels and freshwater-seawater

interface positions as a result of pumping 10, 14,

and 17 million gallons per day-........... 52

32-33. Maps showing the maximum landward extent of the simulated freshwater-seawater interface for the:

32. Actual 1987 pumpage distribution-............ 58

33. Optimized 1987 pumpage distribution-.......... 59

34. Generalized hydrogeologic sections $B-B^{\prime}, C-C^{\prime}$, and $D-D^{\prime}$, showing the simulated freshwater-seawater interface positions for the actual 1987 pumpage and the

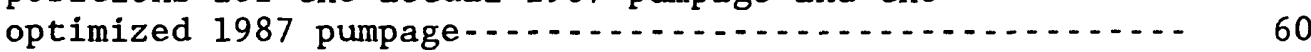

35. Map showing the actual and optimized distribution of

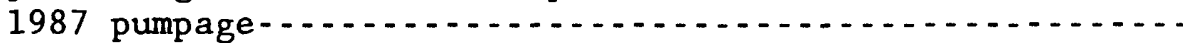

36. Map showing simulated water-level contours for the longterm average-annual recharge and actual 1987 pumpage-...-

\section{TABLES}

Table 1. Parameters used to determine the area-weighted average actual evapotranspiration for the study area...........

2. Annual-average pumping rates from 20 production wells in the dune aquifer for the 1984 water year........... 18

3. Partical-size analyses of fine-grained Tertiary deposits.... 19

4. Model-input surface-water heads for Tenmile Creek

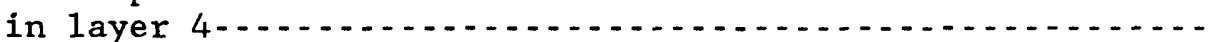

5. Ground-water pumping rates, calculated chloride concentrations, and simulated distance from bottom of the aquifer to the freshwater-seawater interface

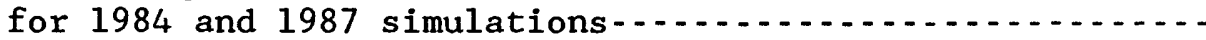

6. Ground-water pumping rates, calculated chloride concentrations, and simulated distance from bottom of the aquifer to the freshwater-seawater interface for three pumping simulations..................... 54

7. Lake-bottom altitudes and average simulated groundwater levels, in feet above sea level................. 


\section{CONVERSION FACTORS AND VERTICAL DATUM}

\begin{tabular}{|c|c|c|}
\hline Mu1tip1y & By & To obtain \\
\hline $\begin{array}{l}\text { inch (in.) } \\
\text { inch (in.) } \\
\text { foot (ft) } \\
\text { mile (mi) } \\
\text { acre } \\
\text { square mile }\left(\mathrm{mi}^{2}\right) \\
\text { gallon (gal) } \\
\text { cubic foot per second }\left(\mathrm{ft}^{3} / \mathrm{s}\right) \\
\text { million gallons per day (Mgal/d) } \\
\text { gallon per minute per foot } \\
\text { [ (gal/min)/ft] } \\
\text { foot per day (ft/d) } \\
\left.\text { foot squared per day ( } \mathrm{ft}^{2} / \mathrm{d}\right) \\
\text { parts per million (ppm) }\end{array}$ & $\begin{array}{l}2.54 \\
0.0254 \\
0.3048 \\
1.609 \\
4,047 \\
2.59 \\
3.785 \\
0.02832 \\
0.04381 \\
0.2070 \\
0.3048 \\
0.09290 \\
1,000\end{array}$ & $\begin{array}{l}\text { centimeter }(\mathrm{cm}) \\
\text { meter }(\mathrm{m}) \\
\text { meter }(\mathrm{m}) \\
\text { kilometer }(\mathrm{km}) \\
\text { square meter }\left(\mathrm{m}^{2}\right) \\
\text { square kilometer }\left(\mathrm{km}^{2}\right) \\
\text { liter }(\mathrm{L}) \\
\text { cubic meter per second }\left(\mathrm{m}^{3} / \mathrm{s}\right) \\
\text { cubic meter per second }\left(\mathrm{m}^{3} / \mathrm{s}\right) \\
\text { liter per second per meter } \\
\quad[(\mathrm{L} / \mathrm{s}) / \mathrm{m}] \\
\text { meter per day (m/d) } \\
\text { meter squared per day }\left(\mathrm{m}^{2} / \mathrm{d}\right) \\
\text { micrograms per } 1 \text { iter }(\mu \mathrm{g} / \mathrm{L})\end{array}$ \\
\hline
\end{tabular}

Sea leve1: In this report "sea level" refers to the National Geodetic Vertical Datum of 1929 (NGVD of 1929) - -a geodetic datum derived from a genera1 adjustment of the first-order level nets of both the United States and Canada, formerly called Sea Level Datum of 1929.

degree Fahrenheit $\left({ }^{\circ} \mathrm{F}\right)$ to degree Celsius $\left({ }^{\circ} \mathrm{C}\right):{ }^{{ }^{\circ}} \mathrm{C}=5 / 9\left({ }^{\circ} \mathrm{F}-32\right)$ 


\title{
GROUND-WATER AVAILABILITY FROM A DUNE-SAND AQUIFER NEAR COOS BAY AND NORTH BEND, OREGON
}

\author{
By M. A. Jones
}

\section{ABSTRACT}

A dune aquifer located on the Oregon coast near the communities of Coos Bay and North Bend is a 19.5-square-mile deposit of dune and marine sand of Holocene age. Presently (1987), about 5 million gallons per day is pumped from the aquifer for industrial and public supplies. The effects of increased ground-water pumpage from the aquifer to meet increasing demands for water are uncertain.

A multilayer numerical model was used to simulate ground-water flow in the dune aquifer and the position of the interface between the freshwater and underlying seawater. The model was calibrated using annual-averaged data, and used to simulate the long-term effects of different pumping alternatives on ground-water levels and interface positions. Model simulations indicate that 10 million gallons per day could be pumped with little risk of seawater intrusion into the dune aquifer. Although model simulations indicate that a maximum of 17 million gallons per day could be pumped without causing intrusion into the dune aquifer, the risk of intrusion associated with pumping this quantity over time is uncertain. Pumping 17 million gallons per day is equivalent to 45 percent of the average annual recharge of 38 inches per year.

Simulation indicates that the probability of present day (1987) pumpage causing seawater intrusion into the dune aquifer can be reduced by redistribution of withdrawals. Some pumpage from an existing north-south line of wells on the west side of the area would be transferred to an existing line of wells on the east side of the study area.

\section{INTRODUCTION}

The coastal communities of Coos Bay and North Bend are located along the southwestern coast of Oregon (fig. 1). Municipal and industrial water supplies for these two communities come from surface-water reservoirs and from ground-water wells located in the Oregon dunes adjacent to the two communities. About 5 million gallons per day was pumped from the aquifer for public and industrial supplies during 1987. Water use from the dune aquifer is 60 percent for industry and 40 percent for municipal and domestic use. This supplies all the water for industry located in the dune area, but only 40 percent of the municipal and domestic needs of the two communities. The other 60 percent of municipal and domestic need comes from surface-water reservoirs that are located to the southeast of the dune area.

Industrial and urban growth are increasing the demand for water in the area; however, the effects of increased ground-water development in the dune area are uncertain. The U.S. Geological Survey, in cooperation with the Coos Bay-North Bend Water Board (hereafter referred to as the Water Board), began a study to determine the quantity of ground water that could be developed in the area and to estimate the effects that increased ground-water withdrawals would have on ground-water levels and on seawater intrusion. This study was part of a broader study in conjunction with the Water Board that also included the investigation of geochemical processes and causes of large iron concentrations in the dune-sand aquifer. 


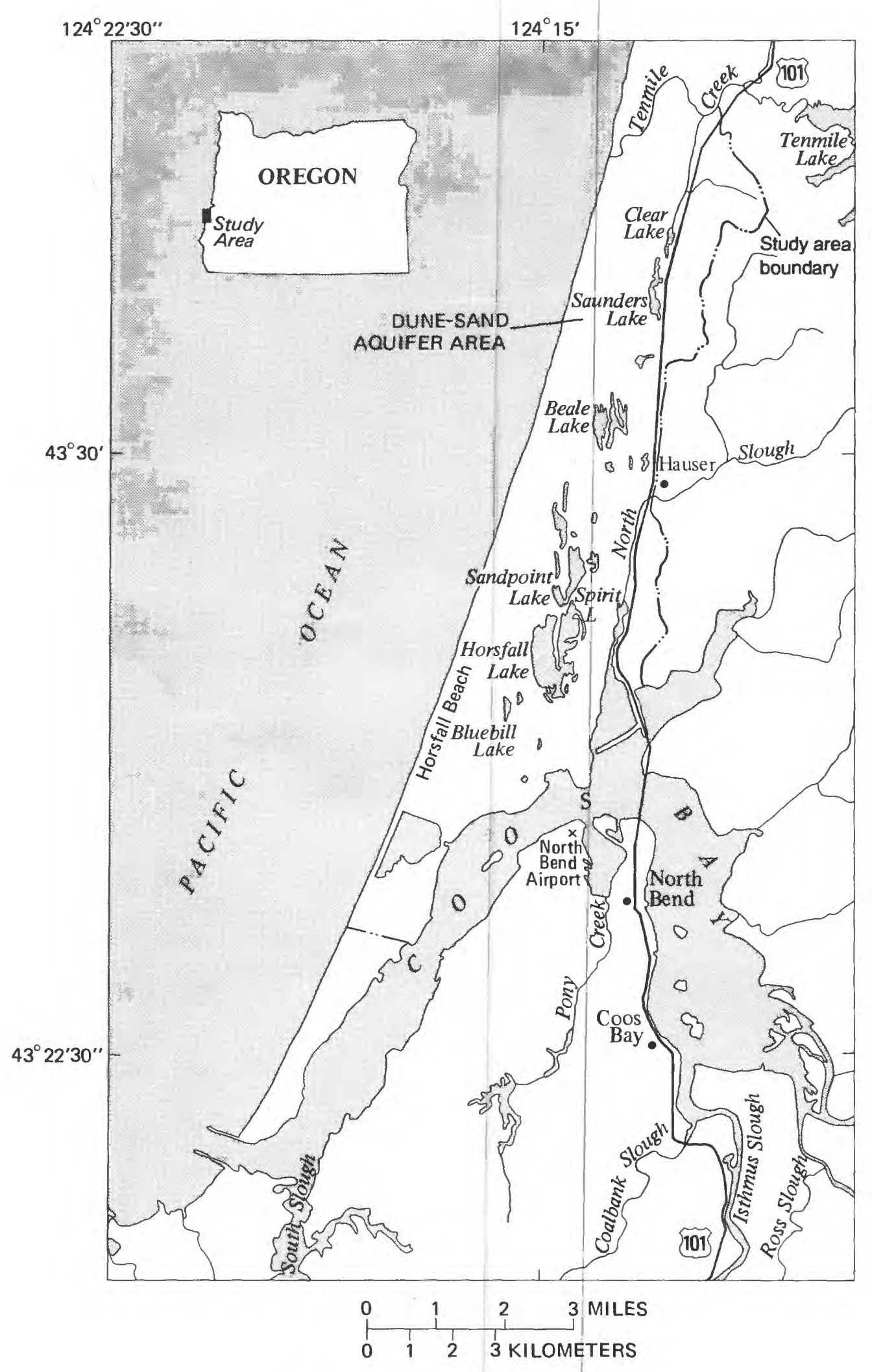

Figure 1.--Location of the study area. 


\section{Purpose and Scope}

The purpose of this investigation was to determine the quantity of ground water in the dune aquifer available for development. This report presents estimates of ground-water levels and locations of the freshwater-seawater interface that might occur as a result of increased ground-water development, and documents the procedures and data that were used for constructing and calibrating the numerical model used in this study.

A steady-state, four-1ayer numerical mode1 that simulates ground-water flow, ground-water levels, and the position of an interface between freshwater and seawater in the dune aquifer and underlying fine-grained sediments was constructed using a generalized model that was developed by Sapik (1988) . Geometry and initial estimates of the hydraulic properties of the geologic. units were obtained from drillers' logs, aquifer tests, water-level data from the Water Board, and data from a previous report by Robison (1973). The estimates of the hydraulic properties were changed systematically during the model-calibration procedure to determine which values of the properties gave the best agreement between model-simulated ground-water levels and the average observed ground-water level for the period October 1983 through September 1984.

The calibrated model was used to estimate average ground-water levels and positions of the freshwater-seawater interface for different ground-water pumping rates from the dune aquifer.

\section{We1l-Numbering System}

The well-location numbering system used in this report is shown in figure 2. Wells in Oregon are identified by township, range, section, and 10-acre subdivision within a section. We11 24S/13W-21CCD01 indicates successively, the township (24S), range (13W), and section (21). The first letter after the section number denotes the quarter section (160 acres); the second, the quarter-quarter section (40 acres); and the third, the quarter-quarter-quarter section (10 acres). Where two or more wells are in the same 10-acre subdivision, sequential numbers (01) are added after the third letter.

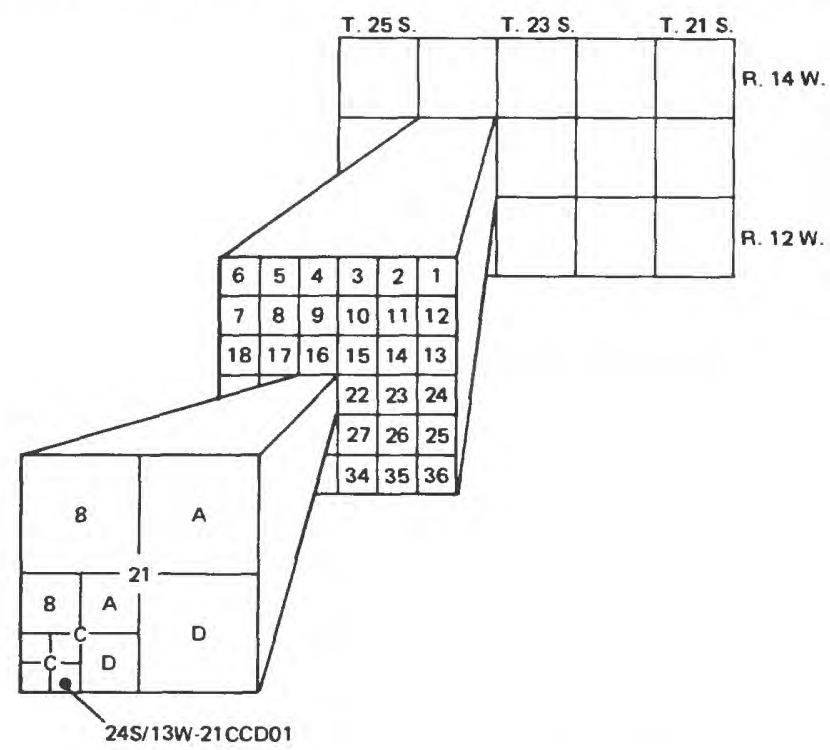

Figure 2.--Well-location numbering system. 


\section{Acknowledgments}

Special acknowledgment for assistance and information is given to King Phelps and Voneal Hayden of the Coos Bay-North Bend Water Board and to the U.S. Forest Service for permission to do field work within the Siuslaw National Forest.

\section{HYDROGEOLOGY}

The study area is about $24 \mathrm{mi}^{2}$ and is part of a discontinuous series of dunes extending the length of the Oregon coast. The area, located between Coos Bay and Tenmile Creek in Coos County (fig. 1), is about 13 miles long and 1.5 miles wide. About $19.5 \mathrm{mi}^{2}$ of this total area is covered with Holocene dune sand. The area also/contains Pleistocene and older fine-grained Tertiary marine deposits that rise steeply in the northeastern part of the area.

A diagram showing the physiography of the dune-sand area is shown in figure 3. Adjacent and parallel to the beach is a narrow 15- to 20foot-high ridge or foredune that was produced by offshore winds. It has been stabilized by beach grass at a height above the high-tide line and therefore is rarely breached by the ocean (Wiedemann, 1984). East of the foredune is a broad flat plain that lies 5 to 10 feet above sea level, formed by wind erosion and referred to here as the coastal deflation plain. It is one-quarter to one-half mile wide and continuous for the length of the project area. This flat plain commonly is saturated as a result of seasonal ground-water fluctuations and is predominately vegetated with lodgepole pine (Pinus contorta). Bare sand ridges, that in places reach altitudes greater than 100 feet above sea level, lie to the east of the coastal deflation plain. These ridges are composed of loose sand and are subject to shifting by winds. Eastward of the ridge is an older forested deflation plain. It lies 15 to 30 feet above sea level and contains a string of north-south-trending lakes. East of the older deflation plain is a second bare sand ridge that also reaches altitudes greater than 100 feet above sea level. To the southeast of this ridge lies North Slough, which drains into Coos Bay. To the north and east of North Slough lie forested hills of Pleistocene and older fine-grained deposits that range from 100 to 400 feet above sea level and rise steeply to the edge of the drainage area.

WEST

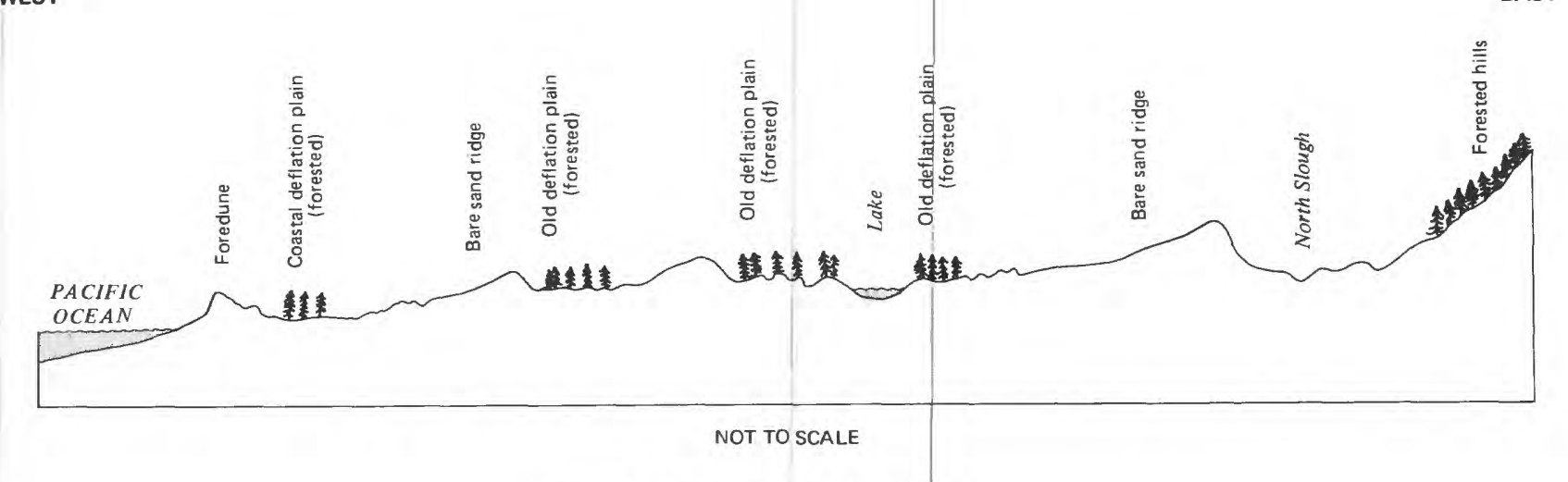

Figure 3.--Dune-sand physiography. 


\section{Hydrogeologic Framework}

The study area is predominantly covered by dune sand underlain by a marine sand, both of Holocene age. These deposits are underlain locally by Pleistocene-age marine deposits (Robison, 1973), but are most commonly underlain by older fine-grained Tertiary deposits. The fine-grained Tertiary deposits also underlie the Pleistocene deposits.

The older fine-grained Tertiary deposits consist of the Coaledo Formation and the Bastendorff Shale (Allen and Baldwin, 1944; and Baldwin, 1964). The Coaledo Formation is composed of siltstones, mudstones, and sandstones, and is exposed at land surface in the forested hills of the northeastern part of the study area (fig. 4). The Bastendorff Shale is not exposed at the surface within the study area, but it is thought to underlie the Pleistocene marine and Holocene dune- and marine-sand deposits (Robison, 1973). We11 logs of deeper wells in the dunes show clay or shale that is typical of the Bastendorff Shale near the bottom of the wells (Robison, 1973). A 2,300-foot section of the shale is exposed outside the study area about 1 mile south of the mouth of Coos Bay, where it conformably overlies the Coaledo Formation (A1len and Baldwin, 1944).

The Pleistocene marine deposits are exposed predominantly in the northeastern part of the study area. These deposits consist of slightly compacted and cemented sand and silt. They are littoral or strandline marine and terrace deposits that typically lie at altitudes of less than 120 feet, but to the north some exposures lie several hundred feet above sea level.

Permeabilities of the Pleistocene and fine-grained Tertiary deposits are relatively low. However, some wells completed in these deposits are an adequate source of freshwater for single-household domestic use (Robison, 1973).

The Holocene dune-sand deposit crops out to the west of the older Pleistocene marine deposits, consists of dune and marine sand, and herein is referred to as the dune-sand aquifer. The dune-sand aquifer is, with few exceptions, composed of loosely compacted and uncemented fine- to medium-grained sand. The exceptions are thin lenses of discontinuous silt and clay, which are present at the land surface and have been reported at depth by drillers.

The dune-sand aquifer is generally on the order of 100 feet thick. Maximum thickness is about 200 feet in the area near Horsfall and Spirit Lakes and thinnest in the northeastern part of the study area where it pinches out to zero. The thickness of the deposit varies because of differences in the surface topography and the altitude of the base of the deposit. The surface topography of this deposit ranges from 60 feet below sea level in the offshore region of the study area to over 100 feet above sea level in areas of the bare sand ridges. The altitude of the base of this deposit ranges from 180 feet below sea level in the area of Horsfall and Spirit Lakes to a few feet above sea level in the northeastern part of the study area (fig. 4). The dune-sand material was deposited by streams and rivers onto a broad, flat terrace that was cut into the Tertiary marine deposits during Pleistocene time. The sands at or near the land surface have since been reworked by the wind and ocean currents. The windblown sand is probably interbedded with sand that was deposited in the littoral zone when the sea was about 15 to 20 feet below the present sea level (Robison, 1973). Evidence of the littoral deposits is indicated by the presence of marine fossils reported by drillers. 


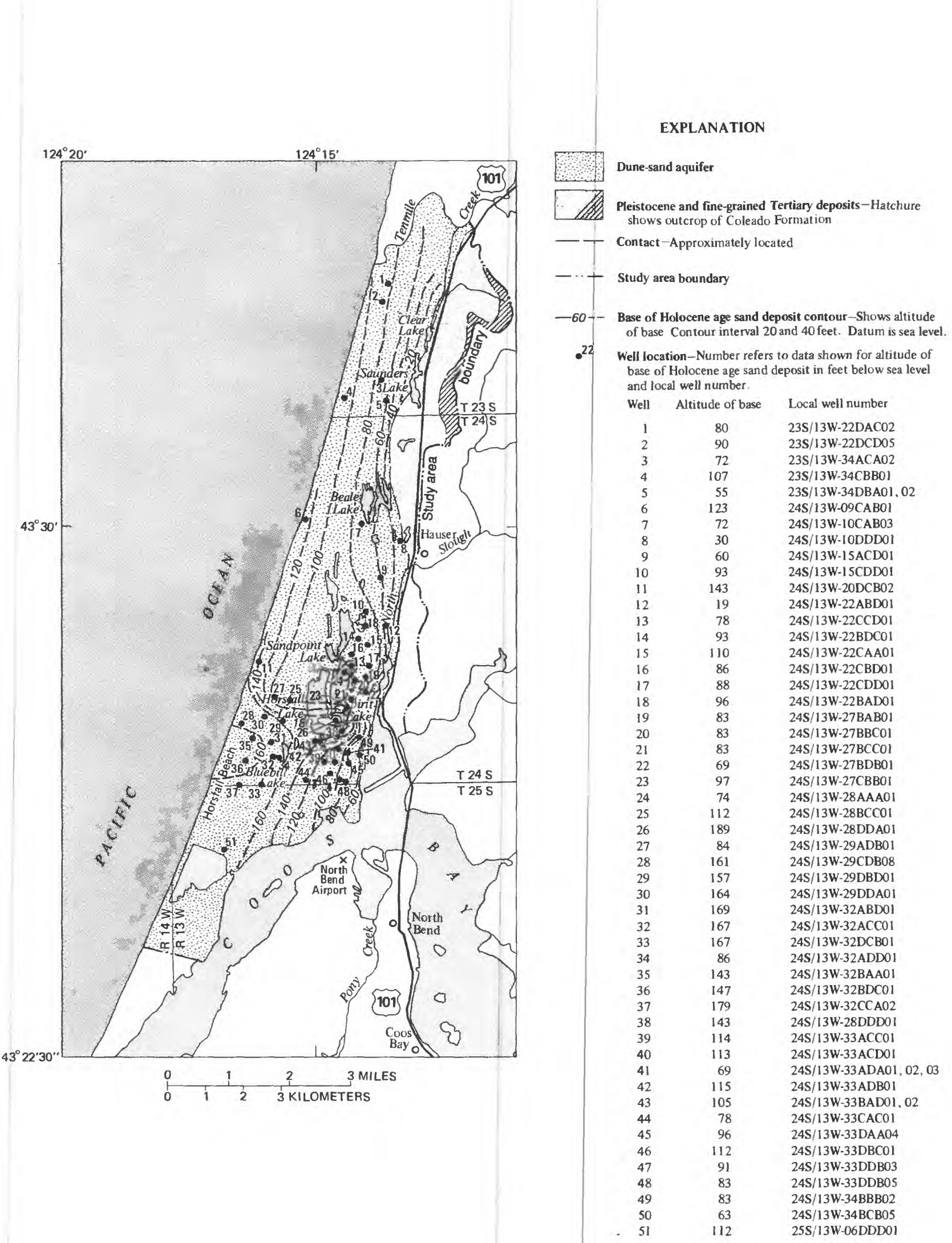

Figure 4.--Surficial geology and altitude of the base of the Holocene-age sand deposit (geology modified from Robison, 1973). 


\section{Recharge and General Hydrology}

The long-term average recharge to the dune aquifer was estimated using National Weather Service data on precipitation (P) and estimates of direct runoff (RO) and evapotranspiration (ET). The estimate of recharge (RE) was made by subtracting direct runoff and evapotranspiration from precipitation.

$$
\begin{gathered}
\mathrm{RE}=\mathrm{P}-\mathrm{RO}-\mathrm{ET} \\
\mathrm{RE}=63 \text { in. }-6 \text { in. }-19 \text { in. }=38 \text { in. }
\end{gathered}
$$

Mean annual precipitation used for this study was 63 inches, which is the average for the period 1903 through 1986 at North Bend FAA Airport (National Weather Service, written commun., 1987). The error for this figure is about 3 percent ( \pm 2 inches). About 80 percent of the precipitation occurs during the winter months October to March. Most of the precipitation falls as rain due to the temperate marine climate of the area. The mean annual temperature is $52{ }^{\circ} \mathrm{F}$. The coolest month of the year is January, with an average temperature of $45^{\circ} \mathrm{F}$, and the warmest is August, with an average temperature of $60^{\circ} \mathrm{F}$.

Direct runoff from the area is generally from Tenmile Creek and North Slough, but during winter, when lake and ground-water levels are highest, overland flow sometimes occurs in the broad undefined channels of the deflation plains. This overland flow is generally in a north-south direction with the water flowing into Coos Bay, Tenmile Creek, and North Slough. Direct runoff from the area was estimated to be 6 inches per year on the basis of an analysis of observed discharge hydrographs for Tenmile Creek. This runoff estimate is based on discharge for an area that is not representative of the entire study area, but only the northeastern (nondune) part. No discharge data are available for the dune area. Thus, the estimate for runoff in the dune area could be in error by as much as 100 percent ( \pm 6 inches). In order to refine the estimate of runoff, the discharge from the dune area would have to be monitored over one or more seasons during which runoff occurs.

The long-term actual evapotranspiration (AET) for the study area was estimated to be 19 inches per year. The potential evapotranspiration (PET), the quantity of evapotranspiration that would occur if water were nonlimiting, was calculated using the Blaney-Criddle method (U.S. Department of

Agriculture, 1970) and was used to limit or bound the AET number. The BlaneyCriddle method is empirical and uses latitude, monthly temperature, and experimental crop consumptive-use data. Under natural conditions, the AET is less than the PET because during some times of the year the amount of soil moisture available is insufficient to apply all the water required for potential evapotranspiration to occur. The soil-moisture calculations were based on long-term mean-monthly precipitation, available water capacities determined by the U.S. Department of Agriculture (1988, in press), and root depths estimated for the various vegetation types. The estimated 19 inches of AET is the area-weighted average for the different soil and vegetation types over the study area (table 1). As expected, this estimated AET is less than the evaporation pan data of 34 inches per year collected by Robison during the 1971 to 1973 water years (Robison, 1973). 
Because the PET estimates are based on calculations using equations developed for other climates and vegetation, and for soil types not verified for this location, the error in this estimate is probably about 25 percent $( \pm 5$ inches).

Table 1. - Parameters used to determine the area-weighted average actual evapotranspiration for the study area

[in./in., inches per inch; AET, actual evapotranspiration]

\begin{tabular}{|c|c|c|c|c|}
\hline Vegetation type & $\begin{array}{l}\text { Percentage } \\
\text { of total } \\
\text { area }\end{array}$ & $\begin{array}{l}\text { Root } \\
\text { depth } \\
\text { (feet) }\end{array}$ & $\begin{array}{l}\text { Available } \\
\text { water } \\
\text { capacities } \\
\text { (in./in.) }\end{array}$ & $\begin{array}{l}\text { Calculated } \\
\text { AET } \\
\text { (inches) }\end{array}$ \\
\hline Dune sand (no grass) & 22.5 & 1 & 0.05 & 16.87 \\
\hline Dune sand (grass) & 22.5 & 2 & .07 & 17.95 \\
\hline Marsh & 2.0 & - & - & $a_{18}$ \\
\hline Water bodies & 5.0 & -- & 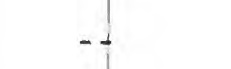 & $\mathrm{b}_{24}$ \\
\hline Shrubs & 12.0 & 3 & .07 & 18.36 \\
\hline Forest & 36.0 & $4-5$ & $.07-.25$ & $c_{20.66}$ \\
\hline Average & & & & $d_{19.3}$ \\
\hline $\begin{array}{l}\text { a Estimated value } \\
\text { b Value from Robison } \\
\text { c Areally weighted av } \\
d_{\text {Areally weighted av }}\end{array}$ & $\begin{array}{l}\text { 973) } \\
\text { age for al1 } \\
\text { age for all }\end{array}$ & $\begin{array}{l}\text { rest } \\
\text { ceas }\end{array}$ & is & \\
\hline
\end{tabular}

Similar computations done for the 1984 water year (October 1983 through September 1984), during which the precipitation (76 inches) was greater than the long-term average, yielded an evapotranspiration of 21 inches and an average recharge to the dune aquifer of 47 inches. The expected error in the estimated long-term average recharge to the dune aquifer ( $R E=38$ in.) is the square root of the sum of the squares of the errors in P, RO, and ET;

$$
\sqrt{(2)^{2}+(6)^{2}+(5)^{2}}= \pm 8 \text { inches }
$$

The long-term average recharge from precipitation to the dune aquifer was estimated by using a water budget as described in the preceding paragraphs. A water budget was not used to estimate recharge in the northeast part of the study area, where fine-grained deposits occur at land surface, because of insufficient data for this area and the likelihood that the fine-grained deposits would inhibit the infiltration of water. For this area, an arbitrarily small value of recharge equal to 10 percent of precipitation is assumed. The actual quantity of recharge in this part of the study area probably is larger than this assumed amount, but it is used in this study to obtain a conservative (low) estimate of water availability. 
The actual quantity of recharge to the fine-grained deposits in the northeast part of the study area could be as much as 38 inches, the average quantity for the dune aquifer, but probably is not less than the assumed 10 percent of precipitation ( 6.3 inches). Consequently, the error in the estimated recharge for this area is between -32 and 0 inches.

The error in the areal average recharge to the study area can be estimated by combining the error in recharge to the dune aquifer, which occupies about three-quarters of the land area, with the error in recharge to the northeastern area with fine-grained deposits, which occupies about one-quarter of the total land area. The areal average recharge is

$$
3 / 4 \text { (38 in.) }+1 / 4(6 \text { in. })=30 \text { in. }
$$

The estimated error in this figure is

$$
-\sqrt{[3 / 4(8)]^{2}+[1 / 4(32)]^{2}} \text { to }+\sqrt{[3 / 4(8)]^{2}+[1 / 4(0)]^{2}} \text { in. , }
$$

which is

10 to +6 in.

or

33 to 20 percent.

A negative error indicates that the estimated value of recharge is less than the actual value. Presumably, an estimate of water availability based on a low estimate of recharge also would be low. A positive error indicates the opposite.

\section{Ground-Water Levels and Movement}

Ground-water levels were measured monthly at most wells. In a few wells, measurements were made only in January, March, and June. Most water levels were measured relative to reference marks whose altitudes had been surveyed to an accuracy greater than 0.1 foot during the 1960's by the Water Board.

Water levels in the lakes are an expression of the water table and are continuous with the dune aquifer (Robison, 1973). Altitudes of the water levels for five of the nine large lakes are observed weekly by the Water Board from staff gages that have surveyed datums. During the dry summer months, water is pumped from wells to Horsfall, Spirit, and Sandpoint Lakes to artificially maintain the water levels for recreational purposes.

Seasonal variations of water levels in the lakes and the wells are similar. Seasonal variation in the five lakes that contain staff gages is shown in figure 5 and seasonal variation of monthly water levels in two piezometers near the southeastern end of Horsfall Lake is shown in figure 6. The piezometers are at the same location but are completed at different depths in the dune aquifer (see fig. 4).

Water-level variations in the five lakes ranged from 2.4 to 4 feet for this same period. Historically, the lakes have been observed to have varied 3 to 6 feet (Robison, 1973). Seasonal variations in measured ground-water levels during the 1984 water year ranged from 1.4 to 4.9 feet for wells in the study area. The monthly precipitation for the 1984 water year, together with the water levels in well 24S/13W-33BAD01, is shown 


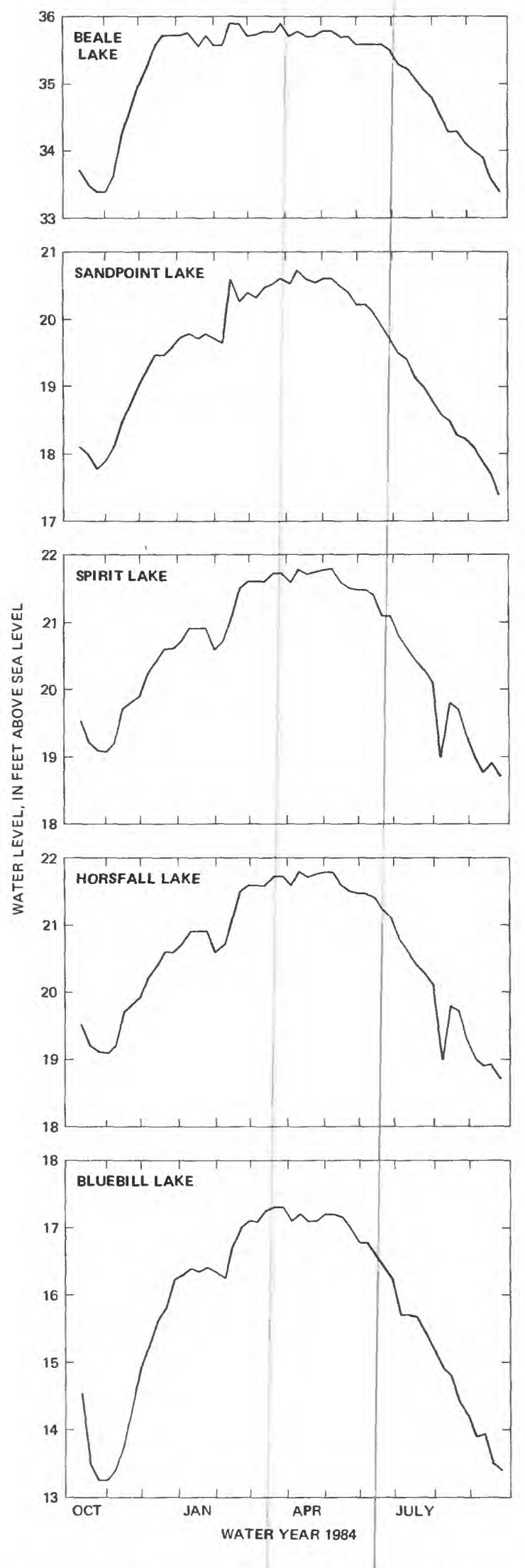

Figure 5.--Water levels in Beale, Sandpoint, Spirit, Horsfall, and Bluebill Lakes for the 1984 water year. 


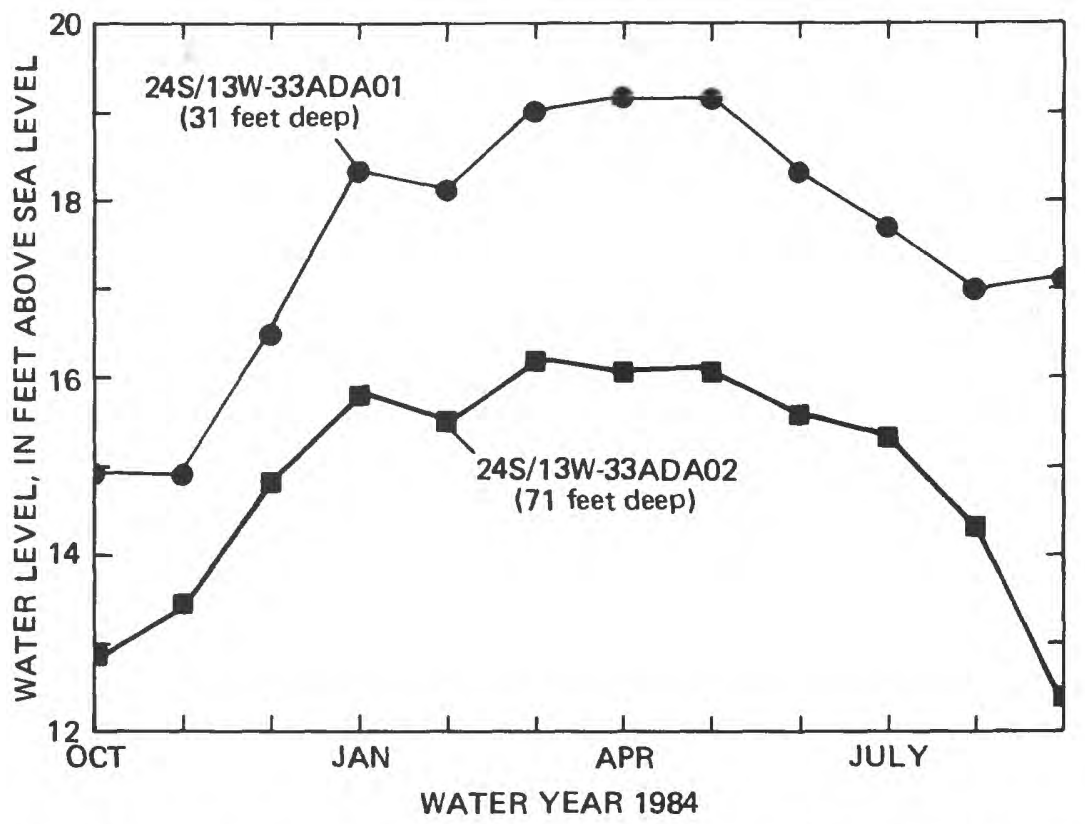

Figure 6.--Monthly ground-water levels in two piezometers at the same location open to different depths in the dune aquifer, 1984 water year.

in figure 7 (we11 location shown in figure 4). The seasonal water-level variations indicate that both the lakes and dune aquifer respond quickly to recharge from precipitation.

The average observed water levels in wells and lakes for the 1984 water year are shown in figure 8 . The contours in figure 8 are based on water levels in shallow wells (generally less than 50 feet deep) in the upper onethird of dune aquifer and lake stages in the area.

Water-table contours in figure 8 indicate that the general direction of ground-water flow in the dune aquifer is towards the Pacific Ocean, Coos Bay, North Slough, and Tenmile Creek. Horizontal ground-water gradients north of Beale Lake are as much as 50 feet per mile from east to west. South of Beale Lake, the ground water flows eastward toward North Slough, westward toward the Pacific Ocean, and southward through or beneath Horsfall and Spirit Lakes toward Coos Bay with gradients from 10 to 30 feet per mile.

Due in part to particle orientation and to the presence of thin, discontinuous layers of clay and silt, the vertical hydraulic conductivity of the dune aquifer is probably less than the horizontal conductivity. Waterlevel measurements in most areas where there are shallow and deep wells indicate that there is a downward component of the hydraulic gradient (fig. 6). In wells near the coast and North Slough, the gradient is probably upward with upward discharge to the ocean or bay. The maximum vertical difference observed in the average-annual water levels in pairs of closely spaced piezometers during the 1984 water year was 2.5 feet. This 2.5 -foot difference was observed in the piezometer pair 24S/13W-33ADA01 (31 feet deep) and 24S/13W-33ADA02 ( 71 feet deep). The difference indicates a vertical head gradient of $0.06 \mathrm{ft} / \mathrm{ft}$ in the dune aquifer. Vertical head differences in six closely spaced piezometer pairs in the dune aquifer ranged from 0.1 to 

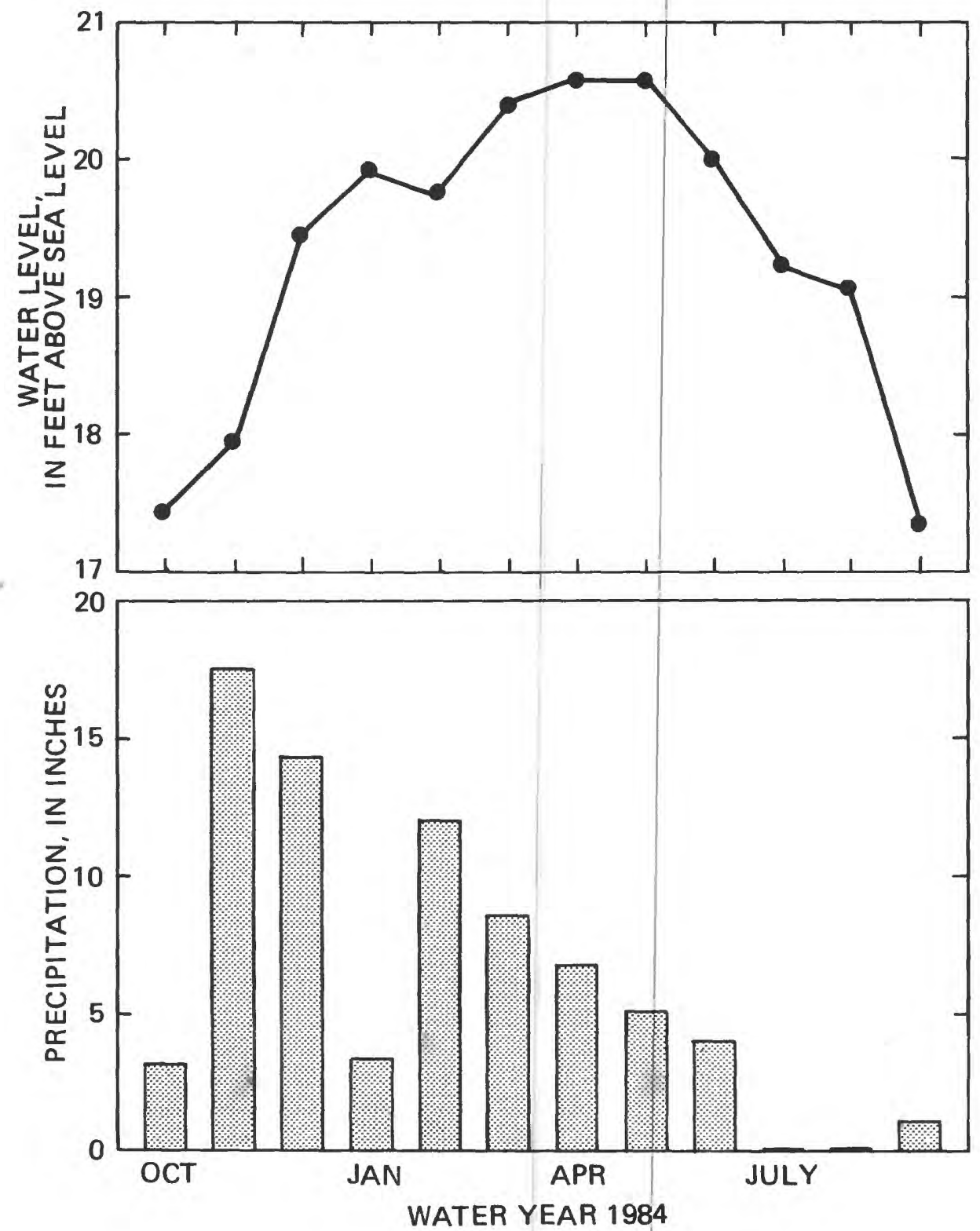

Figure 7.--Relation of precipitation at the North Bend Federal Aviation Administration airport weather station to the water level in piezometer 24S/13W-33BAD01 for the 1984 water year.

2.5 feet; vertical gradients ranged from 0.002 to $0.06 \mathrm{ft} / \mathrm{ft}$. Although there is a vertical component of flow, the predominant component of flow in the study area is horizontal, as shown in figure 9. This figure illustrates the direction of flow and the distribution of head indicated by the computer model of ground-water flow described in a later section. 


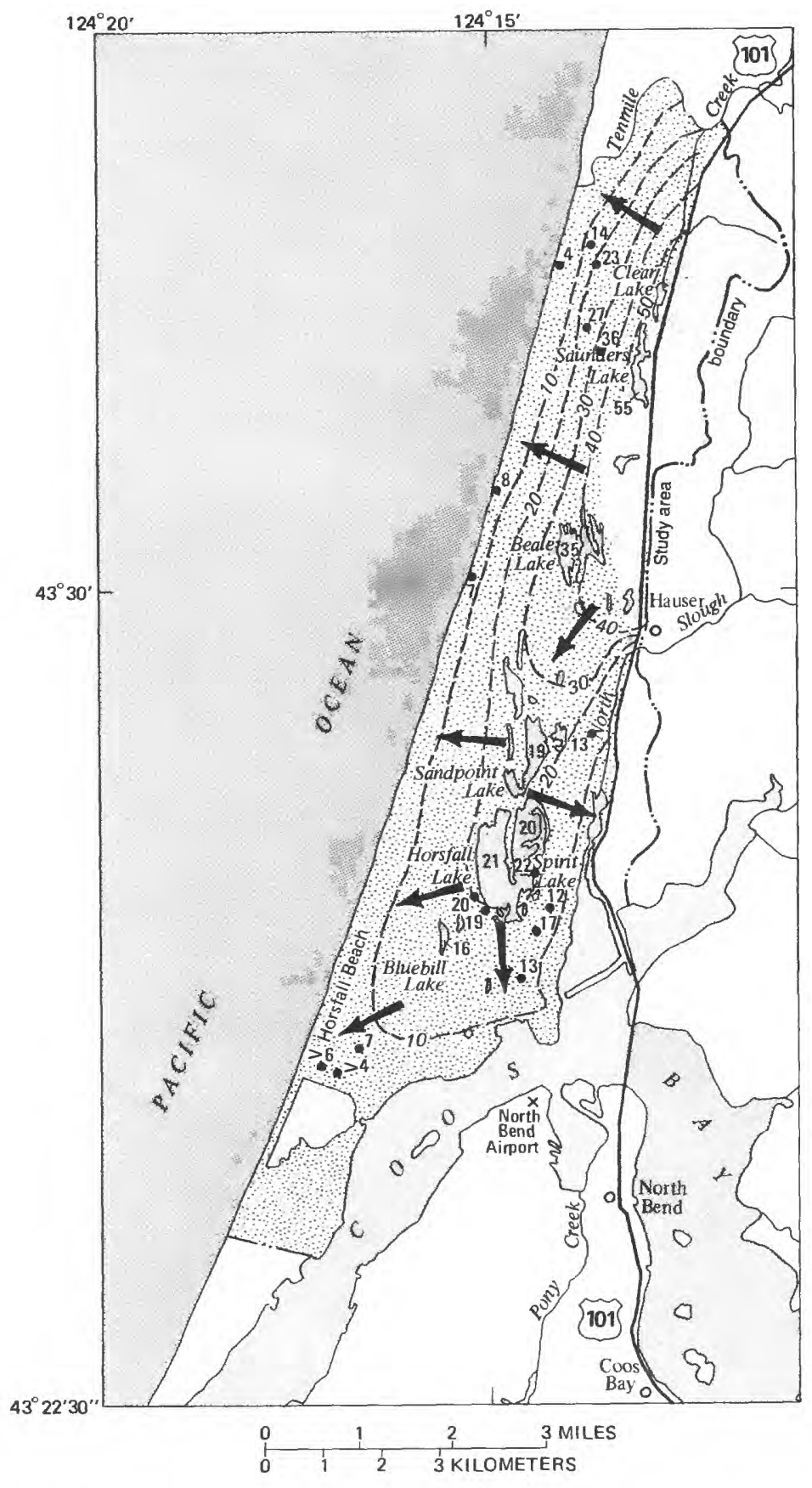

EXPLANATION

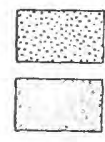

Dune-sand aquifer

Pteistocene and fine-grained Tertiary deposits

- - Study area boundary

- -10-- Water-table contour-Shows altitude of averageannual water level for water year 1984. Contour interval $10 \mathrm{feet}$. Datum is sea level.

Direction of ground-water flow

13 Well location-Number is average water level for water year 1984, in feet above sea level.

$>$ indicates greater than given value.

21

Lake level-Number shown is altitude of water level, in feet above sea level.

Figure 8.--Average water-table contours in the dune aquifer for the 1984 water year. 


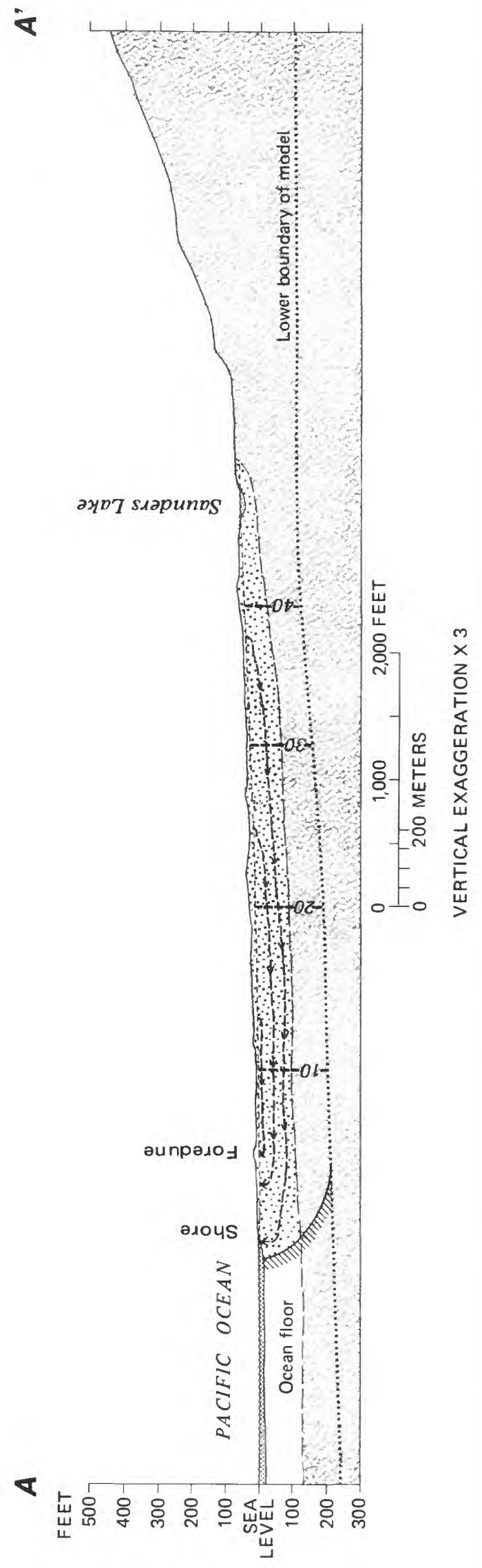

ปิ 


\section{Ground-Water Withdrawals}

Quantities of ground water pumped during the 1984 water year from 20 production wells located in the southern part of the dunes and operated by the Water Board are listed in table 2. At present (1987) these same 20 wells pump at rates of 3 to $7.5 \mathrm{Mgal} / \mathrm{d}$ (million gallons per day).

Original plans by the Water Board for full development of the dune aquifer called for construction of 64 wells capable of producing $30 \mathrm{Mgal} / \mathrm{d}$ in two north-south parallel lines of wells with Snag, Sandpoint, Horsfa1l, and Spirit Lakes between (fig. 10). The western line extends from near the south end of the project area north to Tenmile Creek and includes 40 ( 1 through .40) proposed production wells and 6 (41 through 46) existing production wells. The eastern line extends from the south end of the area north only to about the town of Hauser and includes 4 (61 through 64) proposed production wells and 14 ( 47 through 60 ) existing production wells. Full development of the aquifer will depend on the quantity and quality of water available.

Pumpage from shallow single-household domestic wells in the dune aquifer was estimated to be $250 \mathrm{gal} / \mathrm{d}$ per well (King Phelps, Coos Bay-North Bend Water Board, oral commun., 1987). Much of this water is returned to the groundwater system by septic systems and percolation of irrigation water; thus, consumptive use of water from the domestic wells was estimated to be one-third of that pumped, or about $83 \mathrm{gal} / \mathrm{d}$ per well.

\section{Hydraulic Properties of Geologic Units}

Robison (1973) computed transmissivities of the dune aquifer from aquifer pump tests and prepared a map of the transmissivities for the study area. Transmissivities ranged from $6,000 \mathrm{ft}^{2} / \mathrm{d}$ (feet squared per day) in the northern half of the study area to $16,000 \mathrm{ft}^{2} / \mathrm{d}$ in the southern half. Average values were about half these amounts (fig. 11). The horizontal hydraulic conductivity obtained by dividing transmissivity by thickness is in the order of $100 \mathrm{ft} / \mathrm{d}$ (about $10^{-3} \mathrm{ft} / \mathrm{s}$ ). During model calibration in the present study, Robison's transmissivities of the dune aquifer were adjusted upward by 28 percent (see section "Model Calibration").

Specific capacities from bailing tests on 16 wells were available for estimating the transmissivity of the Pleistocene marine deposits exposed at the surface in the northeastern corner of the study area. The specific capacity of a well is defined as the withdrawal rate divided by the drawdown in the well. An approximate estimate of the transmissivity of the screened interval of an aquifer was obtained using the simplified formula derived from Brown (1963):

Transmissivity in $\mathrm{ft}^{2} / \mathrm{s} .=0.003 \mathrm{x}$ specific capacity in $(\mathrm{gal} / \mathrm{min}) / \mathrm{ft}$

The transmissivity value for each well was divided by the length of the screened or perforated interval to obtain $k$ (horizontal hydraulic conductivity). Values of $k$ ranged from $0.05^{\mathrm{x}} \mathrm{ft} / \mathrm{d}\left(0.5 \times 10_{-6} \mathrm{ft} / \mathrm{s}\right)$ to $314 \mathrm{ft} / \mathrm{d}$ $\left(3.63 \times 10^{-3} \mathrm{ft} / \mathrm{s}\right)$. The median value $8.6 \mathrm{ft} / \mathrm{d}\left(0.1 \times 10^{-3} \mathrm{ft} / \mathrm{s}\right)$ was used in the numerical model. 


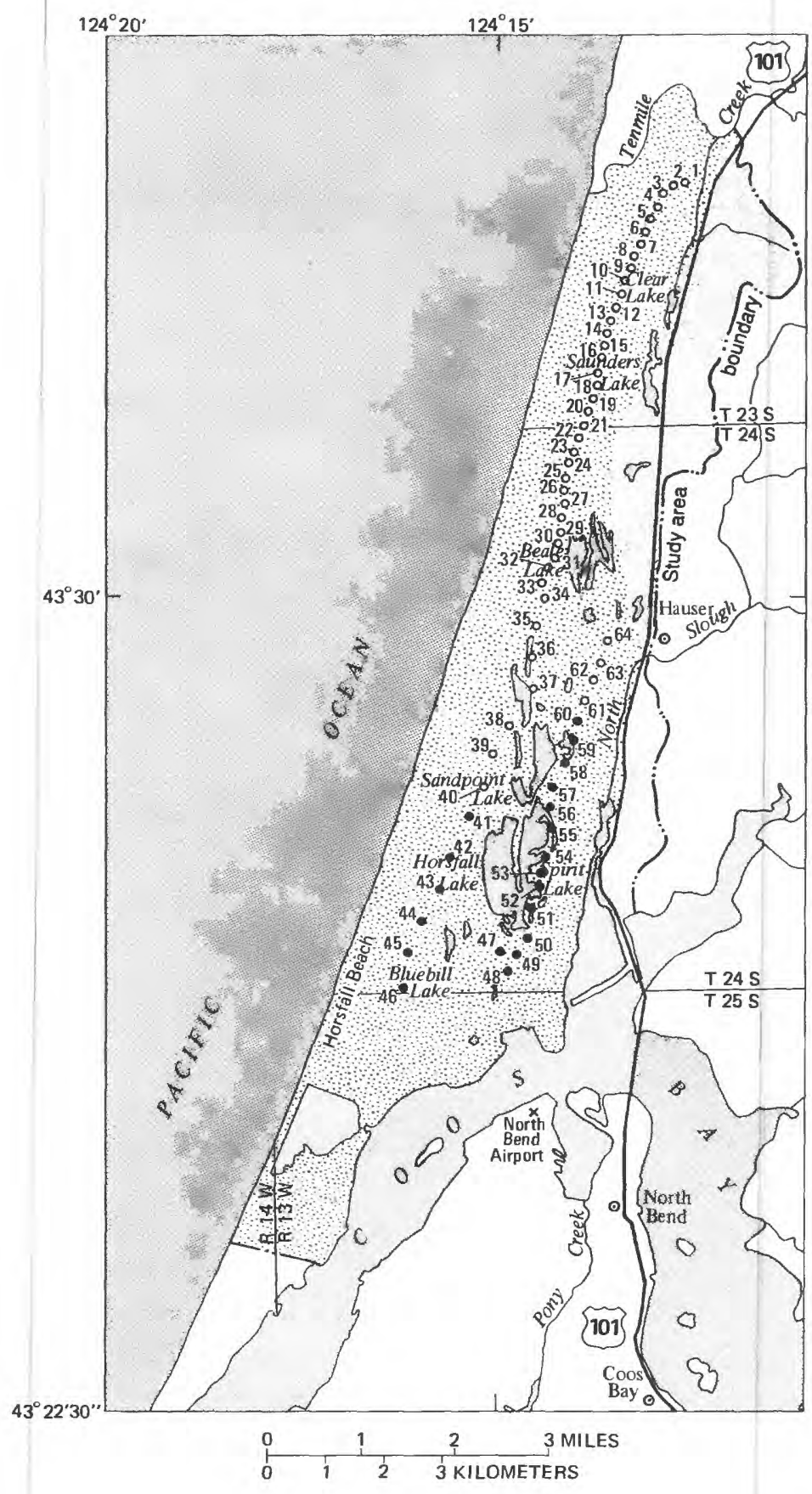

EXPLANATION

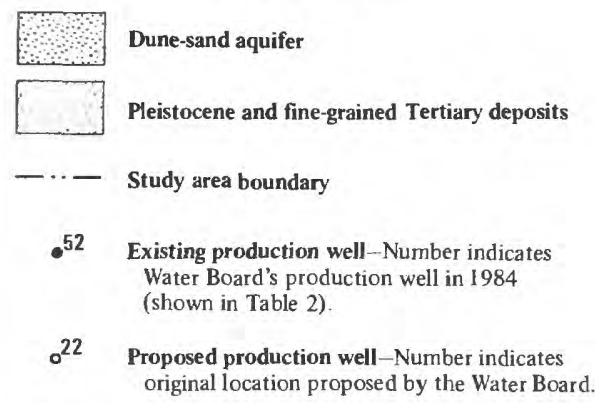

Figure 10.--Locations of existing and proposed production wells. 

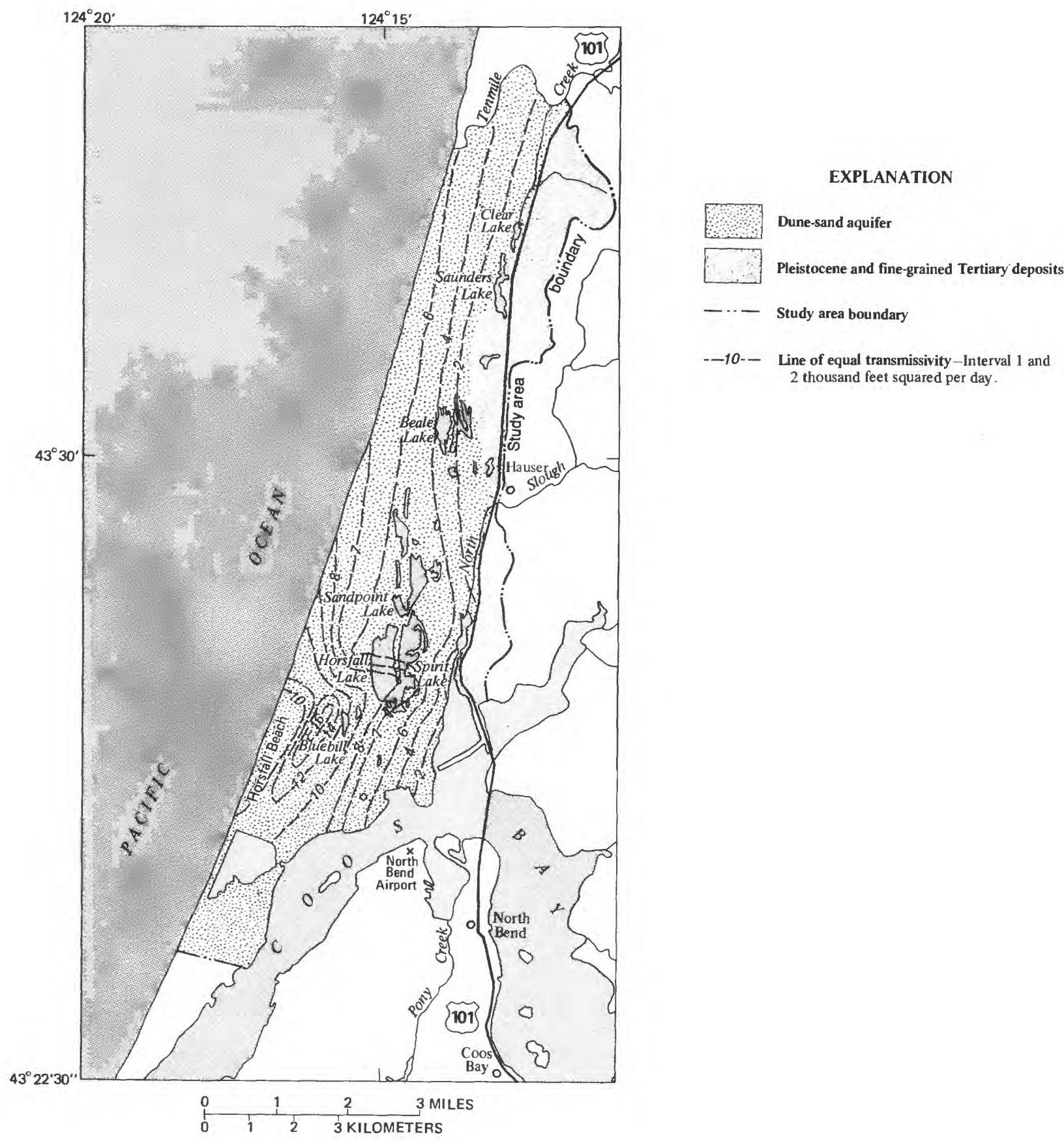

Figure 11.--Transmissivity of the dune aquifer (modified from Robison, 1973). 
Table 2.--Annual-average pumping rates from 20 production we11s in the dune aquifer for the 1984 water year

[Mgal/d, million gallons per day; $\mathrm{ft}^{3} / \mathrm{s}$, cubic feet per second]

We11 site

number

shown on

figure

10

(nod

\begin{tabular}{|c|c|c|c|c|c|}
\hline 41 & $24 \mathrm{~S} / 13 \mathrm{~W}-21 \mathrm{CDC} 01$ & 3,2 & 23,13 & 0.180 & 0.279 \\
\hline 42 & $-28 \mathrm{BCC} 01$ & $4,3,2$ & 24,12 & .103 & .159 \\
\hline 43 & $-29 D D A 01$ & 2 & 25,12 & .260 & .402 \\
\hline 44 & $-32 A B D 01$ & 2 & 26,12 & .375 & .580 \\
\hline 45 & $-32 A C C 01$ & $4,3,2$ & 27,11 & .334 & .517 \\
\hline 46 & $-32 \mathrm{ACC} 02$ & 3,2 & 28,12 & .396 & .613 \\
\hline 47 & $-33 A C C 01$ & $4,3,2$ & 27,16 & .002 & .003 \\
\hline 48 & $-33 D B C 01$ & 3,2 & 27,17 & .002 & .003 \\
\hline 49 & $-33 \mathrm{ACD} 01$ & 3,2 & 26,17 & .002 & .003 \\
\hline 50 & $-33 A D B 01$ & $4,3,2$ & 26,18 & .008 & .012 \\
\hline 51 & $-33 \mathrm{AAB} 01$ & 4,3 & 25,18 & .012 & .019 \\
\hline 52 & $-28 D D A 01$ & $4,3,2$ & 25,18 & .016 & .025 \\
\hline 53 & $-27 \mathrm{CBB} 01$ & $4,3,2$ & 24,18 & .213 & .330 \\
\hline 54 & $-27 \mathrm{BCC} 01$ & $4,3,2$ & 24,18 & .232 & .359 \\
\hline 55 & $-27 \mathrm{BBC} 01$ & $4,3,2$ & 23,18 & .240 & .371 \\
\hline 56 & $-22 \mathrm{BBC} 01$ & $4,3,2$ & 22,17 & .138 & .214 \\
\hline 57 & -22 CBDO1 & 3,2 & 22,17 & .305 & .472 \\
\hline 58 & $-22 \mathrm{BDC} 01$ & 3,2 & 21,17 & .205 & .317 \\
\hline 59 & $-22 \mathrm{BAD} 01$ & 3,2 & 21,18 & .335 & .518 \\
\hline 60 & $-15 \mathrm{CCD} 01$ & 2 & 20,18 & .350 & .542 \\
\hline
\end{tabular}

There are no data for making an accurate determination of the hydraulic conductivity of the fine-grained Tertiary deposits. However, sieve analyses of samples of these deposits from four different locations (table 3 ) indicates that the material is predominantly finer than 0.063 millimeter (silts and clays). Horizontal hydraulic conductivities of material of this type are typically less than $3 \mathrm{ft} / \mathrm{d}$ (Freeze and Cherry, 1979, p. 29). The value used in the numerical model was $0.17 \mathrm{ft} / \mathrm{d}\left(2 \times 10^{-6} \mathrm{ft} / \mathrm{s}\right)$, which is about one fivehundredth of the conductivity of dune sand. 
Table 3.--Partical-size analyses of fine-grained Tertiary deposits

\begin{tabular}{rccc}
\hline $\begin{array}{l}\text { Well sample } \\
\text { location } \\
\text { (shown in } \\
\text { figure 3) }\end{array}$ & $\begin{array}{l}\text { Depth below } \\
\text { land surface, } \\
\text { in feet }\end{array}$ & $\begin{array}{l}\text { General } \\
\text { location } \\
\text { in study } \\
\text { area }\end{array}$ & $\begin{array}{l}\text { Percent finer } \\
\text { than 0.063 } \\
\text { millimeter }\end{array}$ \\
\hline $\begin{aligned} \text { 24S/13W-27BDB01 } \\
\text {-32ACC01 }\end{aligned}$ & 130 & SE & 27 \\
23S/13W-34DBA01 & 185 & SW & 69 \\
-22DCD05 & 95 & NE & 83 \\
& 122 & NW & 73 \\
\hline
\end{tabular}

Robison (1973) computed vertical hydraulic conductivities of the dune sand that ranged from 0.25 to $2 \mathrm{ft} / \mathrm{d}$. These values were obtained by analysis of aquifer-test data that include water-level differences between closely spaced wells screened at different depths. The resulting ratios of horizontal to vertical hydraulic conductivity of the dune sand ranged up to 300 to 1 . However, trial simulations performed with the model used in the present study gave best results when a ratio of 10 to 1 was used. This ratio of horizontal to vertical hydraulic conductivity was used for all geologic units (see section "Model Calibration").

\section{SIMULATION OF GROUND-WATER FLOW}

A steady-state, ground-water-flow model that simulates the position of the freshwater-seawater interface developed by Sapik (1988) was used to construct the four-layer ground-water-flow model in the dune aquifer and adjacent deposits within the study area. The model was calibrated with annual-averaged data and used to compute steady-state heads in the dune aquifer and positions of the freshwater-seawater interface for different rates and distributions of ground-water pumpage.

\section{Model Construction}

The areal extent of the model and the location of pumped wells are shown in figure 12. The western boundary is in the Pacific Ocean beyond the expected most seaward point of freshwater discharge. Tenmile Creek is the northern boundary. A drainage divide (a no-flow boundary) forms the eastern boundary. The model's southern boundary is Coos Bay. The model's upper boundary is the water table in layer 4, and the model's lower boundary in layer 1 was assumed to be 100 feet below the bottom of the dune aquifer in the Tertiary deposits of low permeability (fig. 13). No ground water was allowed to flow through the borders of the modeled area or through the model's lower boundary. Also, no flow was allowed to cross the freshwater-seawater boundary whose position was computed by the model. This boundary is assumed to be a sharp interface, although in reality it is usually a diffuse zone. For the purpose of this report it is adequate to assume that the simulated depth to the interface approximates the depth to where the chloride concentration is $9,500 \mathrm{mg} / \mathrm{L}$ (milligrams per liter), which is one-half the concentration in seawater. A shortcoming of assuming that the freshwater-seawater boundary is a sharp interface is that water in the aquifer above the simulated interface 


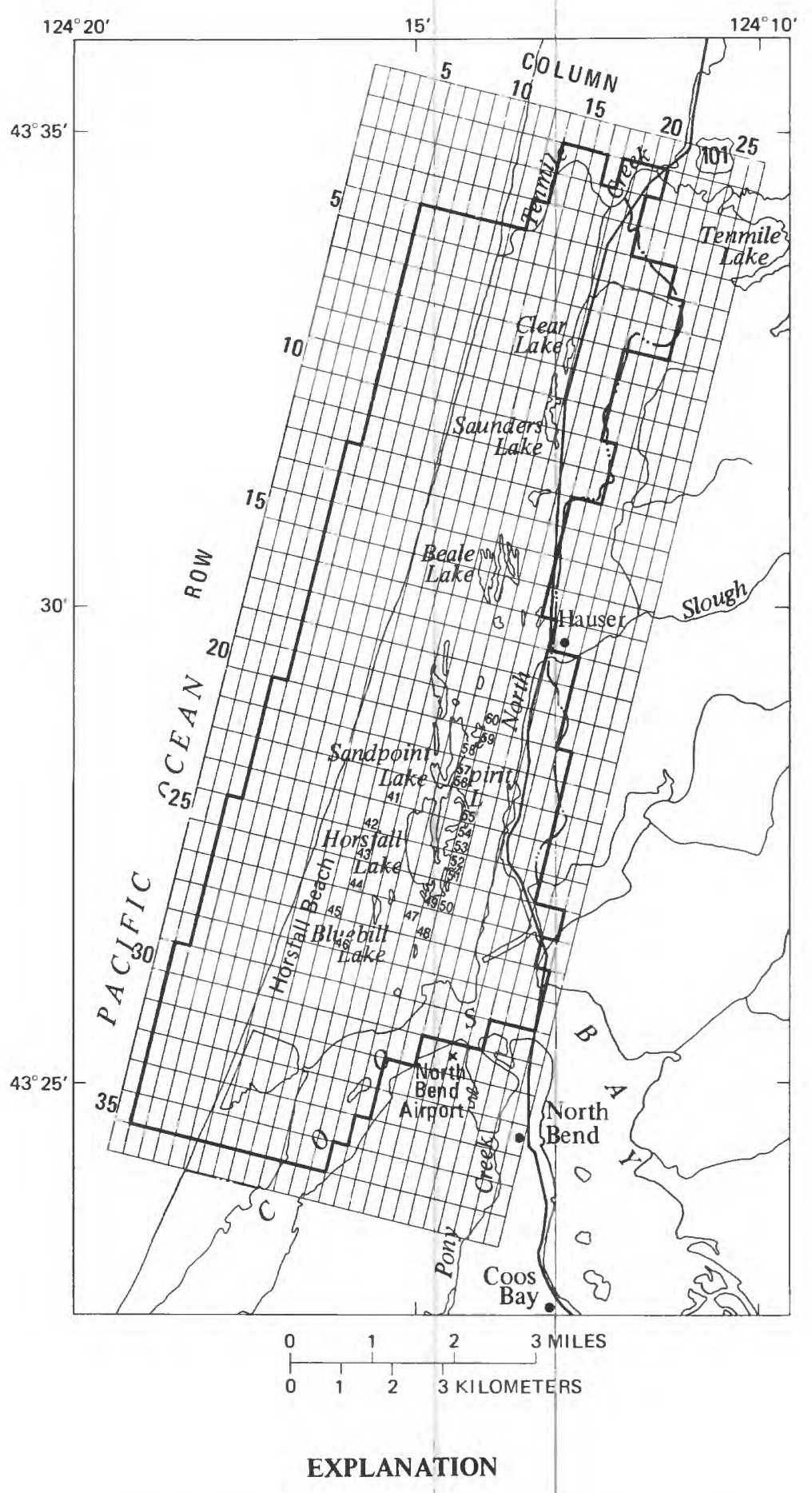

Model grid cell-Number within cell identifies the pumped-well number (see table 2)

Model boundary

Figure 12.--Model grid and location of pumped wells. 


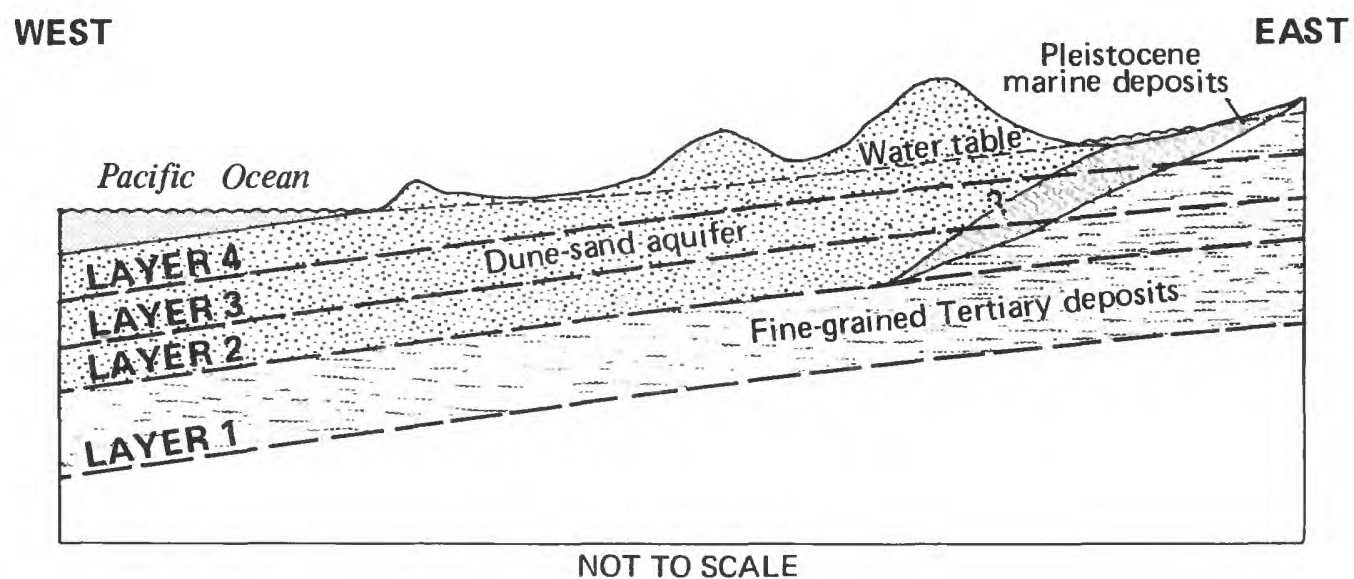

Figure 13.--Schematic geologic section through the northern part of model area showing the model layering.

is assumed to have zero chloride concentrations, whereas in reality the concentration in the diffuse zone near the interface could be as large as $9,500 \mathrm{mg} / \mathrm{L}$.

Ground water was allowed to discharge to the ocean, Coos Bay, and North Slough at rates that depend on the difference between the model-simulated head in the dune aquifer and the hydrostatic heads at the bottoms of these three saltwater bodies (fig. 14). Water was allowed also to flow between Tenmile Creek and the dune aquifer at a rate dependent on the differences between the model-simulated head in the aquifer and a specified head in the creek.

Because the lakes are formed where depressions in the land surface simply intersect the water table and are continuous with the dune aquifer (Robison, 1973), no special conditions are established at grid cells that contain lakes. Precipitation recharged the aquifer through the water-table boundary (top of layer 4) at a specified rate (fig. 15).

The vertical movement of water throughout the study area was simulated by dividing the model into four layers that are numbered from bottom to top. The three uppermost layers (layers 2, 3, and 4) consist primarily of the saturated part of the dune sand. In the northeastern part of the study area, the upper three layers include the Pleistocene marine deposits and older fine-grained deposits of Tertiary age (fig. 13). Thicknesses of these three layers are equal in a vertical section, but vary areally. The bottom layer (layer 1) consists of the uppermost 100 feet of the fine-grained Tertiary deposits.

A uniform rectangular grid was overlaid on a map of the study area to divide each layer into rectilinear volumes called cells (fig. 12). Each cell within the model is referred to by giving the row, column, and layer indices. For example, we11 60 is located in row 20 , column 18 of layer 2 or $(20,18,2)$. The model consists of 36 rows and 26 columns and contains as many as 558 active cells per layer. Cells become inactive when they are totally intruded with seawater. The width of each cell in the model is 2,000 feet and the length is 1,000 feet. 


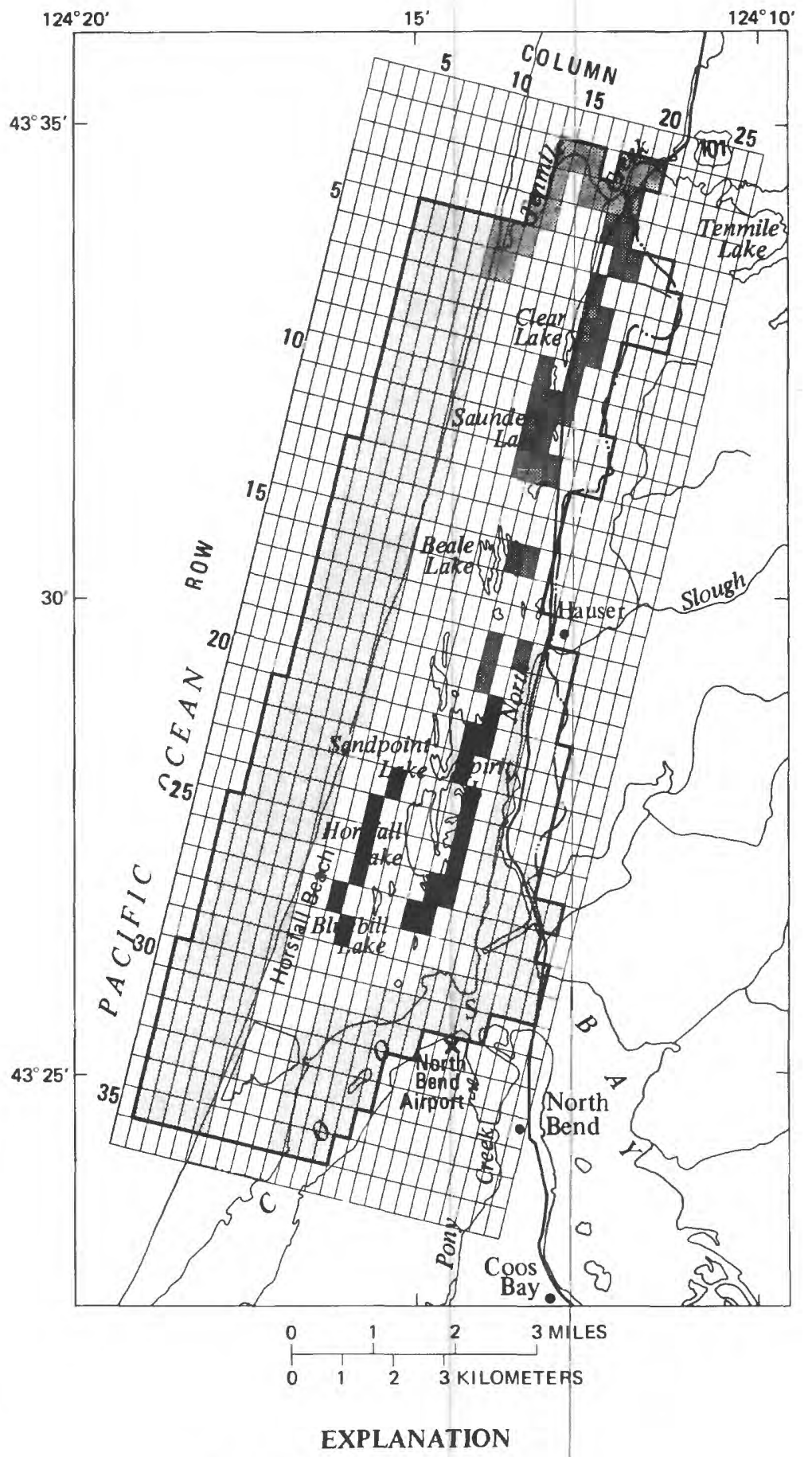

Cell discharge by type:

No discharge

Ground-water discharge to ocean, bay, or slough (layer 4)

Ground-water discharge to creek (layer 4)

Pumpage from shallow domestic wells (layer 4)

Pumpage from production wells during 1984 (layers 2, 3, and 4). Shown in table 2.

Model boundary

Figure 14.--Location and type of discharge cells used in model. 


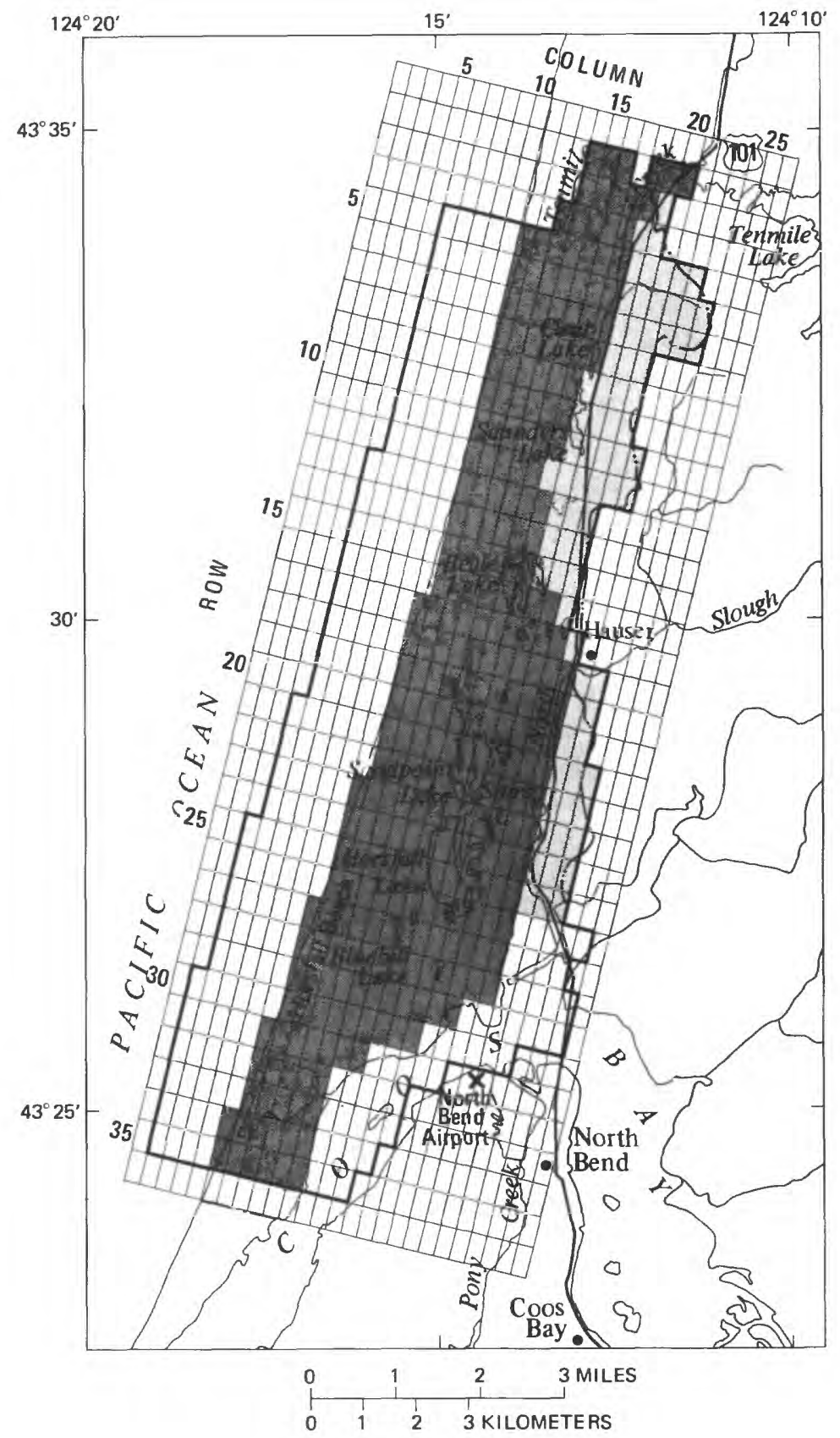

\section{EXPLANATION}

Recharge to dune-sand aquifer at a rate of $1.25 \times 10^{-7}$ cubic feet per second

Recharge to Pleistocene and Tertiary finegrained deposits at a rate of $0.1 \times 10^{-7}$ cubic feet per second

No recharge

Model boundary

Figure 15.--Rates of recharge used in model for the 1984 water year. 
Values of aquifer properties and other model-input data are specified for each cell of every layer. Required model-input data include layer transmissivities, leakance values between model layers, discharge coefficients and surface-water heads for cells that discharge to the ocean, bay, and streams, altitudes of the bottoms of the cells, recharge from precipitation, and pumpage from wells. To calculate the position of the interface, the ratio $\Delta \rho / \rho_{f}$ equal to 0.025 also is required, where $\Delta \rho$ is the density difference between the seawater and freshwater and $\rho_{f}$ is the density of freshwater.

By using finite-difference methods, the computer program solves the ground-water-flow equations to determine the ground-water heads in every cell of the model. The model also computes the position of the freshwatersaltwater interface by finding the depths where the pressure in the flowing fresh ground water equals the hydrostatic pressure in nonflowing seawater. This process is similar to the Ghyben-Herzberg principle, but this model considers the variation of head with depth as according to Hubbert (1940):

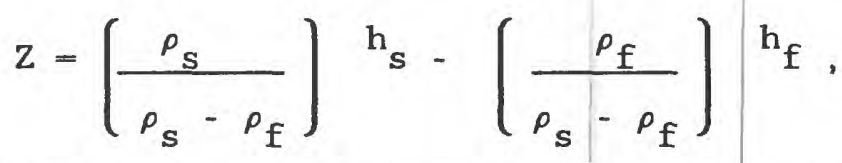

where $\mathrm{Z}$ equals the altitude of the interface, $\rho$ and $\rho_{\mathrm{f}}$ are the density of the saltwater and freshwater, respectively, and $h_{s}$ and $h_{f}$ are the saltwater heads and freshwater heads at the interface. When the sal Ewater head ( $h_{s}$ ) equals zero, the first term in equation 1 drops out and the equation becomes:

$$
\mathrm{Z}=(-40)\left(\mathrm{h}_{\mathrm{f}}\right)
$$

Each ground-water head or position of the interface simulated by the mode1 represents an average value for the volume of a cell. In this report, the distribution of these average values is referred to as the regional head distribution. The details of drawdown in head or upconing of the interface in the vicinity of a pumped well that occur within a fraction of the cell area are not computed by the model, but are reflected in the average computed cell values.

\section{Mode1 Calibration}

The steady-state numerical model was calibrated using average head data for the 1984 water year. Because of seasonal variations in recharge and pumpage, the ground-water system is never in steady state; therefore, an annual-averaged model, which is mathematically identical to a steady-state model, was used for model calibration (see for example, Prych, 1983). The calibration process consisted of making repeated calculations with the model using different values of leakage coefficients and transmissivities to determine which values of these parameters would give the best agreement between simulated and observed ground-water heads. The calibration process was an iterative one in which the transmissivities were adjusted to minimize differences between simulated and observed heads, and the leakage coefficients between layers and water bodies were adjusted to give the desired head differences in the vertical direction. This process was continued until acceptable results were obtained. 
Ideally, the model also should be calibrated to properly simulate the depth to the freshwater-seawater interface. However, because only two wells were deep enough to have elevated chloride concentrations, calibration for the interface position was limited mostly to assuring that the depth to the interface was greater than the depth of existing wells.

The range of pumping rates from wells used for model calibration are given in figure 16, with exact rates shown in Appendix A. These pumping rates were obtained from the annual-averaged pumping rate for each of the production wells as given in table 2. The location of the cells containing these wells are identified in figure 14. The quantity pumped from each layer of the model was assumed to be proportional to the percentage of screened interval open to the layer. Cells containing one or more domestic wells are also shown in figure 14. The consumptive use of water from domestic wells in each of these cells was computed by multiplying the number of wells in each cell (estimated by King Phelps, Coos Bay-North Bend Water Board, oral commun., 1987) by 83 gal/d; see section on "Ground-Water Withdrawals." The total consumptive use from the 143 domestic wells was $14,000 \mathrm{gal} / \mathrm{d}\left(0.022 \mathrm{ft}^{3} / \mathrm{s}\right)$. Most of these wells are shallow sand points driven close to the lakes and are assumed to have been completed in the uppermost layer of the model.

Recharge was applied over the uppermost layer (layer 4) of the model at the rates shown in figure 15 . These rates were computed as described in the section entitled "Recharge and General Hydrology." The rate applied to the dune aquifer, which was computed using water balance equations, is 47 in./yr. The amount of recharge applied to the northeastern area, where fine-grained deposits are at the land surface, was 10 percent of the precipitation for the 1984 water year ( 7.5 inches).

Ranges for the bottom altitude of the cells are given in figure 17 and the actual altitudes are given in Appendix A. Bottom altitudes of cells in the upper three layers, where they contain the dune aquifer, were obtained using Robison's (1973) maps of water-table altitude and dune aquifer thickness.

Only 100 feet of Tertiary deposits beneath the dune aquifer are simulated by the model; consequently, the bottom of the fourth layer is uniformly 100 feet below the third layer. Although the Tertiary deposits probably exceed 1,000 feet in thickness, little of the ground-water flow is expected to be flowing in these nearly impermeable deposits. Sensitivity tests with the model showed that increasing the transmissivity of the fourth layer by a factor of 10, which is equal to modeling 1,000 feet of thickness, resulted in head changes within the dune aquifer of about 1.5 feet.

The surface-water-body heads ( $h_{s}$ ) for Tenmile Creek (table 4) were obtained from a topographic map. For cells that discharge to seawater bodies, the model-computed values of $h$ are computed by multiplying the depth below sea level to the top of the cells by the ratio $\Delta \rho / \rho_{f}$ equal to 0.025 . This ratio is used also in computations of the freshwater-seawater interface position.

Ranges of aquifer transmissivities, leakage coefficients between model layers, and discharge coefficients for cells that discharge to the ocean, bay, and streams, as obtained through model calibration, are given in figures 18 , 19, and 20; actual values are shown in Appendix A. 


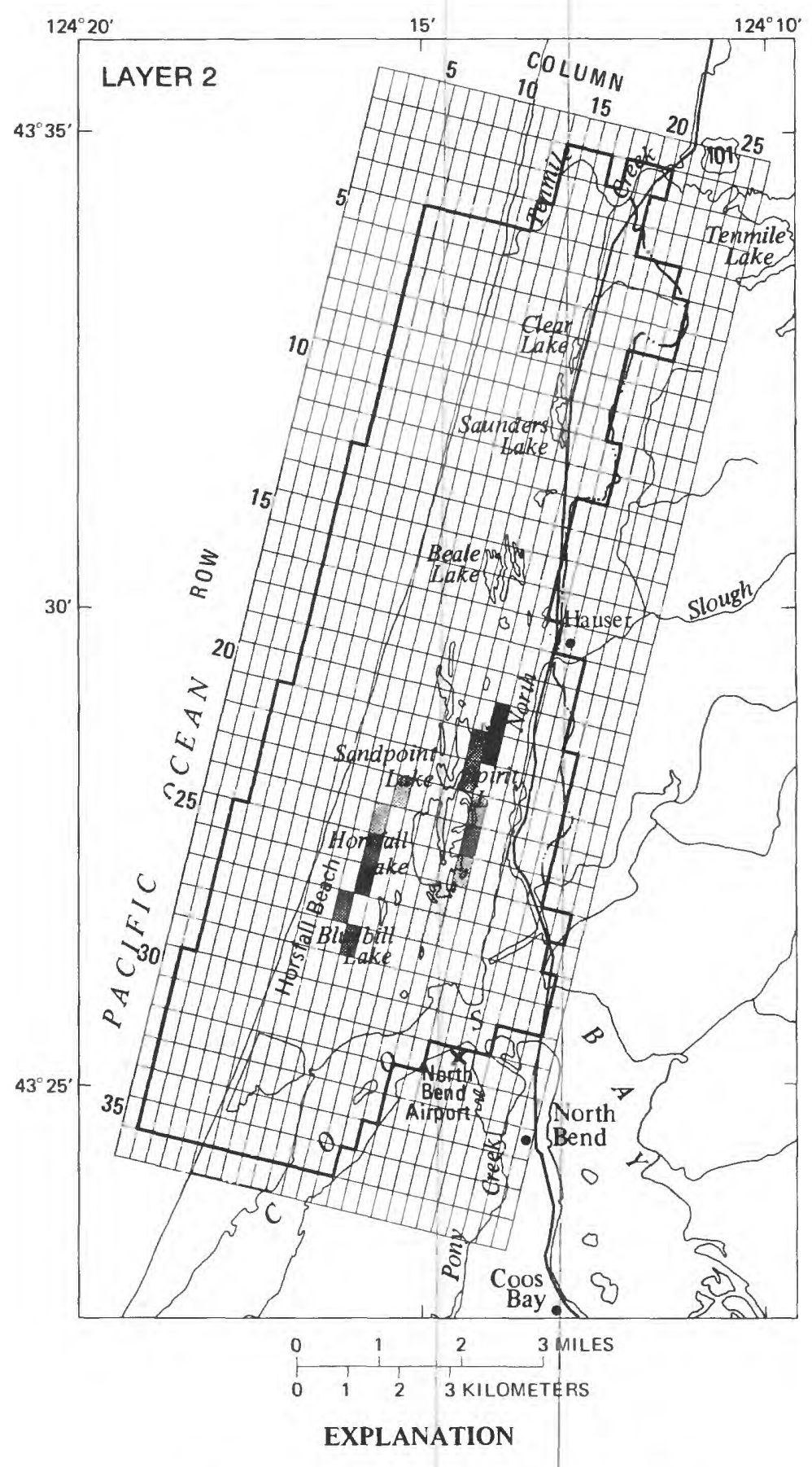

Model-input well pumpage-In cubic feet per second

0

0.0001 to 0.0099

0.01 to 0.099

0.1 to 0.4

More than 0.4

Model boundary

Figure 16.--Model-input well pumpage for model layers. 


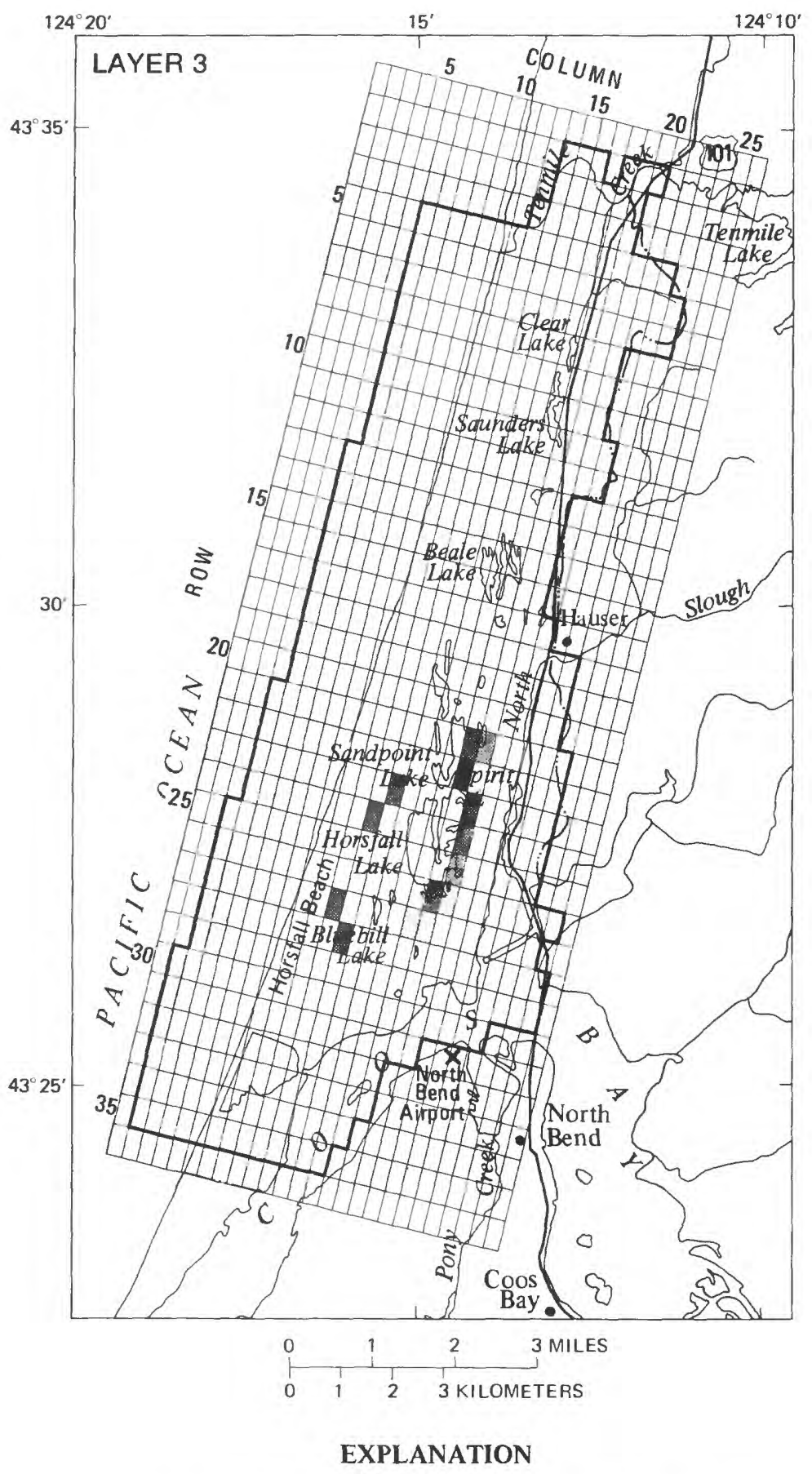

Model-input well pumpage-In cubic feet per second

0

0.0001 to 0.0099

0.01 to 0.099

0.1 to 0.4

More than 0.4

Model boundary

Figure 16.--Model-input well pumpage for model layers--Continued. 


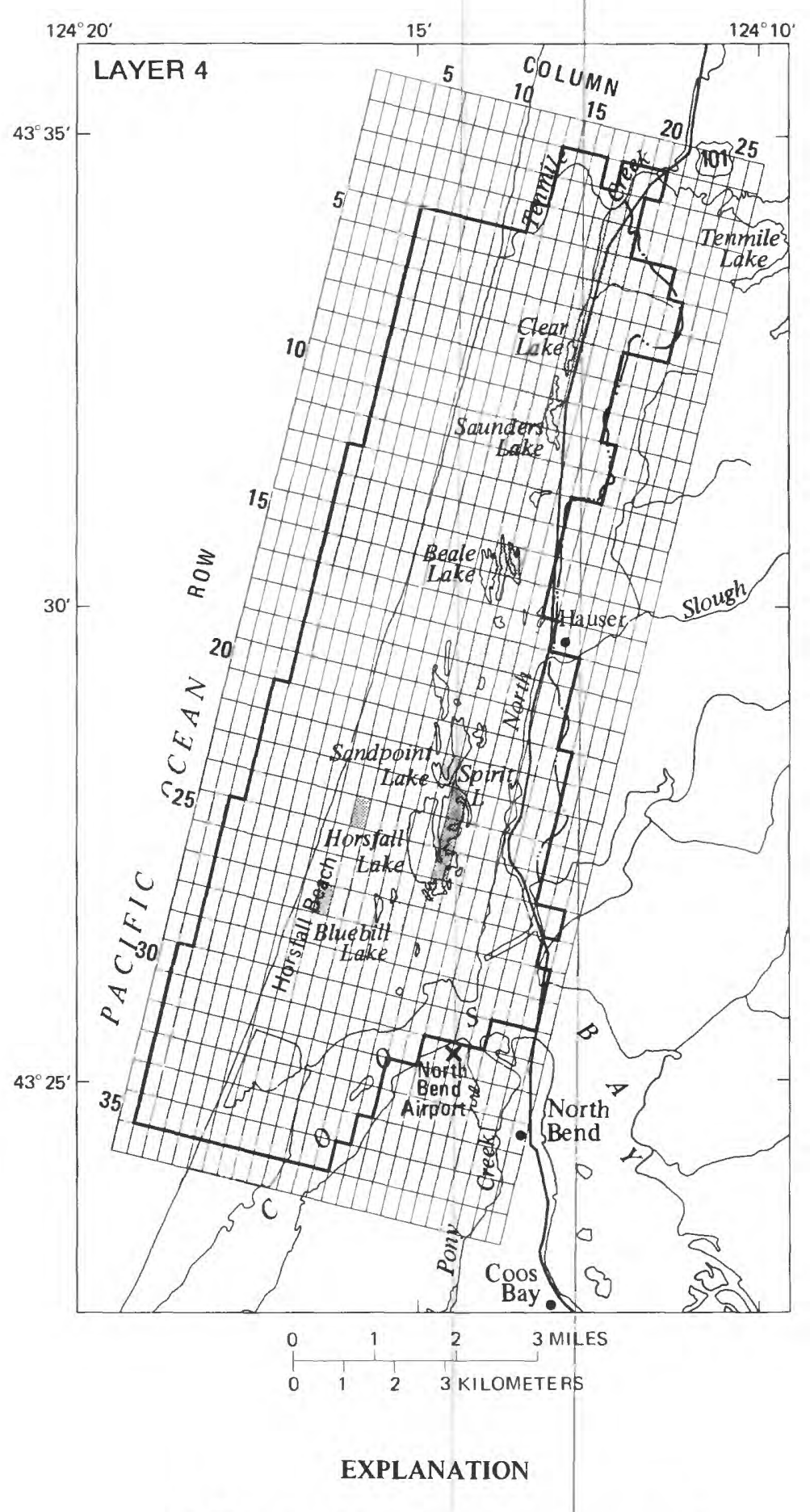

Model-input well pumpage-In cubic feet per second

0

D 0.0001 to 0.0099

0.01 to 0.099

Model boundary

Figure 16.--Model-input well pumpage for model layers--Continued. 


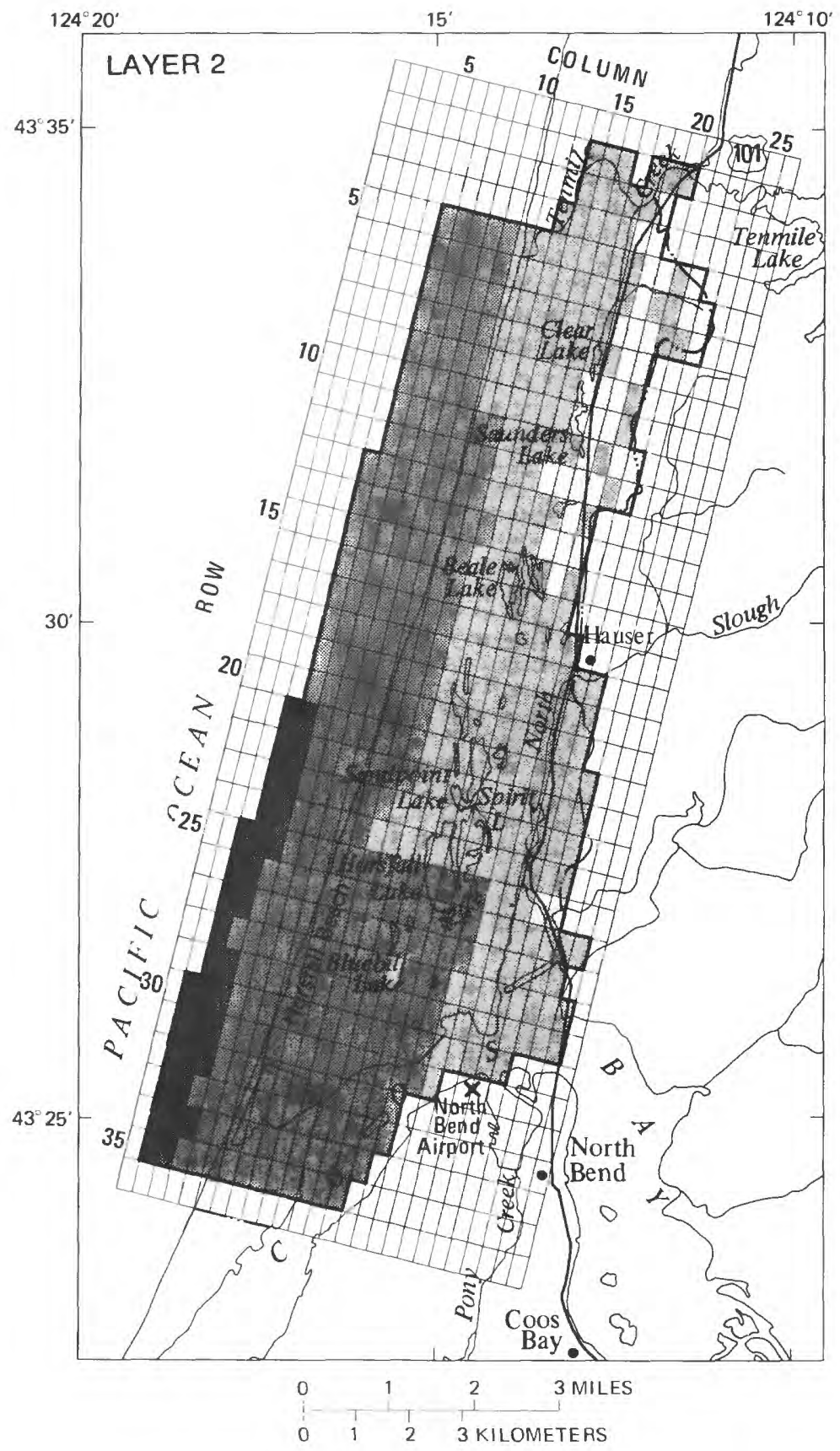

EXPLANATION

Bottom altitude of model layers-In feet below sea level

Less than 0

0.1 to 99.9

100 to 200

More than 200

Model boundary

Figure 17.--Bottom altitudes of model layers. 


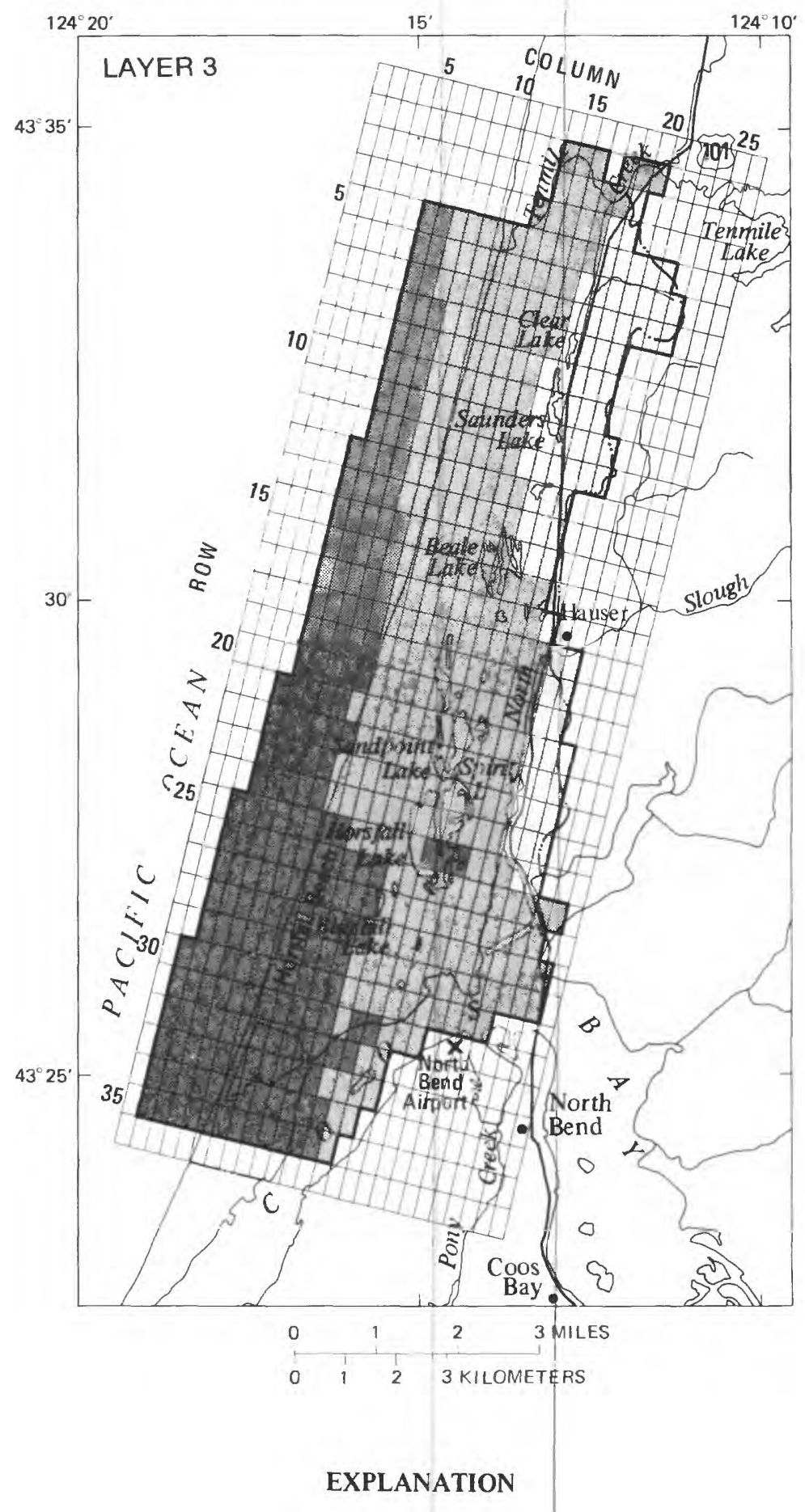

Bottom altitude of model layers-In feet below sea level Less than 0

0.1 to 99.9

100 to 200

More than 200

Model boundary

Figure 17.--Bottom altitudes of model layers--Continued. 


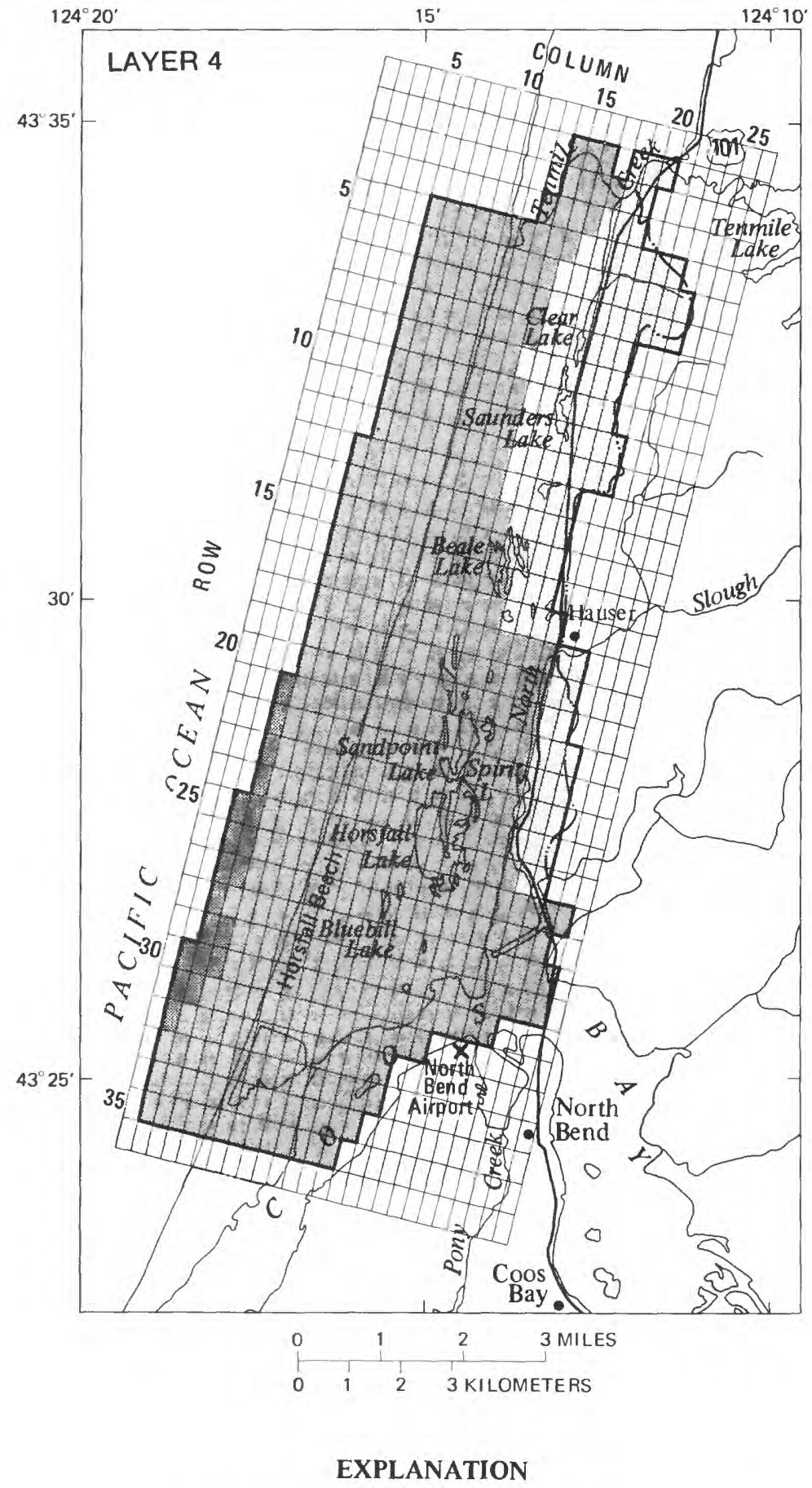

Bottom altitude of model layers-In feet below sea level Less than 0 0.1 to 99.9 100 to 200 Model boundary

Figure 17.--Bottom altitudes of model layers--Continued. 


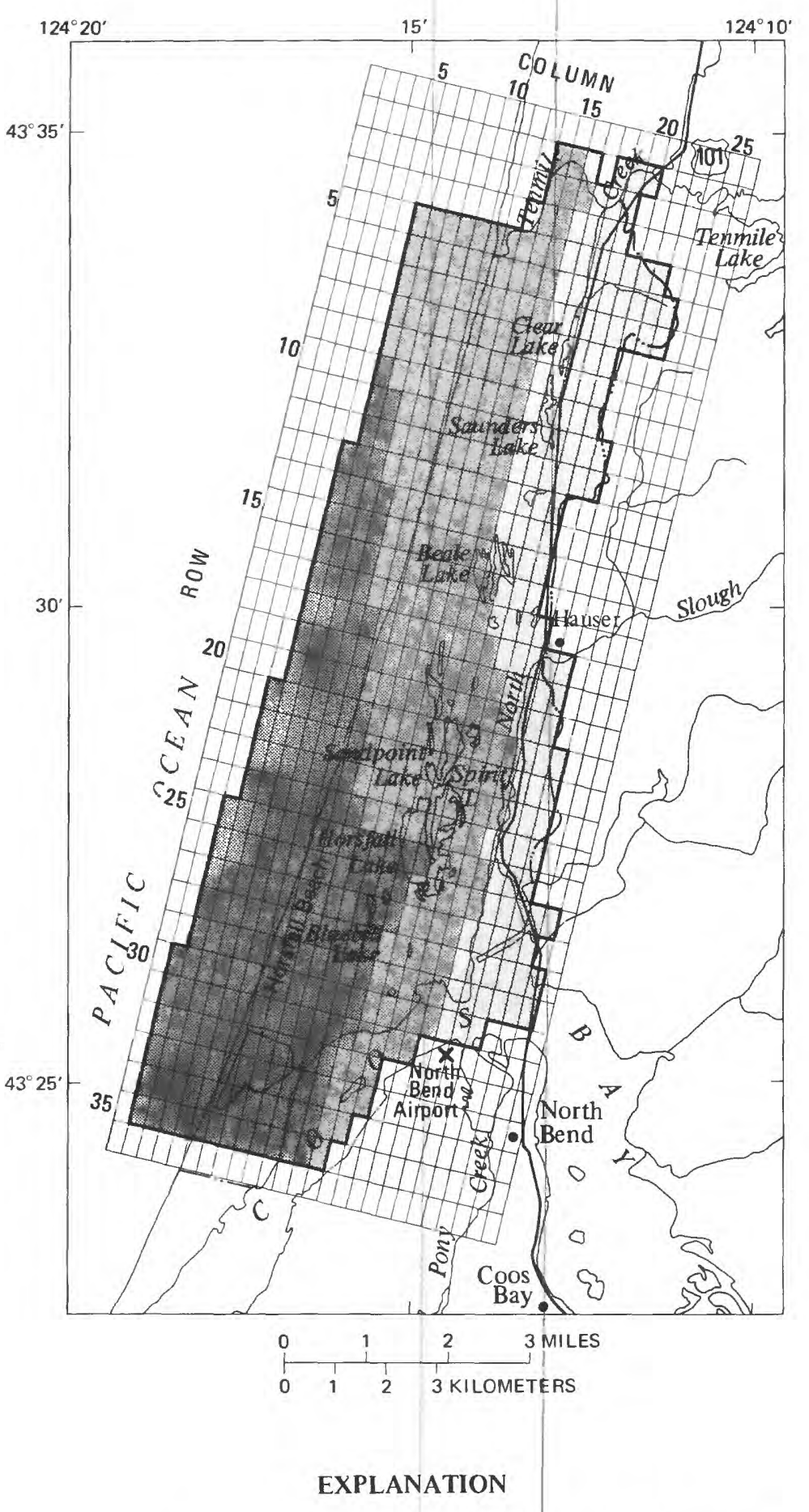

Transmissivities for dune-sand aquifer layers-Based on simulation, in $1 \times 10^{-2}$ feet squared per second

Less than 1.0

1.0 to 4.0

More than 4.0

- Model boundary

Figure 18.--Simulated transmissivities for dune-sand aquifer layers. 


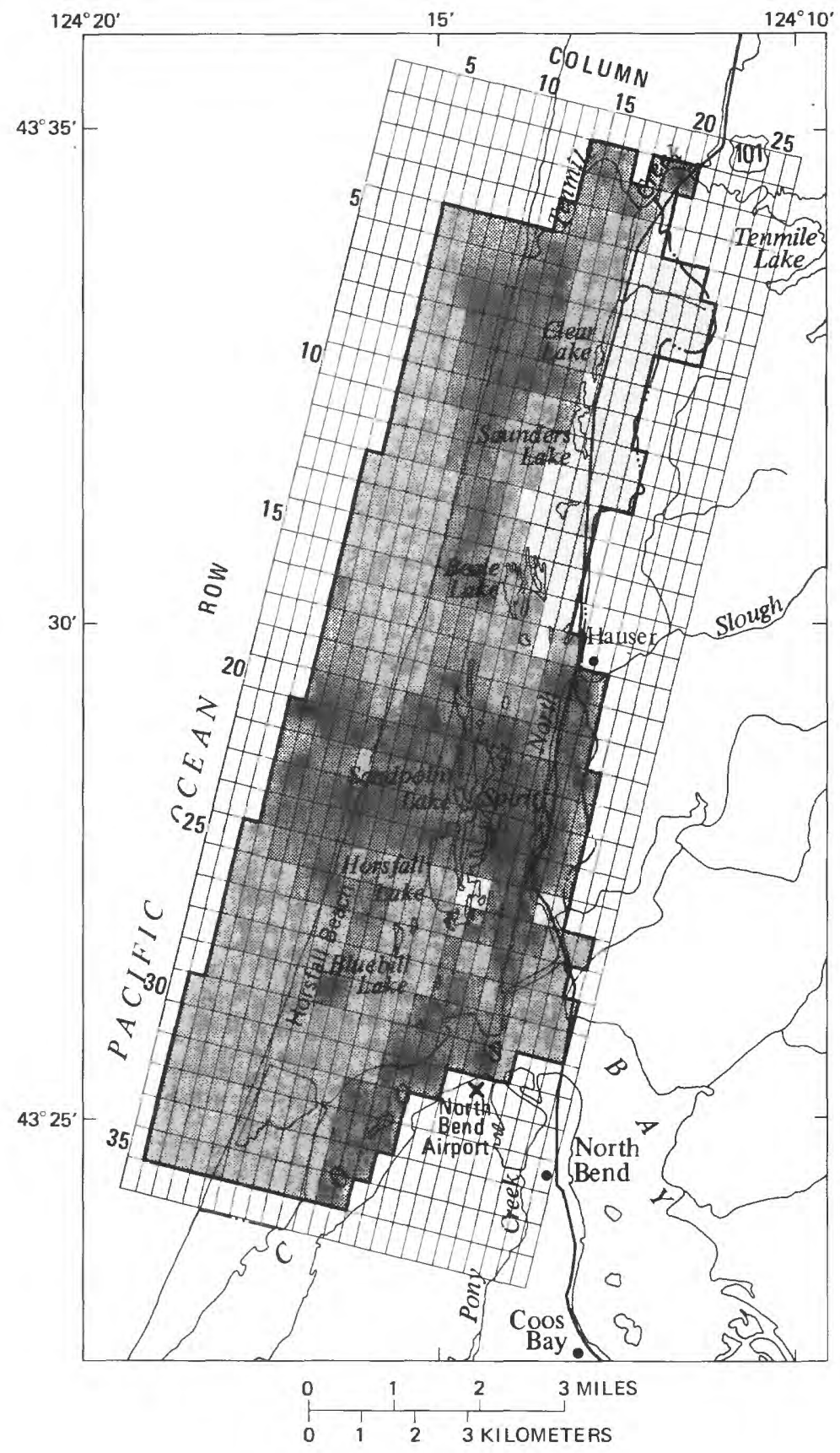

\section{EXPLANATION}

Leakage coefficients between model layers 2 and

3 , and layers 3 and 4-Based on simulation,

in $1 \times 10^{-5}$ second $^{-1}$

Less than 0.1

(2) 0.1 to 0.2

More than 0.2

Model boundary

Figure 19.--Simulated leakage coefficients between model layers 2 and 3 and layers 3 and 4. 


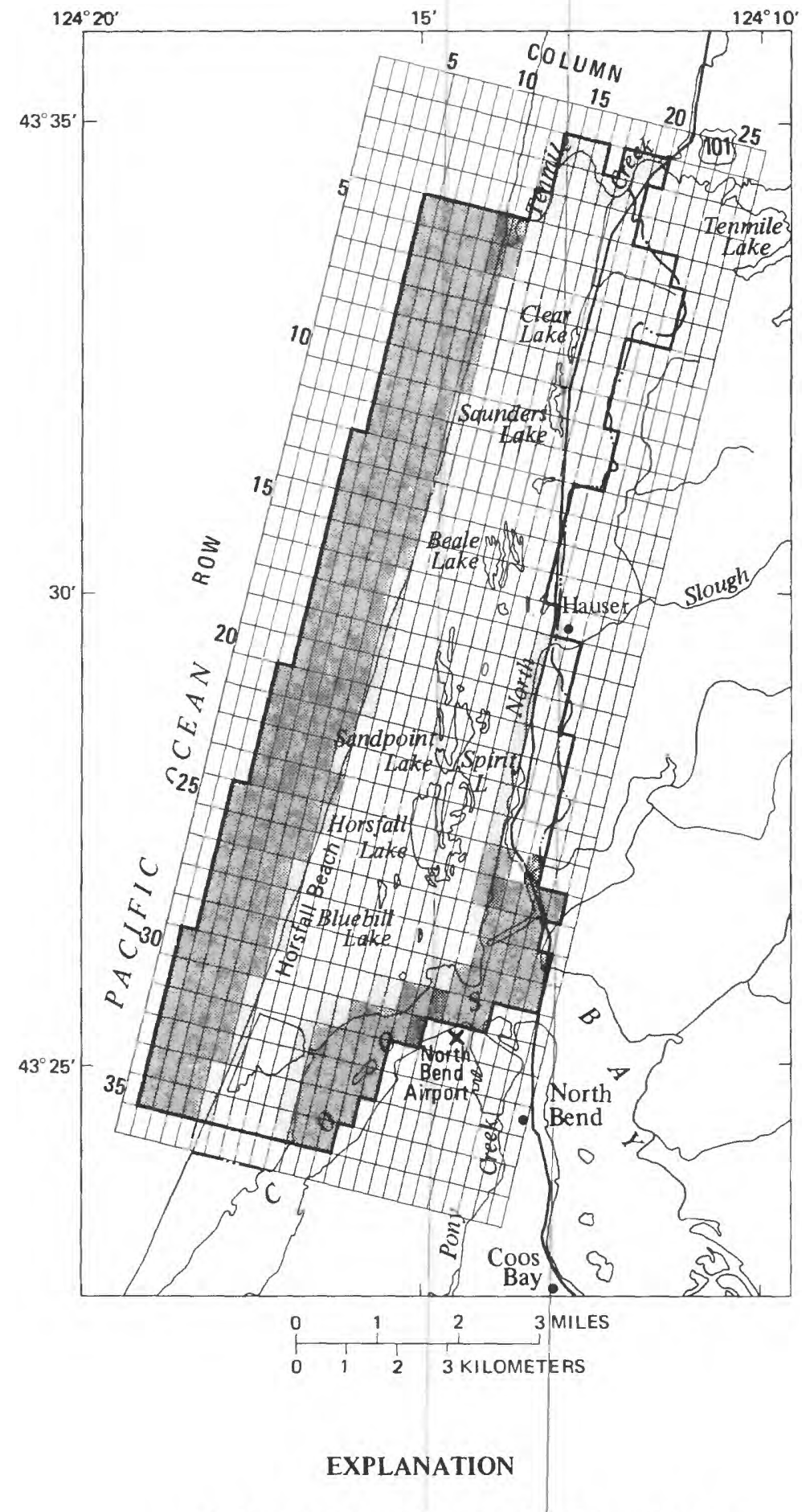

Leakage coefficients for cells that discharge to the ocean-Based on simulation, in feet squared per second

\section{0}

0.1 to 0.499

0.5 to 0.999

Equal to or greater than 1.0

Model boundary

Figure 20.--Simulated leakage coefficients for cells that discharge to the ocean. 
Initial estimates of transmissivities of the dune-sand aquifer were obtained from the transmissivity map given by Robison (1973) (see section "Hydraulic Properties of Geologic Units"). The upper three layers of the model contain mostly this aquifer. Initial estimates of transmissivities of the upper three layers of the model where they consist of Pleistocene and fine-grained Tertiary deposits were obtained by multiplying layer thicknesses by the horizontal hydraulic conductivity given earlier. During the calibration process, transmissivities of all cells in the upper three layers were varied uniformly by using a common multiplier. As mentioned in the earlier section "Hydraulic Properties of Geologic Units," the transmissivities of the three upper layers in the calibrated model are 28 percent higher than originally estimated. The resulting horizontal hydraulic conductivities, obtained by dividing calibrated transmissivities by layer thickness, ranged from $0.314 \times 10^{-3}$ to $1.45 \times 10^{-3} \mathrm{ft} / \mathrm{s}$ for the dune aquifer and was $0.28 \times 10^{-3} \mathrm{ft} / \mathrm{s}$ for the Pleistocene and other fine-grained deposits in the upper three layers.

A uniform transmissivity of the lower layer (layer 1), which consists entirely of fine-grained Tertiary deposits, was obtained by multiplying the estimated horizontal hydraulic conductivity $(2 \times 10-6 \mathrm{ft} / \mathrm{s})$ by the layer thickness (100 feet). Decreasing the transmissivity by a factor of 10 increased simulated heads by about 0.1 foot. Increasing the initial estimates by a factor of 10 decreased heads by 1.5 feet. In all of the three tests the simulated heads could be made to agree with the observed heads to the same degree of accuracy by

Table 4.--Mode1-input surfacewater heads for Tenmile Creek in layer 4

\begin{tabular}{ccc}
\hline & Model & $\begin{array}{c}\text { Head, } \\
\text { in feet } \\
\text { above }\end{array}$ \\
\cline { 1 - 2 } Row & Column & leve1 \\
\hline & 14 & 5 \\
2 & 14 & 6 \\
2 & 15 & 6 \\
2 & 16 & 10 \\
2 & 18 & 11 \\
2 & 19 & 12 \\
2 & 20 & 5 \\
3 & 14 & 7 \\
3 & 16 & 8 \\
3 & 17 & 9 \\
3 & 18 & 3 \\
4 & 13 & 4 \\
4 & 14 & 3 \\
5 & 11 & 3 \\
5 & 12 & 3 \\
5 & 13 & 3 \\
6 & 11 & 3 \\
6 & 12 & \\
\hline
\end{tabular}


adjusting the hydraulic properties of the dune aquifer within acceptable limits. Because there were no observed head values in the lower layer for use in calibrating values of hydraulic conductivity, the initial estimate of hydraulic conductivity of the fine-grained Tertiary deposits $(2 \times 10-6 \mathrm{ft} / \mathrm{s})$ was used in the calibrated model.

Leakage coefficients for flow between model layers and for discharge to the ocean, bay, and streams were computed using equations from Sapik's model (1988). All cells discharging to the surface-water bodies are in the uppermost layer (layer 4). The area (A) used to represent a stream is the mapped area of the stream or lake within the cell. When the surface-water body is the ocean, bay, or slough, the area is ysually the entire horizontal area of the cell. However, for cells along the shoreline, whose upper surfaces were partly above and partly below sea level, half of the cell areas were used. Vertical hydraulic conductivities for all layers were estimated by dividing the horizontal hydraulic conductivities by a common factor, and during model calibration, all leakage coefficients were varied uniformly by using a common multiplier. This procedure is equivalent to varying all vertical hydraulic conductivities uniformly. Model calibration showed that the best ratio of horizontal to vertical hydraulic conductivity is 10; however, because most of the water-level data are for the dune aquifer, this ratio may be representative of only the dune aquifer.

Annual-average water levels in wells throughout the dune aquifer and contours of simulated water levels in the model's upper layer (layer 4) for the calibration period are shown in figure 21. The root-mean-squared difference between all observed and simulated water levels is 3.5 feet. Simulated ground-water levels below Horsfall and Spirit Lakes are about 3 feet lower than the observed water level in the lakes (fig. 21). This is consistent with the fact that ground water is pumped into the lakes to maintain their levels. Although ground water is also pumped into Sandpoint Lake, the simulated water level is equal to or slightly higher than the observed water level in the lake. Simulated ground-water levels below Bluebill and Beale Lakes equal or slightly exceed the observed water levels in the lakes, because water levels in these lakes are not artificially maintained.

The maximum landward extent of the simulated interface at the bottom of the dune aquifer (layer 2) is shown in figure 22. The simulated interface is generally within 500 feet of the coastline, except in the south where the interface is predominantly landward of the shoreline. Three generalized hydrogeologic sections B-B', C-C', and D-D' (locations in fig. 23) show the simulated position of the interface in the vicinity of the production wells (fig. 24). The position of the simulated freshwater-seawater interface on figure 22 indicates the maximum landward extent of a11 points also shown on section B-B' (fig. 24). The interface, which ranges from sea level to approximately 1,150 feet below sea level, is shallowest near the coast and is deepest inland where ground-water heads are highest. The simulated position of the freshwater-seawater interface is below the bottom of all wells during steady-state simulation. This is to be expected because observed chloride concentrations in these wells were less than $45 \mathrm{mg} / \mathrm{L}$ (G. C. Bortleson, U.S. Geological Survey, written commun., 1988). By comparison, the chloride concentration at the interface is assumed to be $9,500 \mathrm{mg} / \mathrm{L}$. The only available data with which simulated depths to the interface can be compared are reported by Dobberpuhl and others (1985). They give depths and chloride 


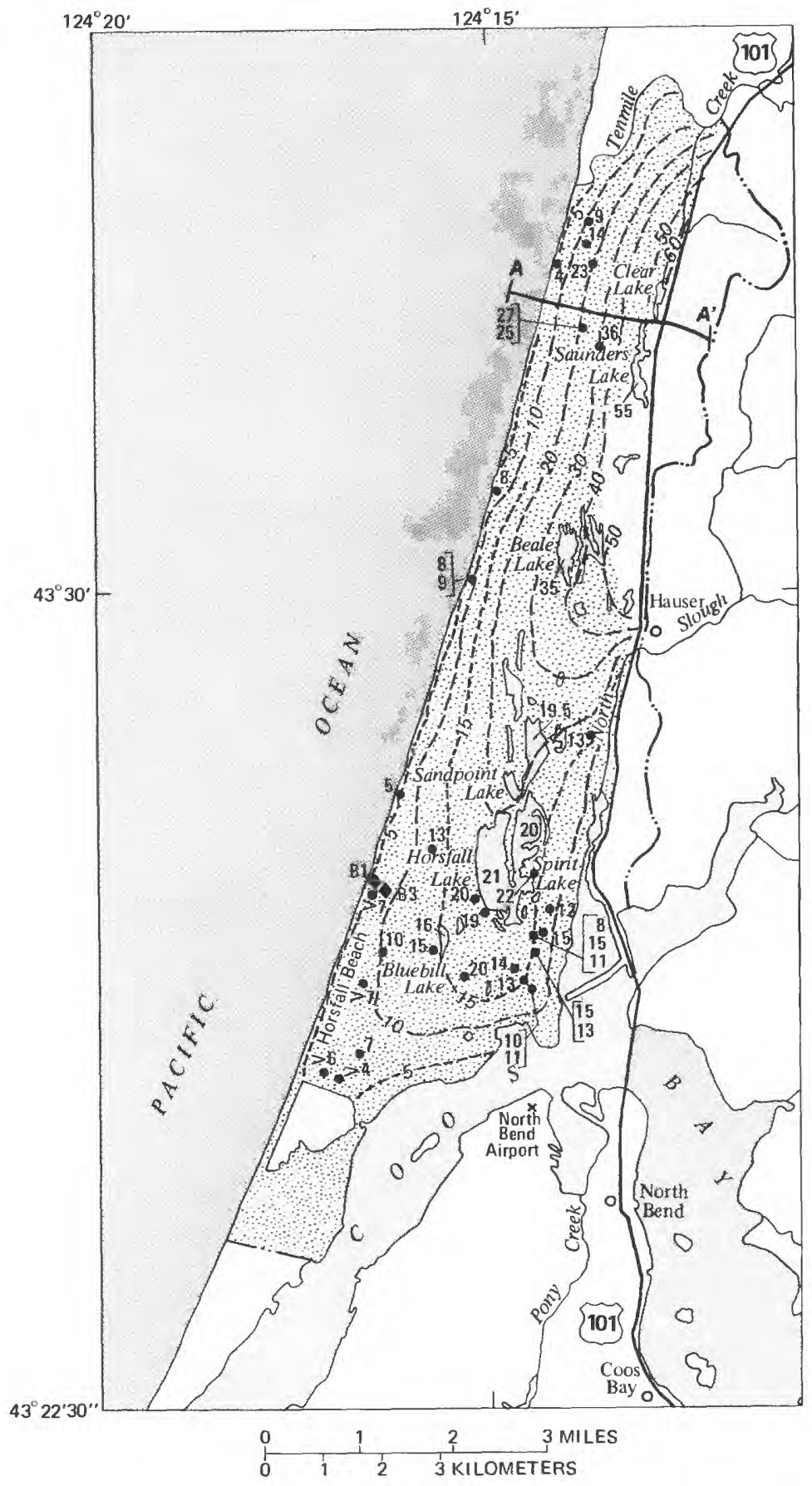

\section{EXPLANATION}

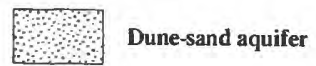

Pleistocene and fine-grained Tertiary deposits

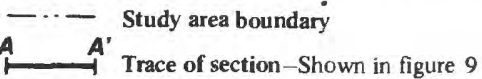

- -30-- Simulated water-level contour-Shows altitude of water level. Contour interval 5 and 10 feet. Datum is sea level.

13

Well location-Number is altitude of observed water level, in feet above sea level. Grouped numbers indicate multiple data. $>$ indicates greater than value given.

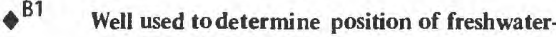
seawater interface

21 Lake level-Number shown is altitude of water level, in feet above sea level.

Figure 21.--Average observed water levels in wells and lakes, and contours of the simulated water levels in the upper layer of the model in the dune aquifer for the 1984 water year. 


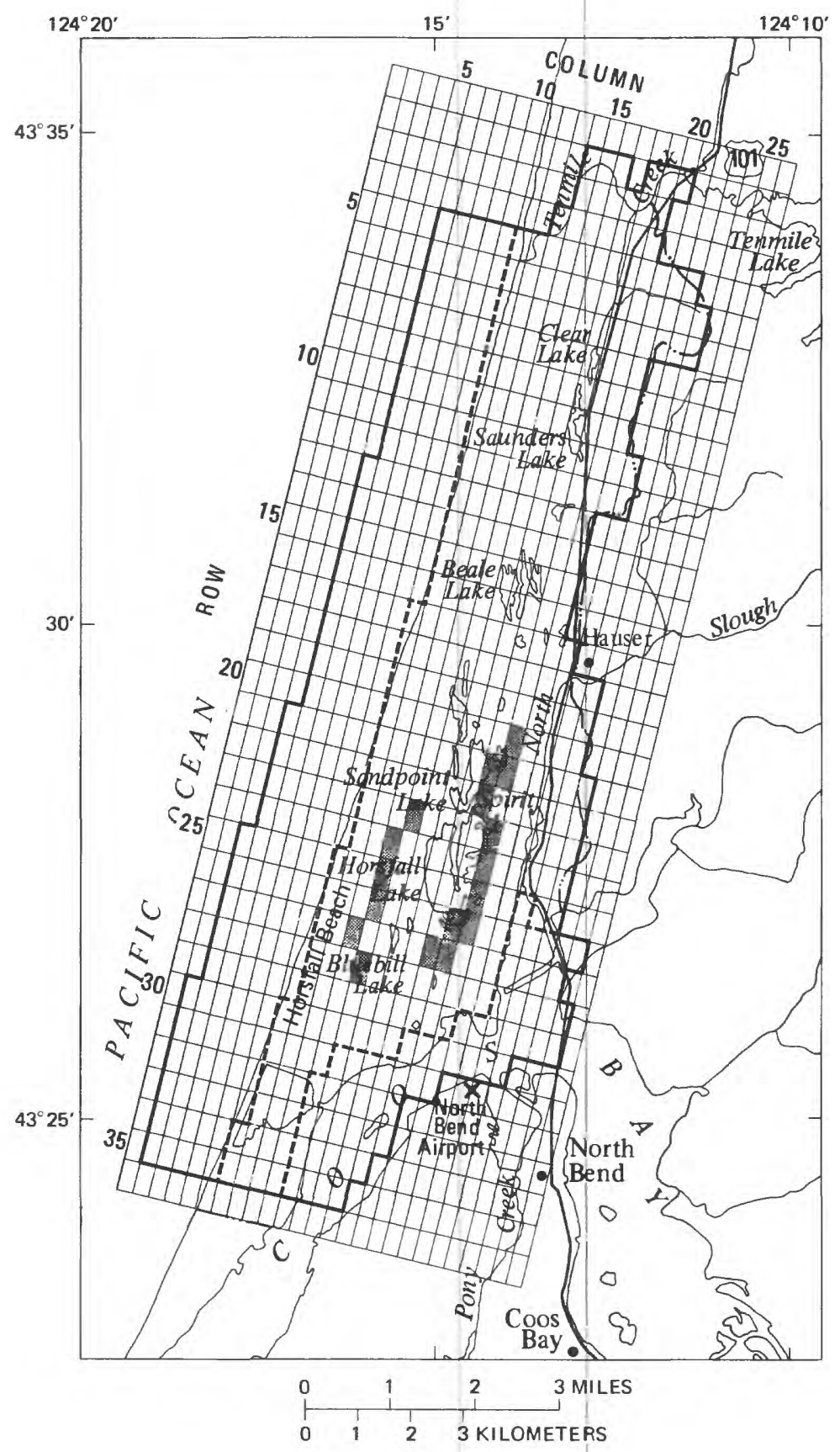

EXPLANATION

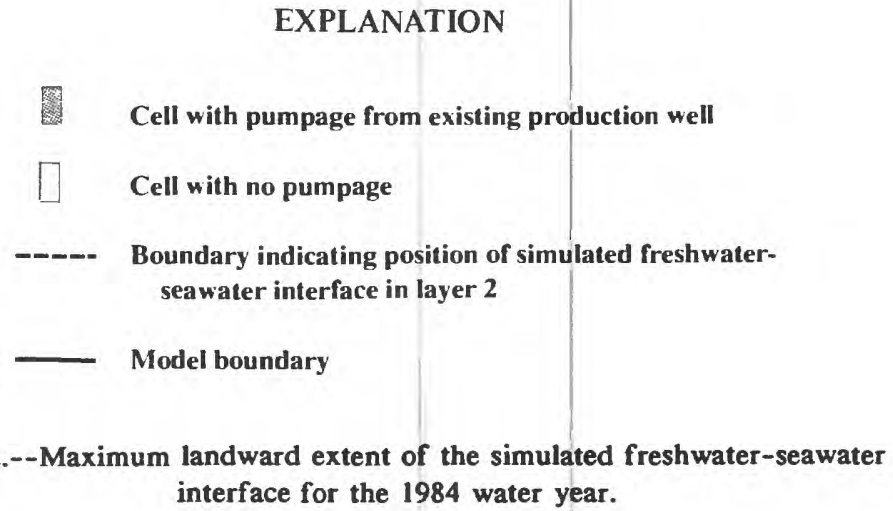




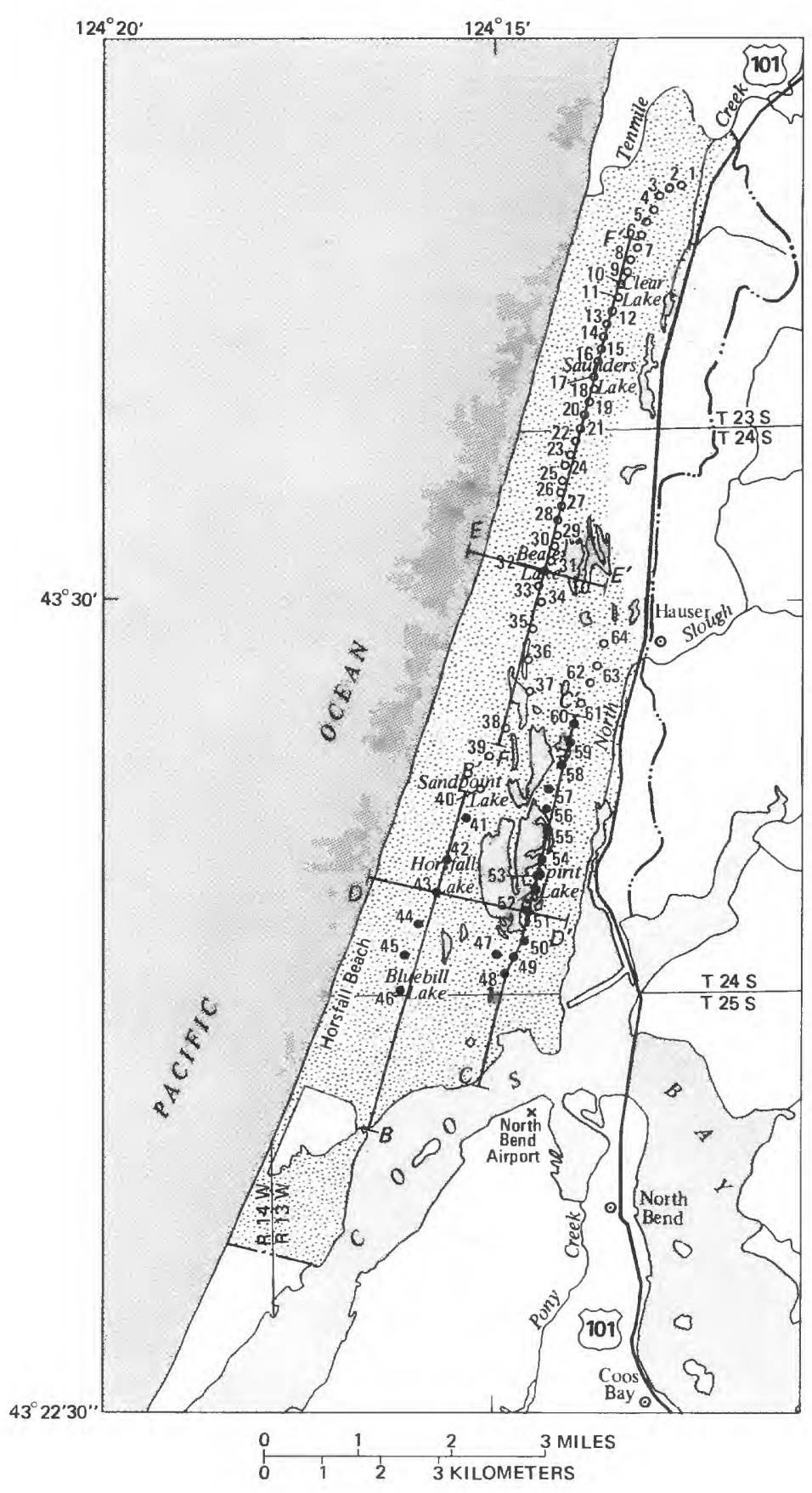

\section{EXPLANATION}

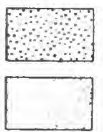

Dune-sand aquifer

Pleistocene and fine-grained Tertiary deposits

- -. Study area boundary

$\stackrel{B}{B^{\prime}}$ Trace of section-Shown in figures 24,31 , and 34

-52 Existing production well-Number indicates Water Board's production well in $\mathbf{1 9 8 4}$ (shown in Table 2).

$0^{22}$ Proposed production well-Number indicates original location proposed by the Water Board.

Figure 23.--Location of generalized hydrogeologic sections. 


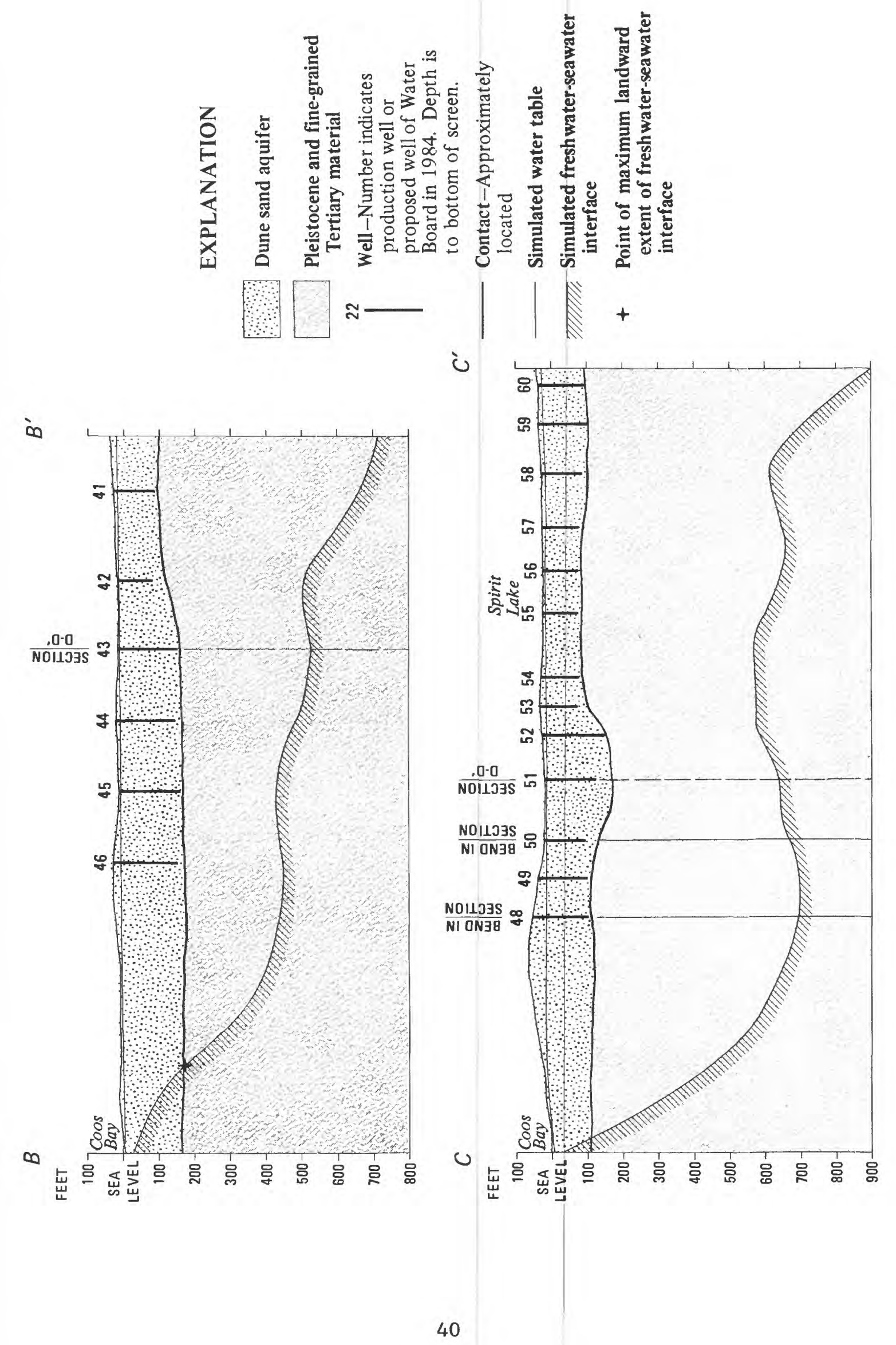




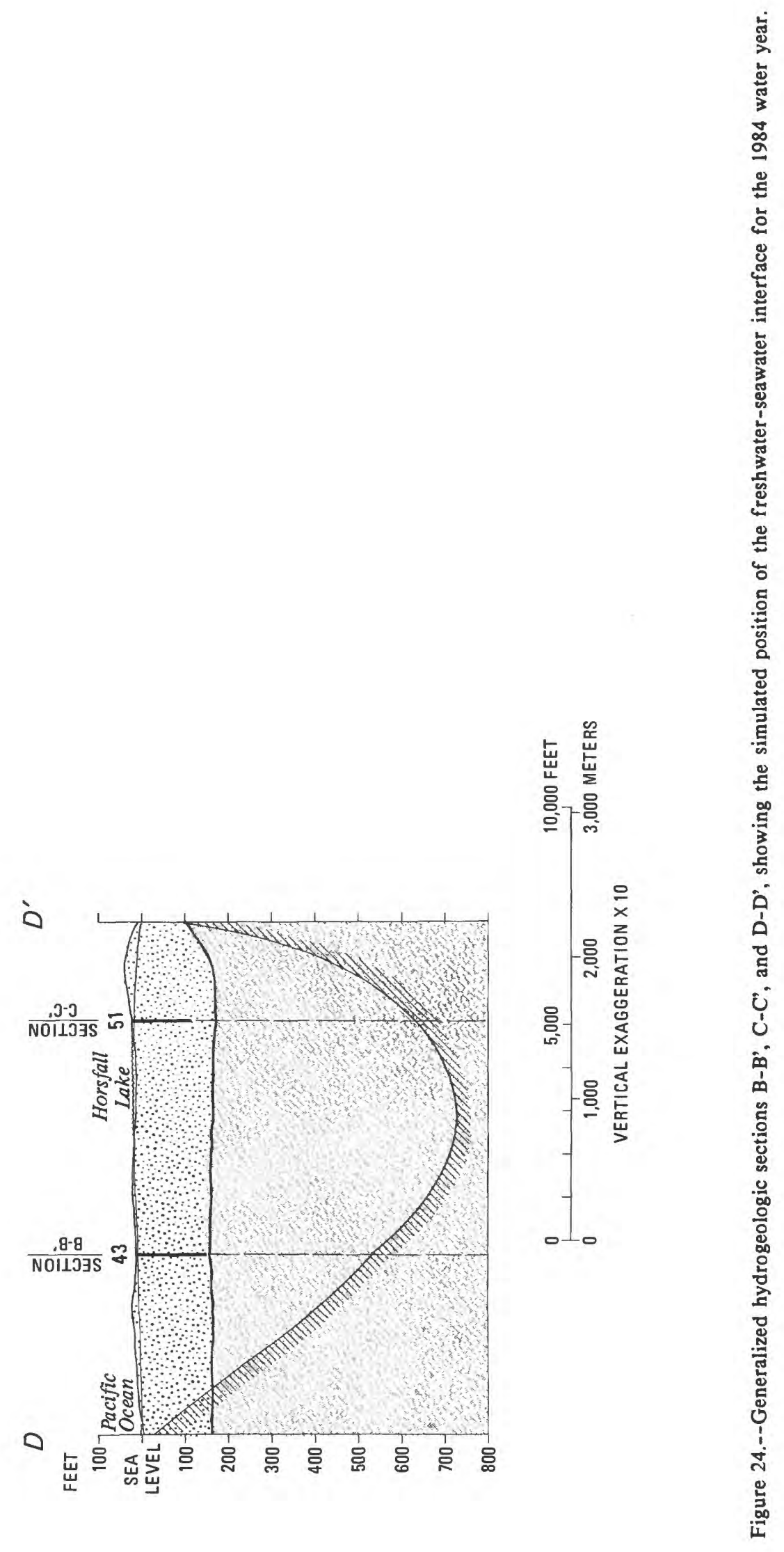


concentrations in two coastal wells near Horsfall Beach (B1 and B3; fig. 21). At well B1, which has a depth of 194 feet and a chloride concentration of $8,100 \mathrm{mg} / \mathrm{L}$, the simulated depth to the interface was 175 feet. At we11 B3, which has a depth of 171 feet and a chloride concentration of $2,900 \mathrm{mg} / \mathrm{L}$, the simulated depth to the interface was 317 feet.

\section{APPRAISAL OF SEAWATER UPCONING}

Just as there is a local cone of depression in ground-water level around a pumped well, there also can exist a local upconing of seawater beneath a pumped well. Upconing is a local rise of the freshwaterseawater interface beneath a pumped wel1. Because local upconing can occur within a fraction of the area represented by a model cell, and the model simulates average altitudes of the interface over the area of a cel1, the model does not compute the maximum altitude of the seawater cone beneath a pumped we11. Therefore, methods were devised for (1) determining if a local seawater cone beneath a pumped well will rise into the dune aquifer, and (2) estimating the fraction of seawater in water pumped from a well.

\section{Critical Pumpage}

Bennett and others (1968) developed a method for computing a maximum rate at which water can be withdrawn from a well in a deep homogenous aquifer without causing seawater to be drawn up into the well (upconing). The maximum rate is referred to as the critical pumping rate $\left(Q_{c}\right)$ and can be estimated using a graph of dimensionless variables given by Bennett and others (1968) and reproduced by Reilly and others (1987). Because the wells are located in the dune aquifer and the freshwater-seawater interface is believed to be located in the underlying fine-grained Tertiary deposits, this method cannot be applied rigorously to the problem being studied. However, the method was used to estimate whether the local seawater cone would rise above the top of the fine-grained Tertiary deposits (bottom of dune-sand aquifer).

Bennett and others (1968) defined a dimensionless maximum permissible discharge function (DMPD), which can be solved for the critical discharge:

$$
\mathrm{Q}_{\mathrm{c}}=(\mathrm{DMPD}) \mathrm{k}_{\mathrm{x}}\left(\mathrm{h}_{\mathrm{o}}\right)^{2} \Delta \rho / \rho_{\mathrm{f}},
$$

where $h$ is the thickness of freshwater between the water table and the interface with no pumping.

Equation 3 was used to compute critical pumpage for a hypothetical shallow well completed in the upper part of, and drawing water only from, the fine-grained Tertiary deposits. Therefore, the hydraulic conductivity of the fine-grained deposits was used in equation 3 . $h$ was chosen to be the distance between the water|level in the upper mode1 layer and the interface as simulated with pumping. A value of DMPD (0.4) was obtained from figure 12 of Bennett and others (1968) by using a dimensionless flownet constant (DFC) of 0.1 , which was the minimum computed value for all wells, and a fractional altitude of the screen bottom of 0.35 , which was exceeded at all but two wells. 
To estimate whether the local seawater cone could rise into the dune-sand aquifer beneath a pumped well, the value calculated for $Q_{c}$ was compared to the vertical flow $\left(Q_{2}\right)$, which is flow from a cell in the fine-grained deposits to the overlying cell in the dune-sand aquifer.

$\mathrm{Q}_{\mathrm{a}}$ can be computed using the equation

$$
\mathrm{Q}_{\mathrm{a}}=\mathrm{K}_{\ell} \mathrm{A}\left(\mathrm{h}_{1}-\mathrm{h}_{2}\right) \text {, }
$$

where $h_{1}$ and $h_{2}$ are the simulated heads in model layers 1 and 2, respectively, and $A$ is the area of one cell. If $Q_{a}$ is less than $Q_{c}$, one would not expect local upconing into the dune sand. If $Q_{a}$ is greater than $Q_{c}$, it is possible that local upconing could occur. However, when $Q_{a}$ is greater than $Q_{c}$, local upconing is not certain because $Q_{a}$ is distributed over the entire cell and not concentrated at the hypothetical well.

\section{Fraction of Seawater in Pumped Water}

An estimate of the maximum chloride concentration in the water pumped from each well was obtained by assuming that all water flowing upward from the fine-grained deposits was seawater. This chloride concentration, $C$, is given by,

$$
\mathrm{C}=(19,000 \mathrm{mg} / \mathrm{L}) \mathrm{Q}_{\mathrm{w}} / \mathrm{Q}_{\mathrm{a}},
$$

where $Q_{W}$ is the total pumping rate from a well and $Q_{a}$ is given by equation 4 .

\section{WATER AVAILABILITY}

\section{Maximizing Ground-Water Pumpage}

An objective of this investigation was to determine the maximum rate at which water could be pumped from the dune aquifer without inducing seawater flow into the wells at an unacceptable rate. The numerical model, together with independent calculations of local seawater upconing and chloride concentrations in pumped water, was used to evaluate various alternative pumping rates and distributions. The recharge rate used in these simulations was the long-term average, 38 inches per year. The maximum total quantity of water that could be pumped from existing and proposed production wells and satisfy the criteria listed in the following section was $17 \mathrm{Mgal} / \mathrm{d}$. This is equivalent to 45 percent of the mean annual recharge over the model area. The proposed wells were assumed to be screened in the bottom 20 feet of the dune aquifer. The distribution of pumpage for the $17 \mathrm{Mgal} / \mathrm{d}$ rate and alternative total pumping rates are presented and discussed in the "Results" section.

\section{Criteria}

The different pumping alternatives were required to meet the following criteria.

1. A zone of the dune aquifer without any seawater (a buffer zone) was maintained between the ocean and the pumped wells. 
2. The model-simulated regional freshwater-seawater interface in the vicinity of the pumped wells was not allowed to rise into the dune-sand aquifer.

3. The local cone of seawater beneath a pumped yell was not allowed to rise into the dune aquifer.

4. The calculated upper limit of the chloride concentration in pumped water from each well was kept below $250 \mathrm{mg} / \mathrm{L}$, which is the recommended maximum chloride concentration for drinking water (U.S. Environmental Protection Agency, 1977).

Criteria 2 and 4 were satisfied for each of the pumping distributions in the following section of this report, but criterion 3 could not always be satisfied. However, failure to satisfy criterion 3 was not considered serious and was permitted as long as criterion 4 was satisfied.

The risks associated with using the model to determine if seawater intrusion would occur laterally or vertically were estimated by taking into consideration the probable error in the altitude of the modelsimulated interface. For a risk of 0.1 (the probability that criteria 1 and 2 for seawater intrusion would not be met), the following increment of altitude was added to the simulated altitude of the interface:

$$
(40 \mathrm{ft} / \mathrm{ft})(3.5 \mathrm{ft})(1.28)=180 \mathrm{ft} .
$$

In this computation $40 \mathrm{ft} / \mathrm{ft}$ is the change in interface depths per change in head; $3.5 \mathrm{ft}$ is the root-mean-square error (standard deviation) in simulated head; and the factor 1.28 is the number of standard deviations beyond which the area under the normal error curve is 0.1 .

If the criteria are met when 180 feet are added to the altitude of the simulated interface, then the risk of seawater intrusion is less than 0.1. Thus, it is 90 percent certain that the thickness of freshwater is at least as thick as the value calculated by the model minus 180 feet.

\section{Results}

Simulated ground-water heads in the upper layer of the model for total pumping rates of 10,14 , and $17 \mathrm{Mgal} / \mathrm{d}$ are shown in figures 25 , 26 , and 27. Computations indicated that the earlier stated criteria could not be satisfied when the total pumpage was greater than 17 Mgal/d. The pumpage distributions used in the examples to obtain 10, 14 , and $17 \mathrm{Mgal} / \mathrm{d}$ are not unique; other distributions of pumpage that satisfy the designated criteria exist. The freedom to vary the distribution of pumpage to obtain $10 \mathrm{Mgal} / \mathrm{d}$ is large, but decreases with increasing total pumpage and is severely limited with the $17 \mathrm{Mgal} / \mathrm{d}$ alternative. For each of the three withdrawal alternatives, the maximum landward extent of simulated freshwater-seawater interface in the dune aquifer for layer 2, and the extent of interface when $180 \mathrm{ft}$ are added to the altitude of the simulated interface, are shown in figures 28,29 , and 30 . Generalized hydrogeologic sections $B-B^{\prime}$ to $F-F^{\prime}$, showing the 


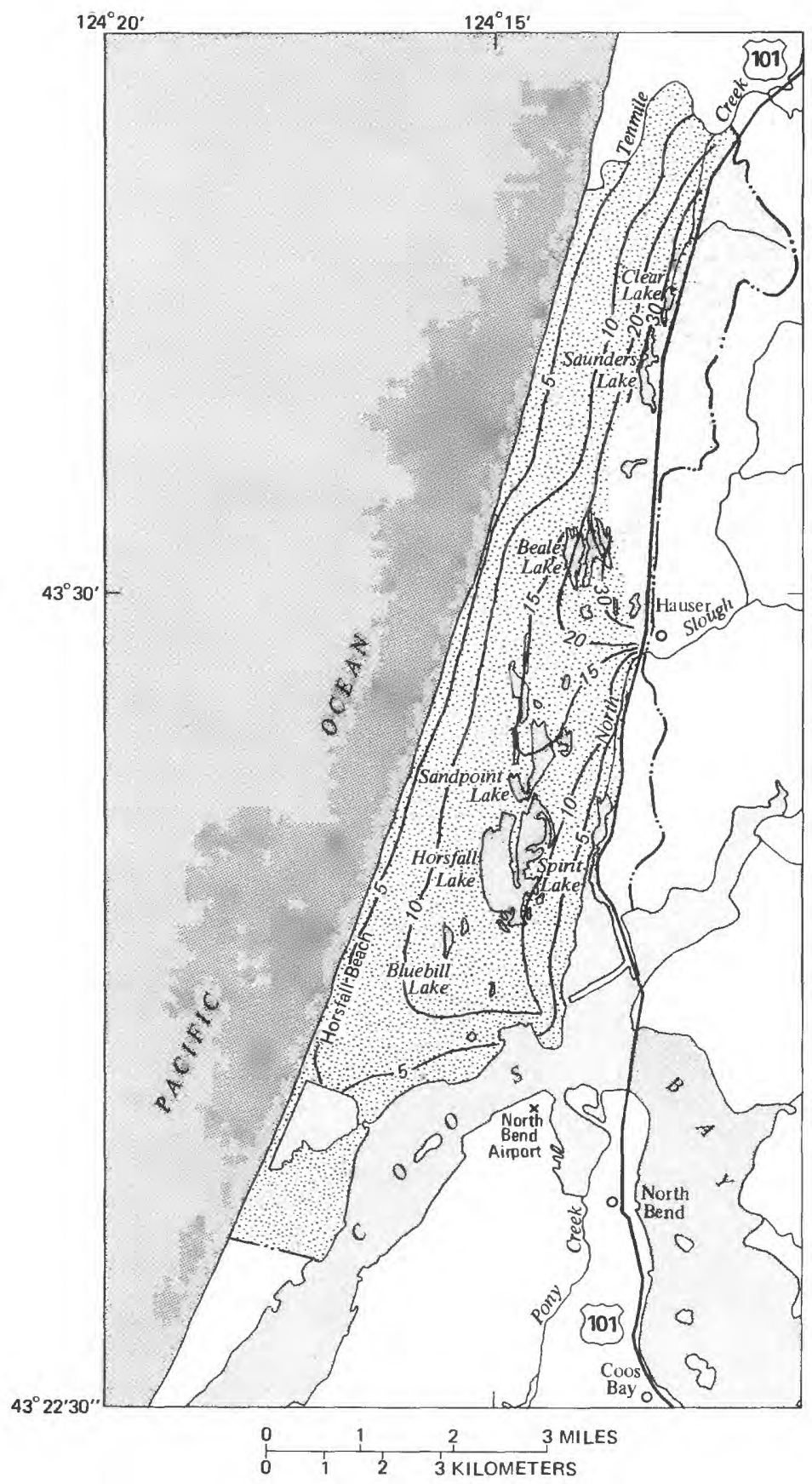

\section{EXPLANATION}

Dune-sand aquifer

Pleistocene and fine-grained Tertiary deposits

Study area boundary

-10- Water-level contour-Shows altitude of water level when pumping 10 million gallons

per day. Contour interval 5 and 10 feet. Datum is sea level.

Figure 25.--Simulated water-level contours in the dune aquifer as a result of pumping 10 million gallons per day. 


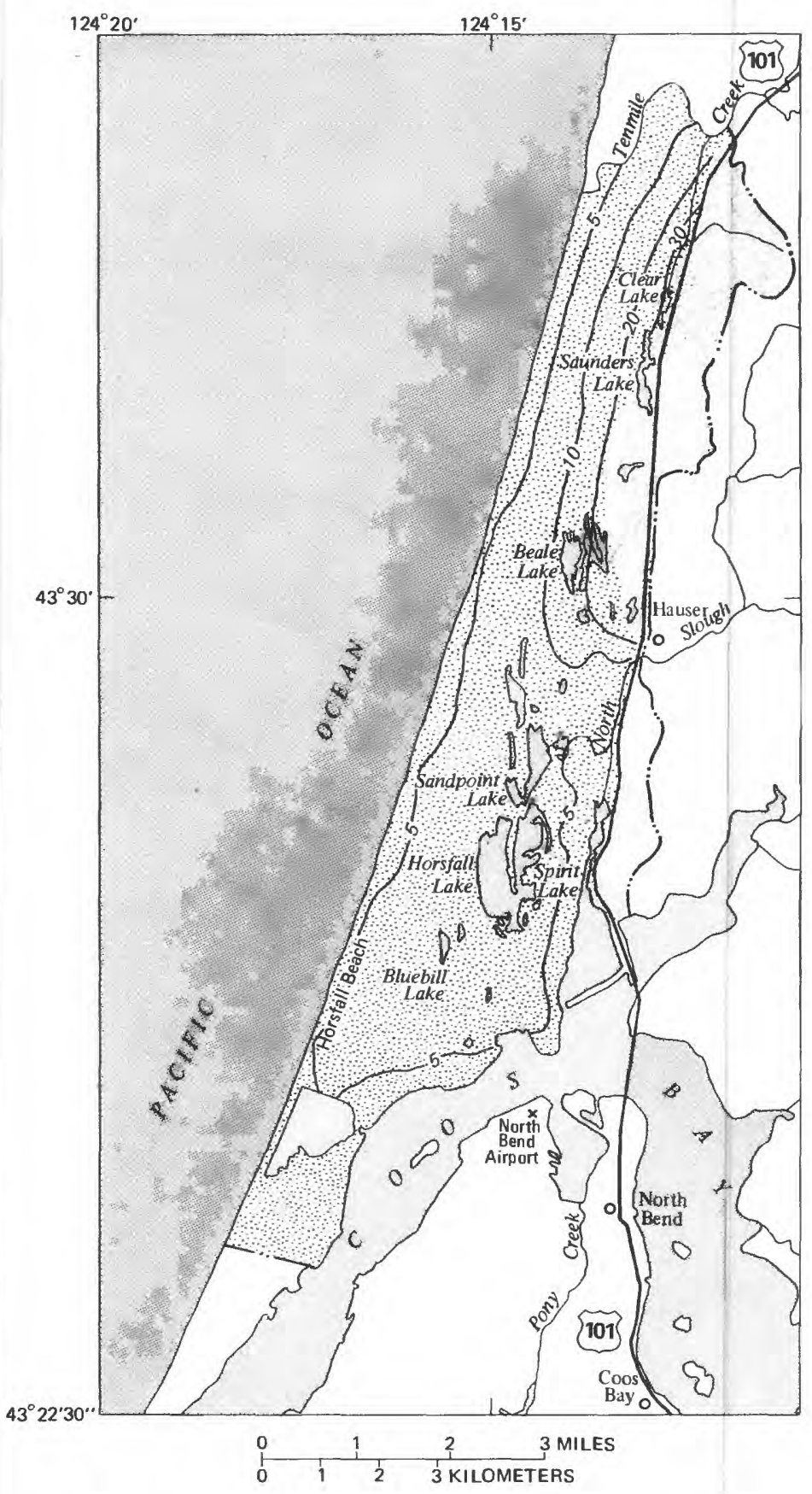

EXPLANATION

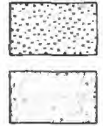

Dune-sand aquifer

Pleistocene and fine-grained Tertiary deposits

- - S - Study area boundary

-10 - Water-level contour-Shows altitude of water level when pumping 14 million gallons per day. Contour interval 5 and 10 feet. Datum is sea level.

Figure 26.--Simulated water-level contours in the dune aquifer as a result of pumping 14 million gallons per day. 


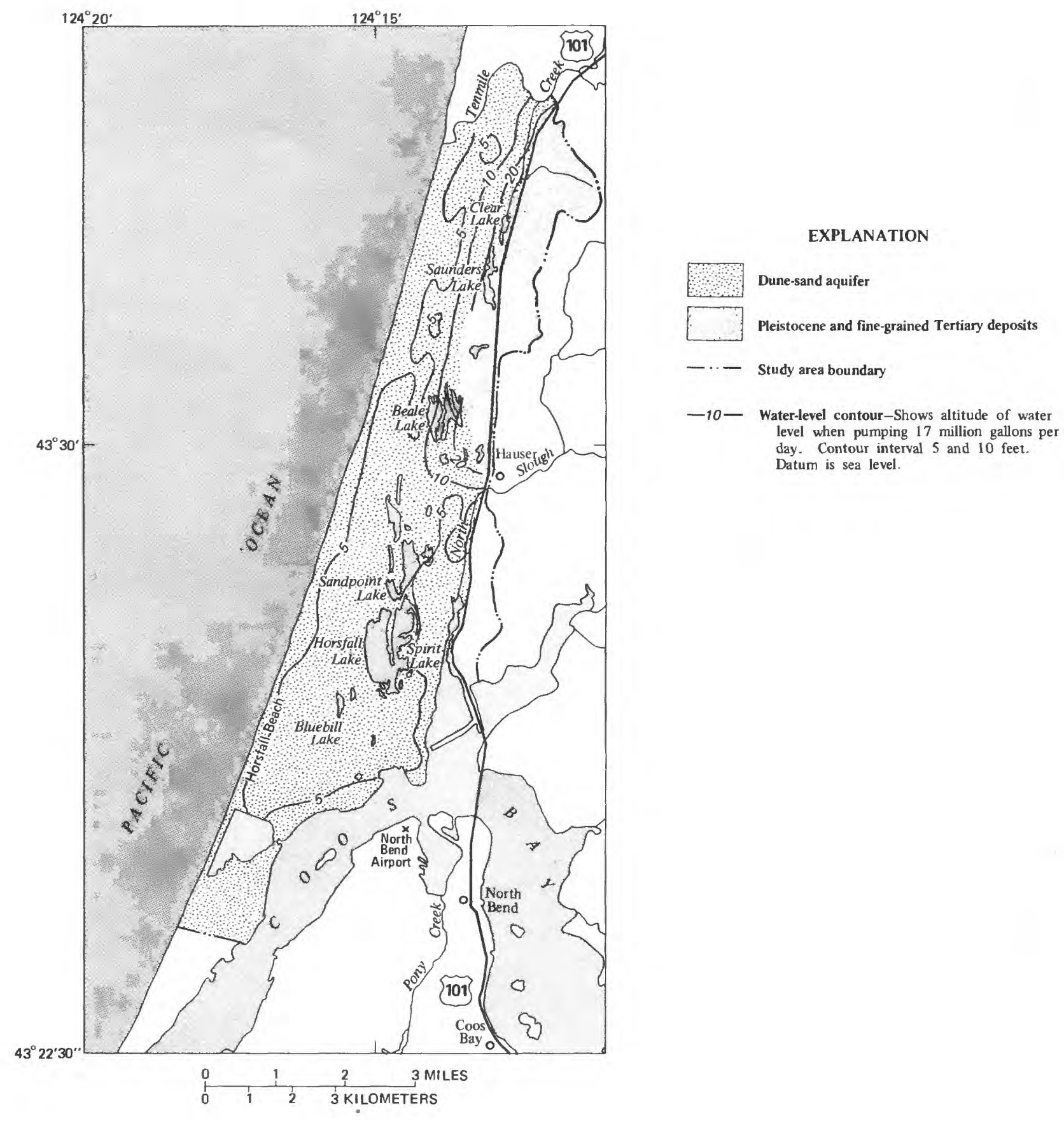

Figure 27.--Simulated water-level contours in the dune aquifer as a result of pumping 17 million gallons per day. 


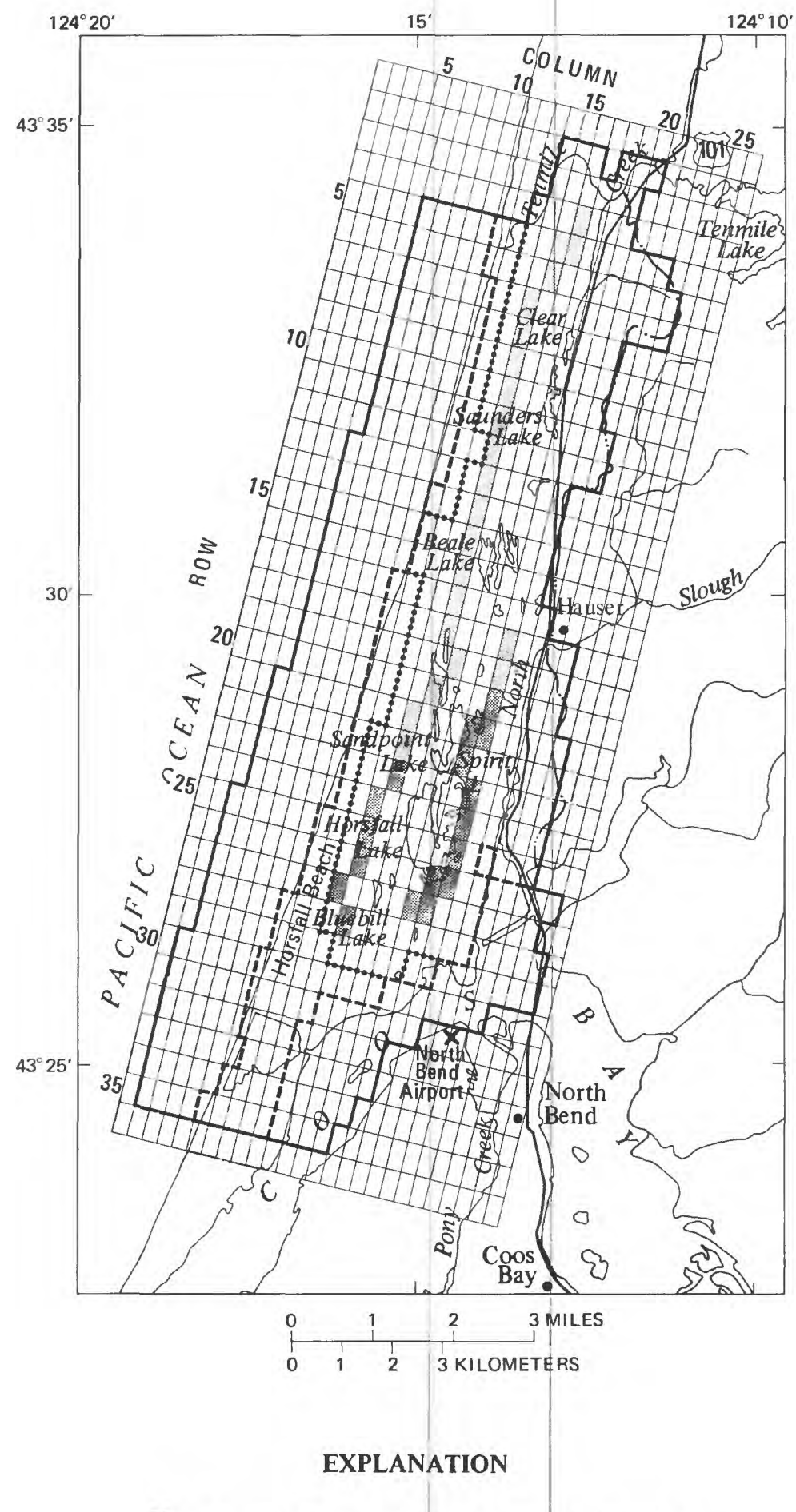

Cell with pumpage from existing production well Cell with pumpage from proposed production well

Cell with no pumpage

Boundary indicating position of simulated freshwaterseawater interface in layer 2

Boundary indicating position of simulated freshwaterseawater interface in layer 2 based on 0.1 percent error

Model boundary

Figure 28.--Maximum landward extent of the simulated freshwater-seawater interface as a result of pumping 10 million gallons per day. 


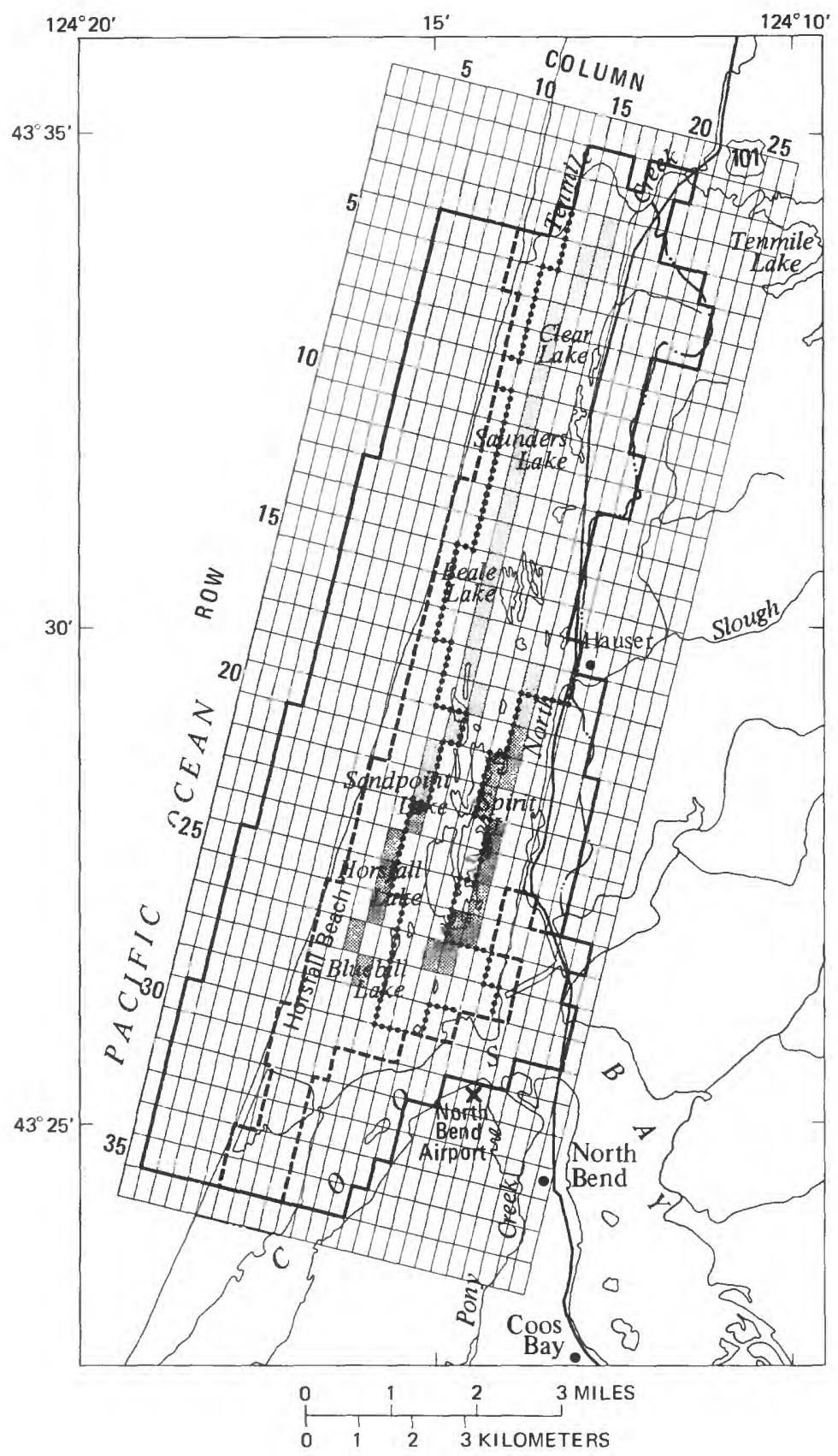

EXPLANATION

Cell with pumpage from existing production well

Cell with pumpage from proposed production well

Cell with no pumpage

Boundary indicating position of simulated freshwaterseawater interface in layer 2

......... Boundary indicating position of simulated freshwaterseawater interface in layer 2 based on 0.1 percent error

Model boundary

Figure 29.--Maximum landward extent of the simulated freshwater-seawater interface as a result of pumping 14 million gallons per day. 


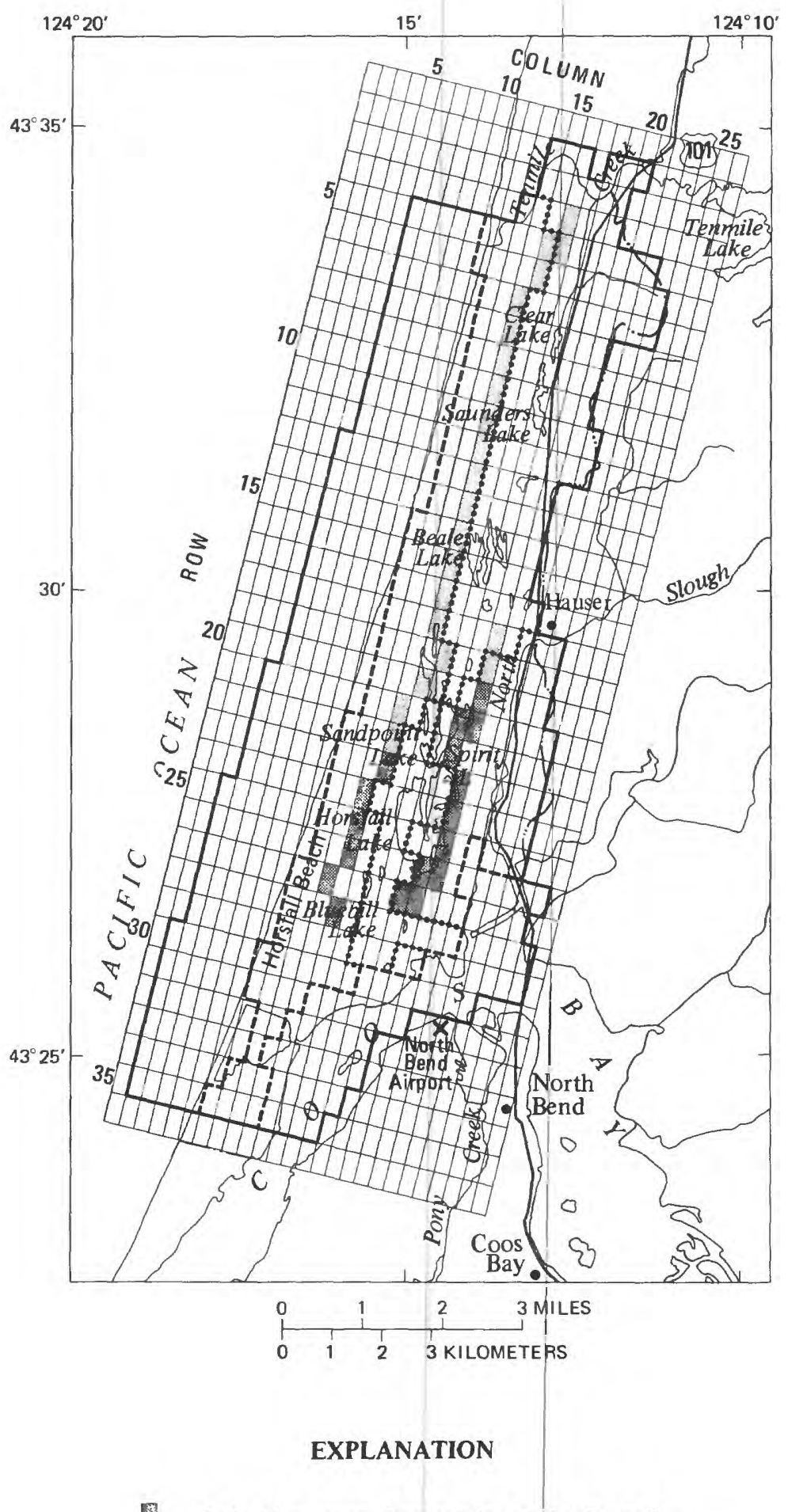

Cell with pumpage from existing production well

Cell with pumpage from proposed production well

Cell with no pumpage

Boundary indicating position of simulated freshwaterseawater interface in layer 2

......... Boundary indicating position of simulated freshwaterseawater interface in layer 2 based on 0.1 percent error

Model boundary

Figure 30.--Maximum landward extent of the simulated freshwater-seawater interface as a result of pumping 17 million gallons per day. 
regional freshwater-seawater interface for the three alternatives, are shown in figure 31. Locations of these generalized hydrogeologic sections are shown in figure 23. Well withdrawal rates, calculated chloride concentrations, and depth to the interface from bottom of the dune aquifer (layer 2) are given in tables 5 and 6 .

Table 5. - Ground-water pumping rates, calculated chloride concentrations, and simulated distance from bottom of the aquifer to the freshwater-seawater interface for 1984 and 1987 simulations

\begin{tabular}{|c|c|c|c|c|c|c|c|c|c|}
\hline \multirow{3}{*}{$\frac{\text { Yell }}{41}$} & \multicolumn{3}{|c|}{1984 model calibration } & \multicolumn{3}{|c|}{1987} & \multicolumn{3}{|c|}{1987 optimization } \\
\hline & $\begin{array}{l}\text { Pumping rate } \\
\text { (gallons per } \\
\text { minute) }\end{array}$ & $\begin{array}{l}\text { Calculated } \\
\text { chloride } \\
\text { concentration } \\
\text { (milligrams } \\
\text { per liter) }\end{array}$ & $\begin{array}{l}\text { Distance } \\
\text { to interface } \\
\text { (feet) }\end{array}$ & $\begin{array}{l}\text { Actual } \\
\text { pumping } \\
\text { rate } \\
\text { (gallons } \\
\text { per minute) }\end{array}$ & $\begin{array}{l}\text { Calculated } \\
\text { Chloride } \\
\text { concentration } \\
\text { (milligrams } \\
\text { per liter) }\end{array}$ & $\begin{array}{l}\text { Distance } \\
\text { to interface } \\
\text { (feet) }\end{array}$ & $\begin{array}{l}\text { Optimized } \\
\text { pumping } \\
\text { rate } \\
\text { (gallons } \\
\text { per minute) }\end{array}$ & $\begin{array}{l}\text { Calculated } \\
\text { chloride } \\
\text { concentration } \\
\text { (milligrams } \\
\text { per liter) }\end{array}$ & $\begin{array}{l}\text { Distance } \\
\text { to interface } \\
\text { (feet) }\end{array}$ \\
\hline & 124.8 & 5 & 584 & 143 & 14 & 389 & 320 & 25 & 305 \\
\hline 42 & 71.6 & 0 & 419 & 92 & 7 & 276 & 130 & 15 & 253 \\
\hline $4 \overline{3}$ & 180 & 15 & 339 & 190 & 18 & 201 & 110 & 12 & 218 \\
\hline 45 & 232 & 3 & 269 & 313 & 9 & 148 & 70 & 0 & 199 \\
\hline 46 & 275 & 12 & 281 & 295 & 14 & 164 & 94 & 0 & 218 \\
\hline 47 & 1.6 & 0 & 568 & 2.9 & 0 & 362 & 195 & 0 & 321 \\
\hline 48 & 1.7 & 0 & 758 & 131 & 5 & 334 & 185 & 18 & 283 \\
\hline 49 & 1.4 & 0 & 574 & 56 & 0 & 342 & 185 & 15 & 278 \\
\hline 50 & 5.8 & 0 & 499 & 49 & 0 & 287 & 110 & 0 & 232 \\
\hline 51 & 9.95 & 0 & 400 & 35.5 & 0 & 183 & 37.5 & 0 & 172 \\
\hline 52 & 9.95 & 0 & 400 & 35.5 & 0 & 183 & 37.5 & 0 & 172 \\
\hline 53 & 154.5 & 0 & 480 & 193.75 & 30 & 195 & 120 & 23 & 236 \\
\hline 54 & 154.5 & 0 & 480 & 193.75 & 30 & 195 & 120 & 23 & 236 \\
\hline 57 & 154 & 27 & 573 & 181 & 30 & 289 & 190 & 30 & 267 \\
\hline 58 & 142 & 10 & 651 & 297 & 30 & 322 & 290 & 30 & 312 \\
\hline 59 & 233 & 17 & 514 & 252 & 30 & 232 & 190 & 25 & 234 \\
\hline 60 & 243 & 22 & 714 & 246 & 36 & 430 & 320 & 44 & 370 \\
\hline
\end{tabular}

A comparison of figures 25,26 , and 27 shows an increasing decline of water levels as a result of increased pumping. The larger declines occur in the southern half of the dune aquifer. The water levels in this area drop to less than 10 feet when pumping is increased to $14 \mathrm{Mgal} / \mathrm{d}$ and are slightly less when pumping is increased to $17 \mathrm{Mgal} / \mathrm{d}$. In the vicinity of the lakes, simulated water levels decline below the bottom of the lakes, indicating that the lakes could go dry unless they are artificially maintained (table 7). In general, as pumpage increases, ground-water levels decline and the freshwater-seawater interface moves upward. If pumping increases beyond $17 \mathrm{Mgal} / \mathrm{d}$, upconing of seawater or the regional freshwater-seawater interface could rise to levels where seawater would flow into wells.

The model-predicted maximum landward extent of the seawater interface was generally within 1,000 feet of the coastline for all three pumping alternatives. But for each pumping alternative there is a 10-percent risk that the location of the interface could be located at any site as far inland as shown in figures 28,29 , and 30 . When pumping $10 \mathrm{Mgal} / \mathrm{d}$, the potential for horizontal seawater intrusion to occur in pumped wells is less than when pumping 14 and $17 \mathrm{Mgal} / \mathrm{d}$. When pumping $10 \mathrm{Mgal} / \mathrm{d}$, the simulated interface in all five generalized hydrogeologic sections except $F-F^{\prime}$ is substantially deeper than when 14 or $17 \mathrm{Mgal} / \mathrm{d}$ are pumped. In the northern part of 


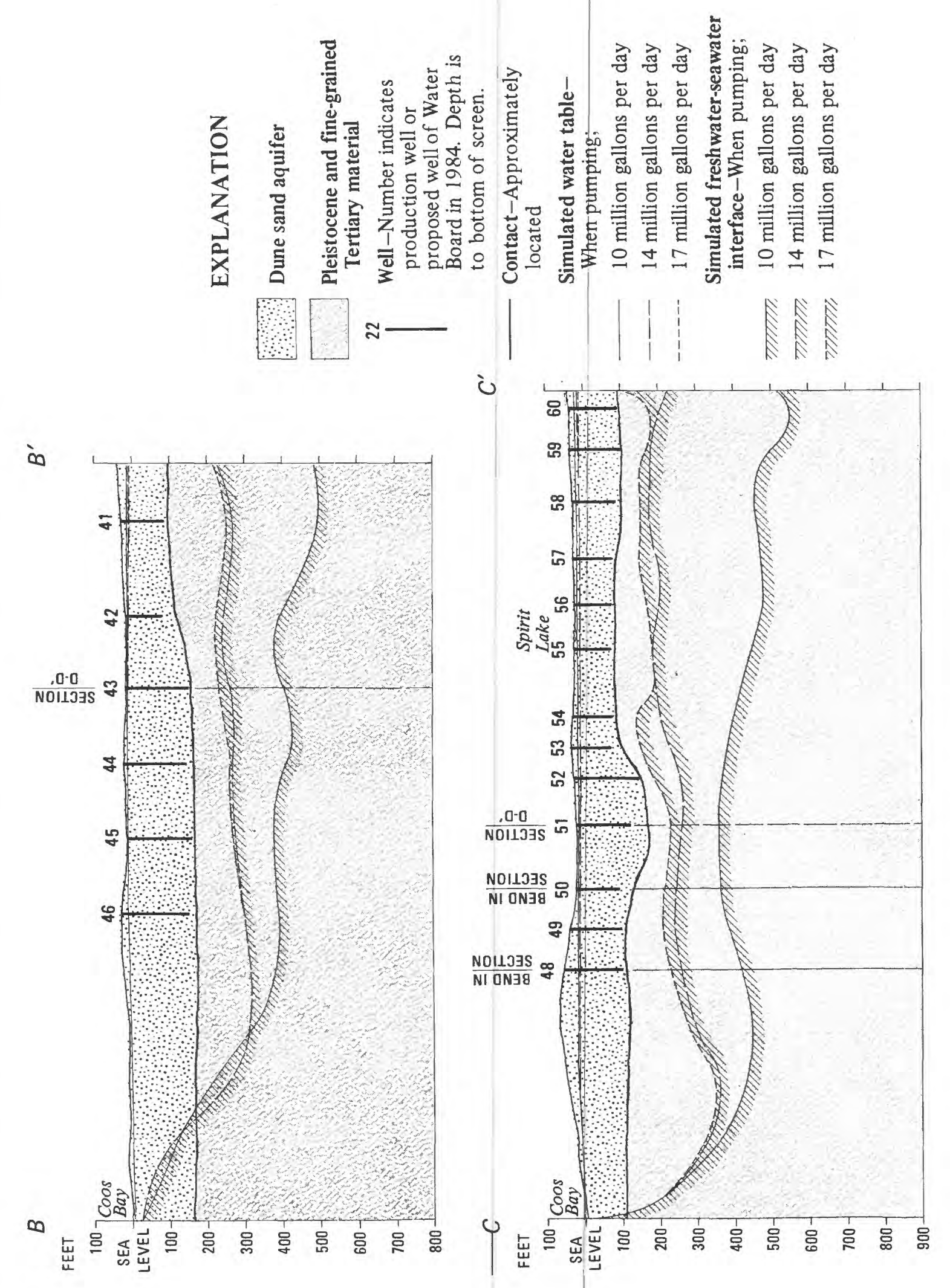


is

4

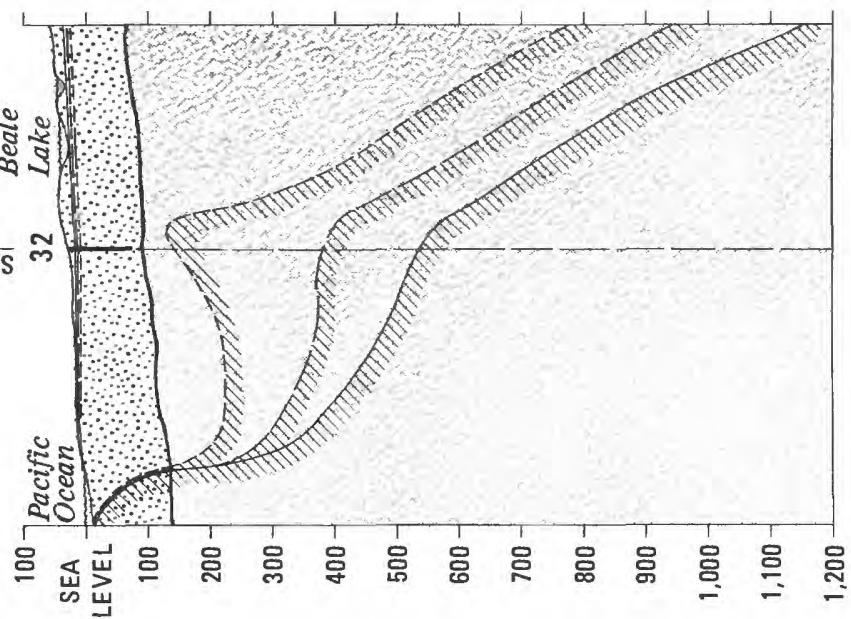

¿
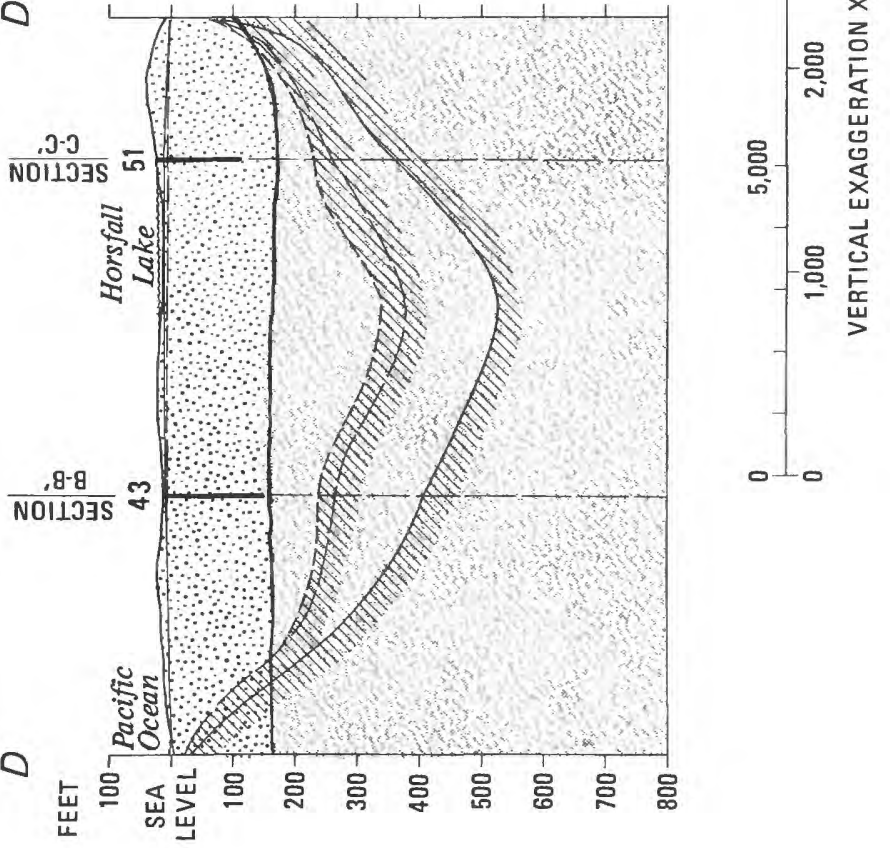

is

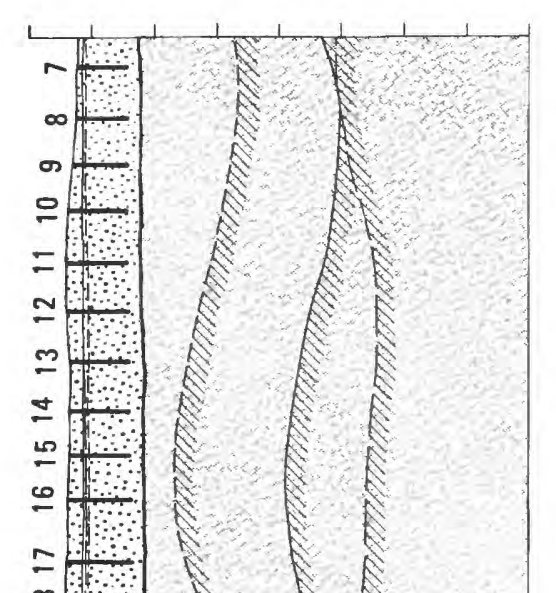

हू.

离

这

总

递总

톰

물

逜远

도를

的岁

ต่
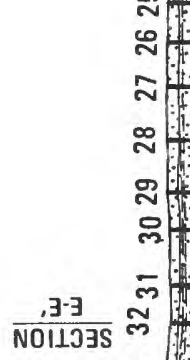

4

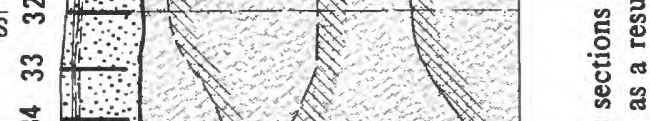

음

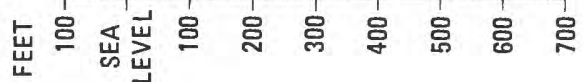


Table 6.--Ground-water pumping rates, calculated chloride concentrations, and simulated distance from bottom of the aquifer to the freshwater-seawater interface for three pumping simulations

\begin{tabular}{|c|c|c|c|c|c|c|c|c|c|c|}
\hline & $10 \mathrm{~m}$ & 1111 on gallons & per day & $14 \mathrm{mi}$ & 11ion gallons & per day & & 17 million & gallons per d & \\
\hline We 11 & $\begin{array}{l}\text { Pumping } \\
\text { rate } \\
\text { (gallons } \\
\text { per } \\
\text { minute) }\end{array}$ & $\begin{array}{l}\text { Calculated } \\
\text { chloride } \\
\text { concentra- } \\
\text { tion (milli- } \\
\text { grams per } \\
\text { liter) }\end{array}$ & $\begin{array}{l}\text { Distance } \\
\text { to interface } \\
\text { (feet) }\end{array}$ & $\begin{array}{l}\text { Pumping } \\
\text { rate } \\
\text { (gallons } \\
\text { per } \\
\text { minute) }\end{array}$ & $\begin{array}{l}\text { Calculated } \\
\text { chloride } \\
\text { concentra- } \\
\text { tion (milli- } \\
\text { grams per } \\
\text { liter) }\end{array}$ & $\begin{array}{l}\text { Distance } \\
\text { to interface } \\
\text { (feet) }\end{array}$ & $\begin{array}{l}\text { Pumping } \\
\text { rate } \\
\text { (gallons } \\
\text { per } \\
\text { minute) }\end{array}$ & $\begin{array}{l}\text { Calculated } \\
\text { chloride } \\
\text { concentra- } \\
\text { tion (milli- } \\
\text { grams per } \\
\text { liter) }\end{array}$ & $\begin{array}{l}\text { Distance } \\
\text { to interface } \\
\text { (feet) }\end{array}$ & $\begin{array}{l}\text { Altitude } \\
\text { of bottom } \\
\text { of aquifer } \\
\text { (feet below } \\
\text { sea level) }\end{array}$ \\
\hline 1 & 108 & 82 & 455 & 146.5 & 88 & 414 & 146.5 & 89 & 342 & 40 \\
\hline 2 & 108 & 126 & 536 & 146.5 & 121 & 525 & 146.5 & 121 & 328 & 40 \\
\hline 3 & 108.5 & 72 & 300 & 73.5 & 60 & 340 & 146 & 70 & $\star 130$ & 55 \\
\hline 4 & 108.5 & 72 & 300 & 73.5 & 60 & 340 & 146 & 70 & $\star 130$ & 55 \\
\hline 5 & 108.6 & 82 & 371 & 73 & 85 & 443 & 147.6 & 80 & $\star 149$ & 55 \\
\hline 6 & 108.6 & 82 & 371 & 73 & 85 & 443 & 147.6 & 80 & *149 & 55 \\
\hline 7 & 108.6 & 82 & 371 & 73 & 85 & 443 & 147.6 & 80 & *149 & 55 \\
\hline 8 & 108.5 & 50 & 333 & 146 & 53 & 339 & 153.5 & 51 & $\star 181$ & 70 \\
\hline 9 & 108.5 & 50 & 333 & 146 & 53 & 339 & 153.5 & 51 & $\star 181$ & 70 \\
\hline 10 & 108.6 & 54 & 306 & 73 & 59 & 395 & 146 & 53 & $\star 95$ & 65 \\
\hline 11 & 108.6 & 54 & 306 & 73 & 59 & 395 & 146 & 53 & $\star 95$ & 65 \\
\hline 12 & 108.6 & 54 & 306 & 73 & 59 & 395 & 146 & 53 & $\star 95$ & 65 \\
\hline 13 & 108.6 & 61 & $\star 275$ & 73 & 62 & 401 & 146 & 50 & $\star 97$ & 50 \\
\hline 14 & 108.6 & 61 & $\star 275$ & 73 & 62 & 401 & 146 & 50 & $\star 97$ & 50 \\
\hline 15 & 108.6 & 61 & $\star 275$ & 73 & 62 & 401 & 146 & 50 & $\star 97$ & 50 \\
\hline 16 & 108.6 & 61 & $\star 242$ & 71 & 61 & 373 & 145 & 50 & $\star 74$ & 70 \\
\hline 17 & 108.6 & 61 & $\star 242$ & 71 & 61 & 373 & 145 & 50 & $\star 74$ & 70 \\
\hline 18 & 108,6 & 61 & $\star 242$ & 71 & 61 & 373 & 145 & 50 & $\star 74$ & 70 \\
\hline 18 & 108.5 & 63 & 267 & 100 & 65 & 361 & 148.5 & 60 & $\star 138$ & 70 \\
\hline 20 & 108.5 & 63 & 267 & 100 & 65 & 361 & 148.5 & 60 & *138 & 70 \\
\hline 21 & 108,6 & 59 & $\star 195$ & 67 & 61 & 321 & 97 & 56 & *122 & 75 \\
\hline 22 & 108.6 & 59 & *195 & 67 & 61 & 321 & 97 & 56 & *122 & 75 \\
\hline 23 & 108.6 & 59 & *195 & 67 & 61 & 321 & 97 & 56 & $\star 122$ & 75 \\
\hline 24 & 108.6 & 61 & $\star 233$ & 67 & 61 & 324 & 97 & 58 & $\star 122$ & 80 \\
\hline 25 & 108.6 & 61 & $\star 233$ & 67 & 61 & 324 & 97 & 58 & $\star 122$ & 80 \\
\hline 26 & 108.6 & 61 & $\star 233$ & 67 & 61 & 324 & 97 & 58 & $\star 122$ & 80 \\
\hline 27 & 108.5 & 50 & 346 & 100 & 48 & 324 & 208.5 & 44 & $\star 78$ & 80 \\
\hline 28 & 108.5 & 50 & 346 & 100 & 48 & 324 & 208.5 & 44 & $\star 78$ & 80 \\
\hline 29 & 108.5 & 44 & 427 & 189 & 45 & 277 & 210.5 & 39 & $\star 75$ & 85 \\
\hline 30 & 108.5 & 44 & 427 & 189 & 45 & 277 & 210.5 & 39 & $\star 75$ & 85 \\
\hline 31 & 108.6 & 40 & 466 & 98 & 40 & 306 & 208 & 38 & *51 & 85 \\
\hline 32 & 108.6 & 40 & 466 & 98 & 40 & 306 & 208 & 38 & $\star 51$ & 85 \\
\hline 33 & 108.6 & 40 & 466 & 98 & 40 & 306 & 208 & 38 & $* 51$ & 85 \\
\hline 34 & 108 & 19 & 526 & 380.5 & 40 & 237 & 293 & 34 & 146 & 90 \\
\hline 35 & 108.5 & 28 & 480 & 190 & 32 & 181 & 216 & 33 & * 104 & 90 \\
\hline
\end{tabular}


Table 6.--Ground-water pumping rates, calculated chloride concentrations, and simulated distance from bottom of the aquifer to the freshwater-seawater interface for three pumping simulations--Continued

\begin{tabular}{|c|c|c|c|c|c|c|c|c|c|c|}
\hline & $10 \mathrm{~m}$ & illion gallons & per day & $14 \mathrm{mi}$ & llion gallons & per day & & 17 million & gallons per d & \\
\hline We11 & $\begin{array}{l}\text { Pumping } \\
\text { rate } \\
\text { (gallons } \\
\text { per } \\
\text { minute) } \\
\end{array}$ & $\begin{array}{l}\text { Calculated } \\
\text { chloride } \\
\text { concentra- } \\
\text { tion (milli- } \\
\text { grams per } \\
\text { liter) }\end{array}$ & $\begin{array}{l}\text { Distance } \\
\text { to interface } \\
\text { (feet) }\end{array}$ & $\begin{array}{l}\text { Pumping } \\
\text { rate } \\
\text { (gallons } \\
\text { per } \\
\text { minute) } \\
\end{array}$ & $\begin{array}{l}\text { Calculated } \\
\text { chloride } \\
\text { concentra- } \\
\text { tion (milli- } \\
\text { grams per } \\
\text { liter) }\end{array}$ & $\begin{array}{l}\text { Distance } \\
\text { to interface } \\
\text { (feet) }\end{array}$ & $\begin{array}{l}\text { Pumping } \\
\text { rate } \\
\text { (gallons } \\
\text { per } \\
\text { minute) } \\
\end{array}$ & $\begin{array}{l}\text { Calculated } \\
\text { chloride } \\
\text { concentra- } \\
\text { tion (mill- } \\
\text { grams per } \\
\text { liter) }\end{array}$ & $\begin{array}{l}\text { Distance } \\
\text { to interface } \\
\text { (feet) }\end{array}$ & $\begin{array}{l}\text { Altitude } \\
\text { of bottom } \\
\text { of aquifer } \\
\text { (feet below } \\
\text { sea level) }\end{array}$ \\
\hline 36 & 108.5 & 28 & 480 & 190 & 32 & 181 & 216 & 33 & $* 104$ & 90 \\
\hline 37 & 108 & 6 & 541 & 370.5 & 33 & *162 & 322 & 32 & 128 & 90 \\
\hline 38 & 108 & 13 & 468 & 316 & 27 & 144 & 296 & 28 & 127 & 90 \\
\hline 39 & 108 & 6 & 382 & 277.5 & 25 & 125 & 284 & 26 & 109 & 95 \\
\hline 40 & 108 & 6 & 399 & 307.5 & 27 & 140 & 288 & 26 & 130 & 90 \\
\hline 41 & 108 & 6 & 405 & 241 & 23 & 186 & 238 & 23 & 170 & 84 \\
\hline 42 & 216 . & 6 & 292 & 256 & 21 & 132 & 284 & 22 & 111 & 112 \\
\hline 43 & 108 & 13 & 244 & 224.5 & 18 & 99 & 292 & 19 & 78 & 157 \\
\hline 44 & 108 & 0 & 246 & 362.5 & 13 & 96 & 306 & 19 & 94 & 169 \\
\hline 45 & 108 & 0 & 214 & 243 & 11 & 100 & 210 & 13 & 108 & 162 \\
\hline 46 & 108 & 0 & 226 & 224 & 12 & 130 & 210 & 6 & 135 & 167 \\
\hline 47 & 74.5 & 0 & 352 & 229 & 18 & 190 & 243 & 10 & 171 & 114 \\
\hline 48 & 109 & 0 & 328 & 232 & 15 & 175 & 227 & 21 & 149 & 112 \\
\hline 49 & 109 & 0 & 324 & 233 & 21 & 159 & 210 & 20 & 135 & 113 \\
\hline 50 & 108 & 0 & 261 & 162 & 17 & 131 & 203 & 20 & 98 & 115 \\
\hline 51 & 86.5 & 78 & 175 & 75.5 & 9 & 76 & 91.5 & 11 & 34 & 189 \\
\hline 52. & 86.5 & 78 & 175 & 75.5 & 9 & 76 & 91.5 & 11 & 34 & 189 \\
\hline 53 & 108 & 16 & 286 & 110 & 22 & 147 & 192.5 & 28 & $*^{*} 64$ & 97 \\
\hline 54 & 108 & 16 & 286 & 110 & 22 & 147 & 192.5 & 28 & *64 & 97 \\
\hline 55 & 108 & 0 & 345 & 283 & 27 & $\star 118$ & 210 & 23 & 107 & 83 \\
\hline 56 & 108.5 & 22 & 345 & 161 & 30 & *123 & 199 & 27 & $\star 80$ & 86 \\
\hline 57 & 108.5 & 22 & 401 & 161 & 30 & $\star 123$ & 199 & 27 & $\star 80$ & 86 \\
\hline 58 & 107 & 6 & 438 & 254 & 13 & 120 & 196 & 24 & 96 & 93 \\
\hline 59 & 108 & 6 & 358 & 262 & 26 & $* 74$ & 187 & 22 & 52 & 106 \\
\hline 60 & 108 & 0 & 454 & 241.5 & 4 & *111 & 210 & 36 & 93 & 96 \\
\hline 61 & 108.5 & 41 & 460 & 112.5 & 6 & *167 & 157.5 & 51 & $\star 60$ & 65 \\
\hline 62 & 108.5 & 41 & 460 & 112.5 & 6 & $\star 167$ & 157.5 & 51 & $\star 60$ & 65 \\
\hline 63 & 108.5 & 68 & 579 & 150 & 12 & $\star 259$ & 163 & 92 & *159 & 60 \\
\hline 64 & 108.5 & 68 & 579 & 150 & 12 & $\star 259$ & 163 & 92 & *159 & 60 \\
\hline
\end{tabular}

- Where local upconing reaches bottom of dune-sand aquifer. 
Table 7.--Lake-bottom altitudes and average simulated ground-water levels, in feet above sea level

\begin{tabular}{|c|c|c|c|c|c|}
\hline \multirow[b]{2}{*}{ Lake } & \multirow[b]{2}{*}{$\begin{array}{c}\text { Lake } \\
\text { bottom }\end{array}$} & \multicolumn{4}{|c|}{ Ground-water leve1 } \\
\hline & & 1984 & 10 & $\mathrm{Mgal} / \mathrm{d}$ & $17 \mathrm{Mga} 1 / \mathrm{d}$ \\
\hline Clear & 16 & 52 & & 32 & 26 \\
\hline Saunders & 20 & 53 & & 32 & 27 \\
\hline Butterfield & 14 & 50 & & 31 & 25 \\
\hline Beale & 27 & 37 & & 18 & 9 \\
\hline Snag & 13 & 25 & & 15 & 6 \\
\hline Sandpoint & 11 & 20 & & 14 & 7 \\
\hline Horsfall & 14 & 19 & & 14 & 9 \\
\hline Spirit & 15 & 18 & & 14 & 8 \\
\hline Bluebil1 & 11 & 15 & & 11 & 8 \\
\hline
\end{tabular}

section $F-F^{\prime}$, the interface is higher when $10 \mathrm{Mgal} / \mathrm{d}$ are pumped because a larger quantity of water is pumped from the northern wells ( 7 to 26) than when $14 \mathrm{Mgal} / \mathrm{d}$ are pumped (table 6). The distance to the regional freshwaterseawater interface is within 180 feet (risk $=0.1$ ) of the bottom of the dune aquifer for 2 of the 64 production wells when 10 Mgal/d are pumped, for 24 wells when $14 \mathrm{Mgal} / \mathrm{d}$ are pumped, and for 60 wells when $17 \mathrm{Mgal} / \mathrm{d}$ are pumped. Thus, the risk of causing the regional interface to rise up into the dune-sand aquifer is probably small when a total of $10 \mathrm{Mgal} / \mathrm{d}$ are pumped, but may be larger when $17 \mathrm{Mgal} / \mathrm{d}$ are pumped.

Local seawater upconing was induced into the dune aquifer beneath 12 of the 64 production wells when $10 \mathrm{Mgal} / \mathrm{d}$ were pumped, 10 wells when $14 \mathrm{Mgal} / \mathrm{d}$ were pumped, and 41 wells when $17 \mathrm{Mgal} / \mathrm{d}$ were pumped. However, chloride concentrations were calculated to be less than $126 \mathrm{mg} / \mathrm{L}$ for all wells. Local upconing occurred at more wells when pumping rates were $10 \mathrm{Mgal} / \mathrm{d}$ than when 14 Mgal/d were pumped because of the higher rates of pumping in the northern wells (7-26), as mentioned earlier in the discussion of section $\mathrm{F}-\mathrm{F}^{\prime}$.

The model does not calculate the length of time it takes for the interface to move to a new steady-state position after pumping rates are changed. This time would depend on hydraulic conductivities of the deposits and on specific storage. If the seawater were to flow only through the fine-grained Tertiary deposits, calculated estimates of the vertical velocity indicate that it would take hundreds of years for the interface to move upward to the equilibrium position predicted by the model and shown in figure 31. This calculation is based on the model-computed head in the fine-grained Tertiary deposit beneath the pumped well and a water level in the pumped well that was estimated from the specific capacity and the pumping rate of the well. If the seawater were to flow through only dune-sand deposits, however, it is estimated that the length of time could be only a few years or less. The latter estimates should be considered speculative because they are not based on observed movements of the interface. 


\section{Optimization of 1987 Pumpage}

The distribution among the wells of total present-day pumpage ( 4.63 $\mathrm{Mgal} / \mathrm{d}$ ) was varied in simulations to reduce the probability of seawater encroachment into the dune aquifer. Pumpage was redistributed (optimized) to lower the interface where its altitudes were highest, and generally to make the depth to the interface below the bottom of the dune aquifer more nearly uniform over the area. Simulated interface positions were found to be virtually identical, but there were slight differences in the potential position of the interface based on a 0.1 percent model error (figs. 32 and 33). The simulated interface positions for both the actual and optimized pumping distributions are generally within 500 feet of the coastline except along the southeast coast, where the interface is about 1,000 feet inland (figs. 32 and 33). The simulated positions of the interface beneath the pumped wells for actual and optimized pumping distributions are shown in figure 34. Along most of section B-B', which runs in a north-south direction through the west line of wells, the simulated interface for the optimized pumpage is lower than for the actual pumpage. The reason for this is that the optimized pumpage was less than the actual pumpage for four of the six wells (43 to 46 ) and the total optimized pumpage (1.24 Mgal/d) for wells along this line is $0.54 \mathrm{Mgal} / \mathrm{d}$ less than the actual pumpage ( $1.78 \mathrm{Mgal} / \mathrm{d}$ ). Along section C-C', which runs north-south through the east line of wells, the simulated interface for the optimized pumpage is slightly higher than for the actual pumpage except near well 53, where an interface high was eliminated. The total optimized pumpage ( $3.39 \mathrm{Mgal} / \mathrm{d}$ ) along this line is $0.54 \mathrm{Mgal} / \mathrm{d}$ more than

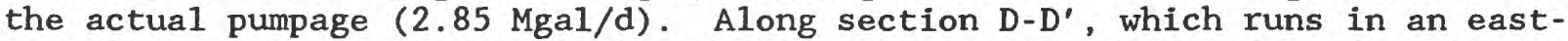
west line perpendicular to $B-B^{\prime}$ and $C-C^{\prime}$, the simulated interface for the optimized pumpage is lower than for the actual pumpage in the western part of the section and is higher in the eastern part, which is consistent with the transfer of pumpage from the west to the east line of wells.

The actual and optimized 1987 pumping rates for each well are shown in figure 35 and table 5. The distance to the simulated interface from the dune aquifer beneath each well is shown in table 5 .

Simulated water-table altitudes with the long-term mean annual recharge and actual 1987 pumpage are shown in figure 36. Simulated water-table altitudes for the optimized distribution of pumping differed from those simulated for the actual pumping by less than 2.5 feet. These simulated water-table altitudes are substantially lower than those simulated for 1984 (fig. 21) because the 1987 pumpage was greater (4.6 Mgal/d compared with 3.7 $\mathrm{Mgal} / \mathrm{d}$ ), and the long-term average recharge rate was less than for 1984 (38 in./yr compared to $47 \mathrm{in./yr).}$

\section{POSSIBLE IMPROVEMENTS TO THE MODEL}

The accuracy and reliability of most numerical ground-water models can be improved with more and improved geologic, hydrologic, and pumpage data. The most useful data for improving the model used in this study, in order of importance, would be:

1. Field data on the position of the freshwater-seawater interface along the coastline and in the vicinity of the production wells; 


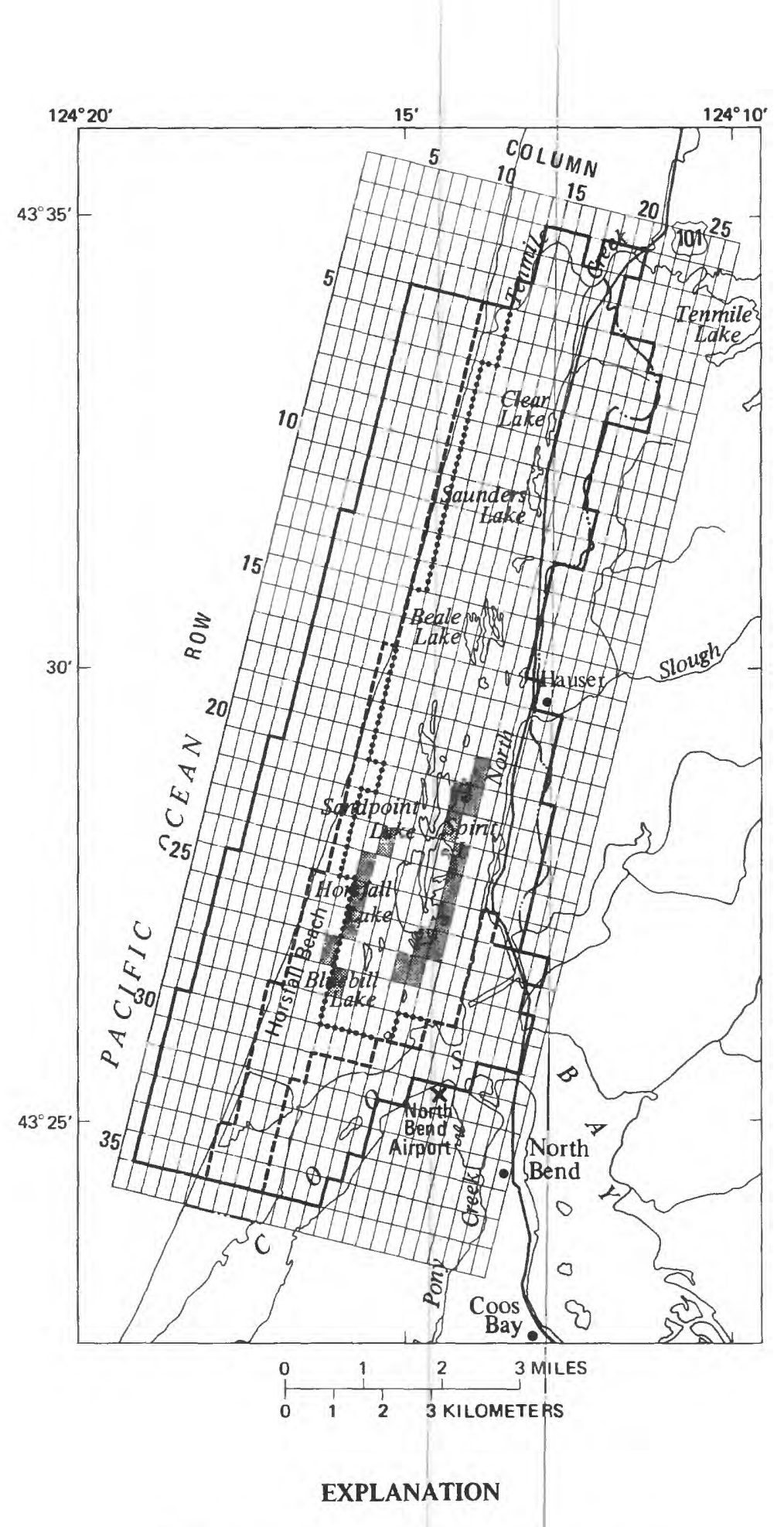




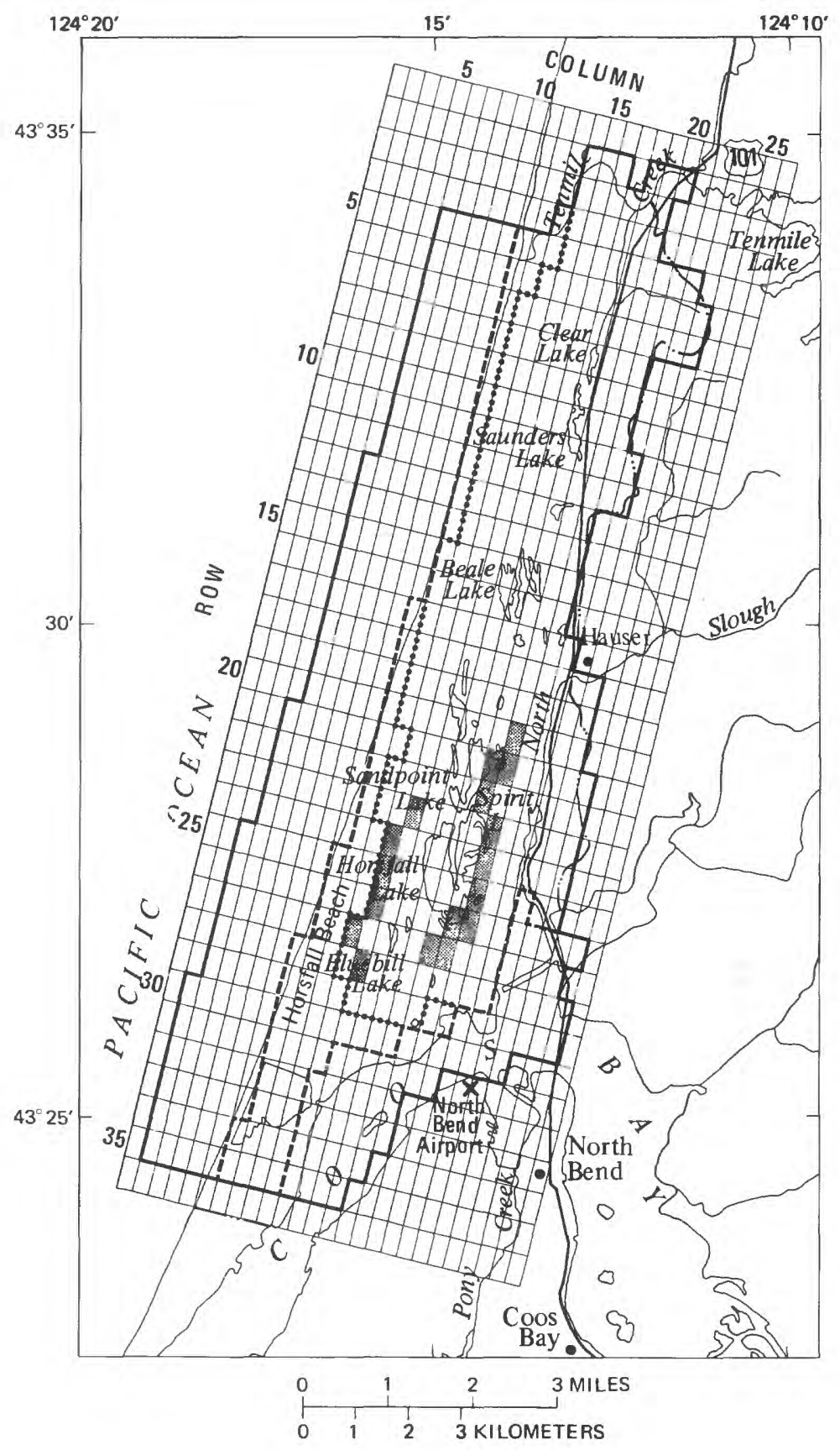

\section{EXPLANATION}

Cell with pumpage from existing production well

Cell with no pumpage

Boundary indicating position of simulated freshwaterseawater interface in layer 2

........ Boundary indicating position of simulated freshwaterseawater interface in layer 2 based on 0.1 percent error

Model boundary

Figure 33.--Maximum landward extent of the simulated freshwater-seawater interface for the optimized 1987 pumpage distribution. 


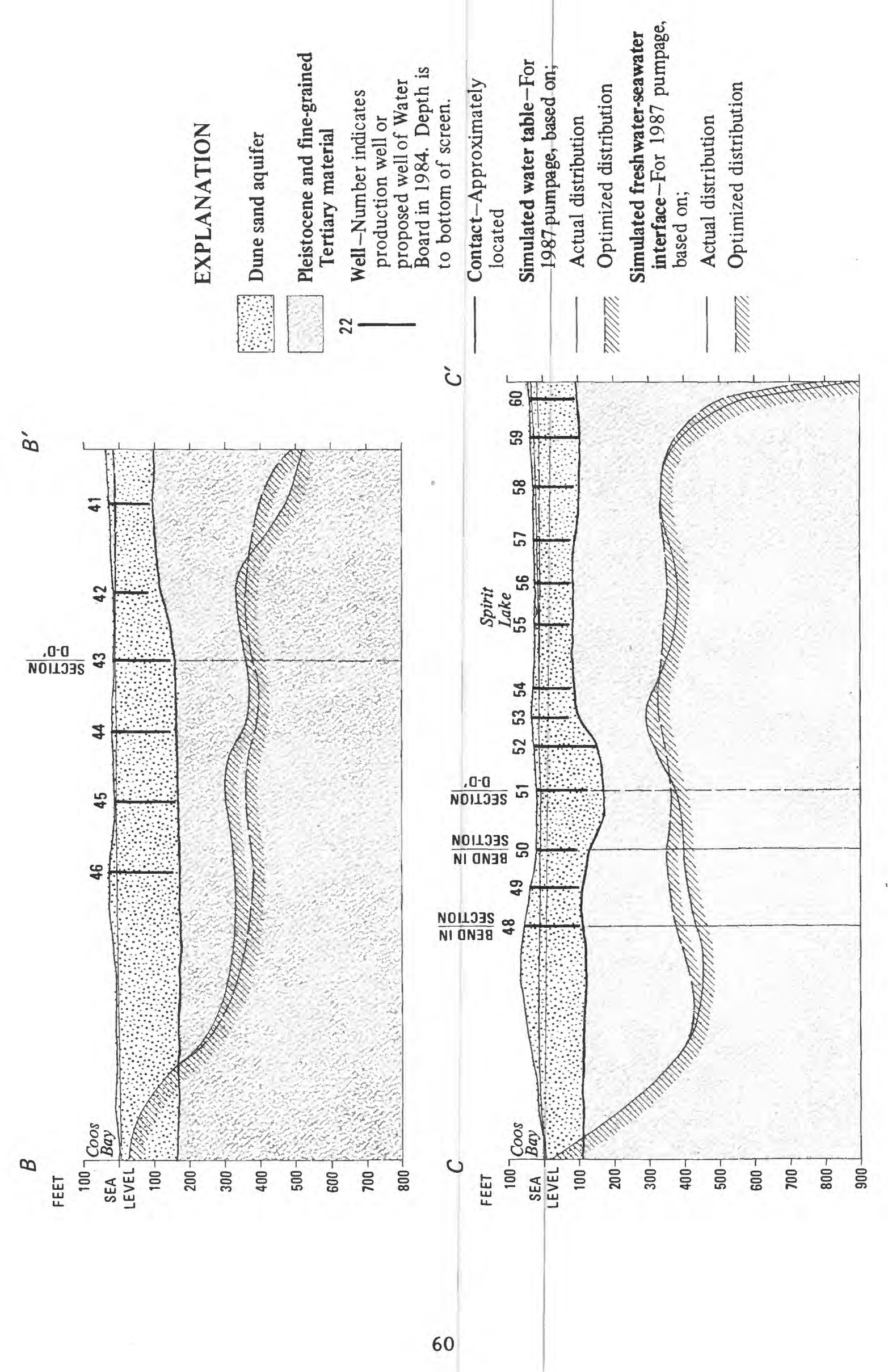




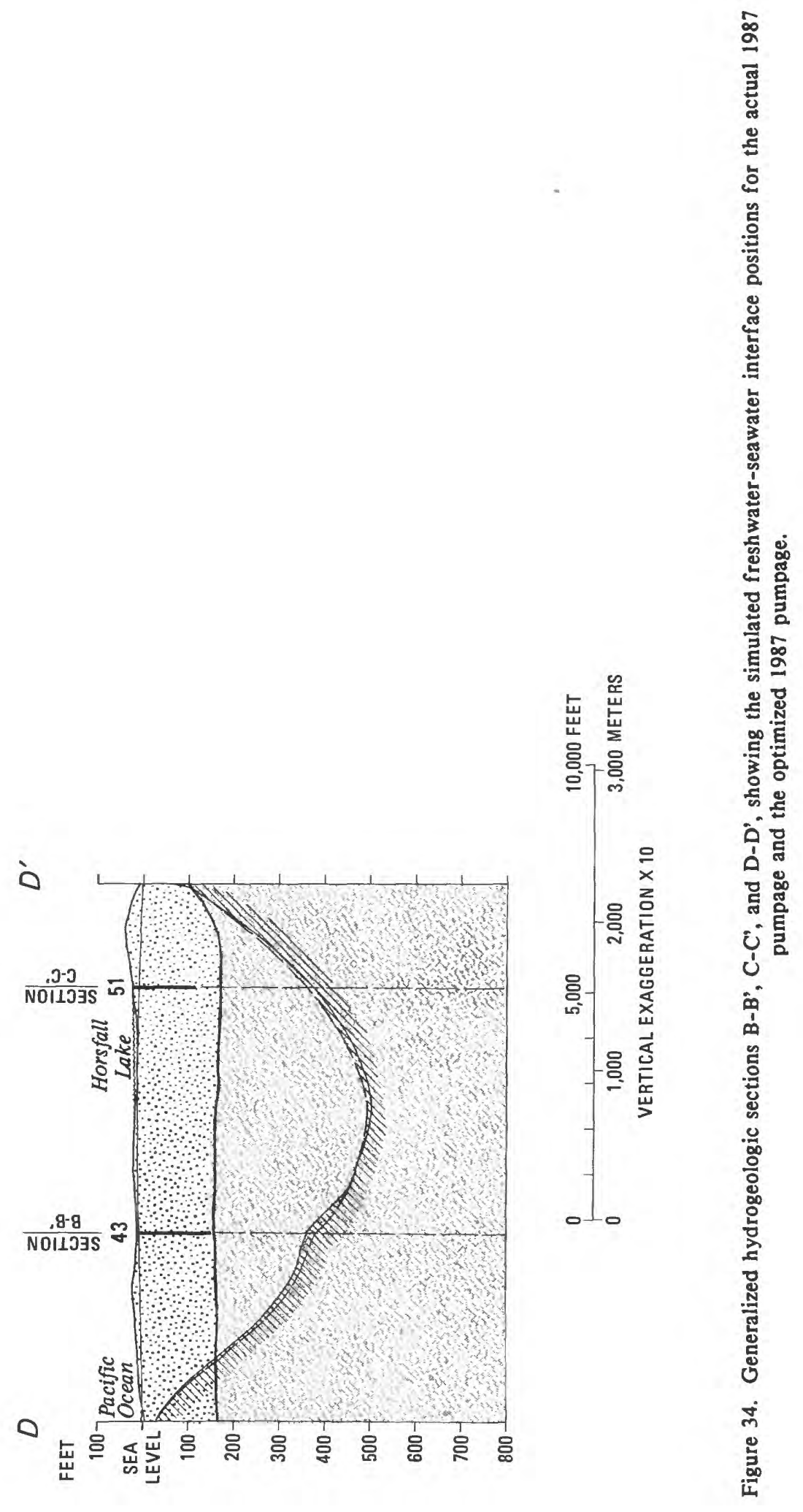




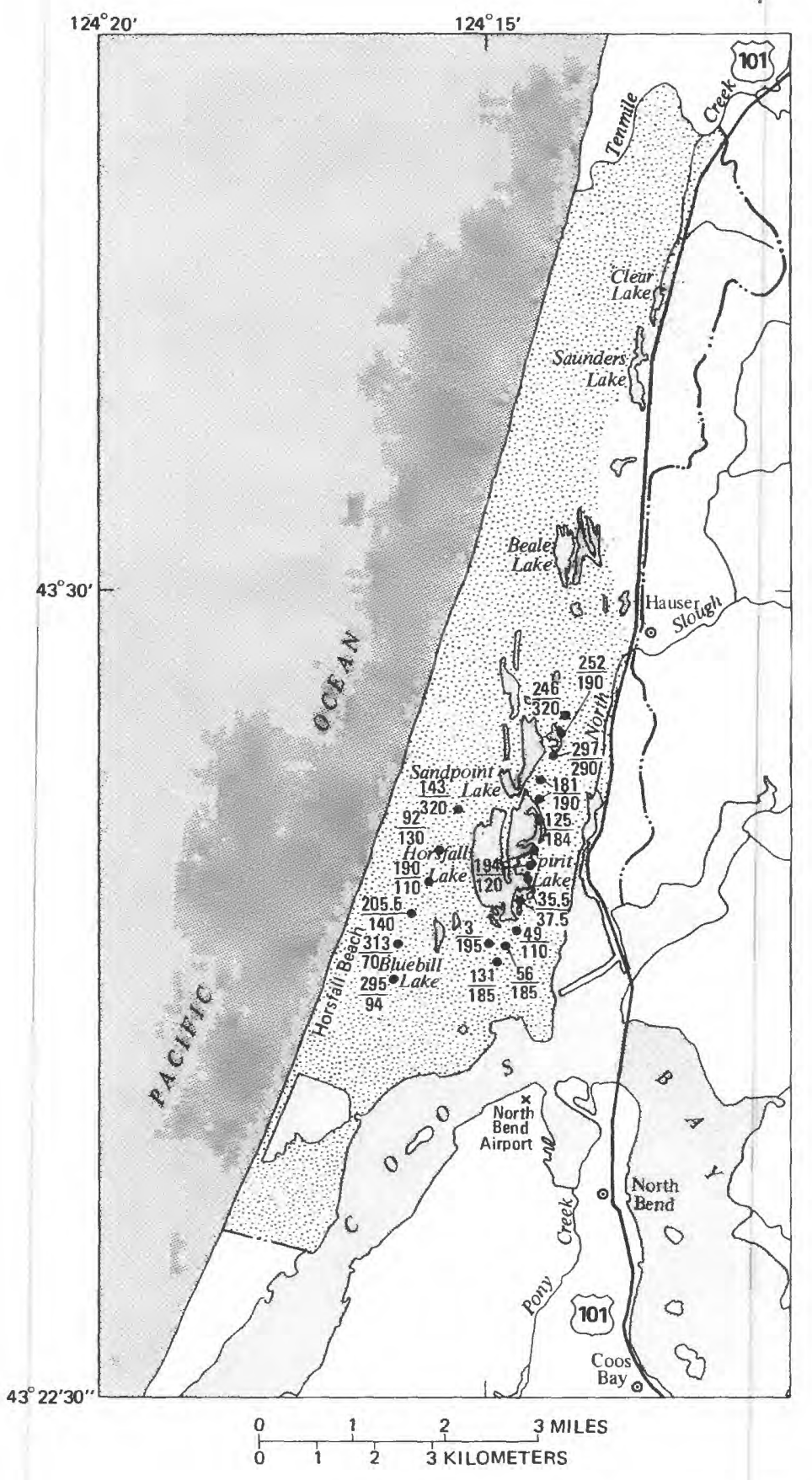

\section{EXPLANATION}

Dune-sand aquifer

Pleistocene and fine-grained Tertiary deposits

\section{- -. Study area boundary}

- Production well-Upper number is actual

$\frac{143^{\circ}}{320} 1987$ pumping rate, in gallons per minute.

Lower number is optimized pumping rate,

in gallons per minute. See table 5 .

Figure 35.--Actual and optimized distribution of 1987 pumpage. 


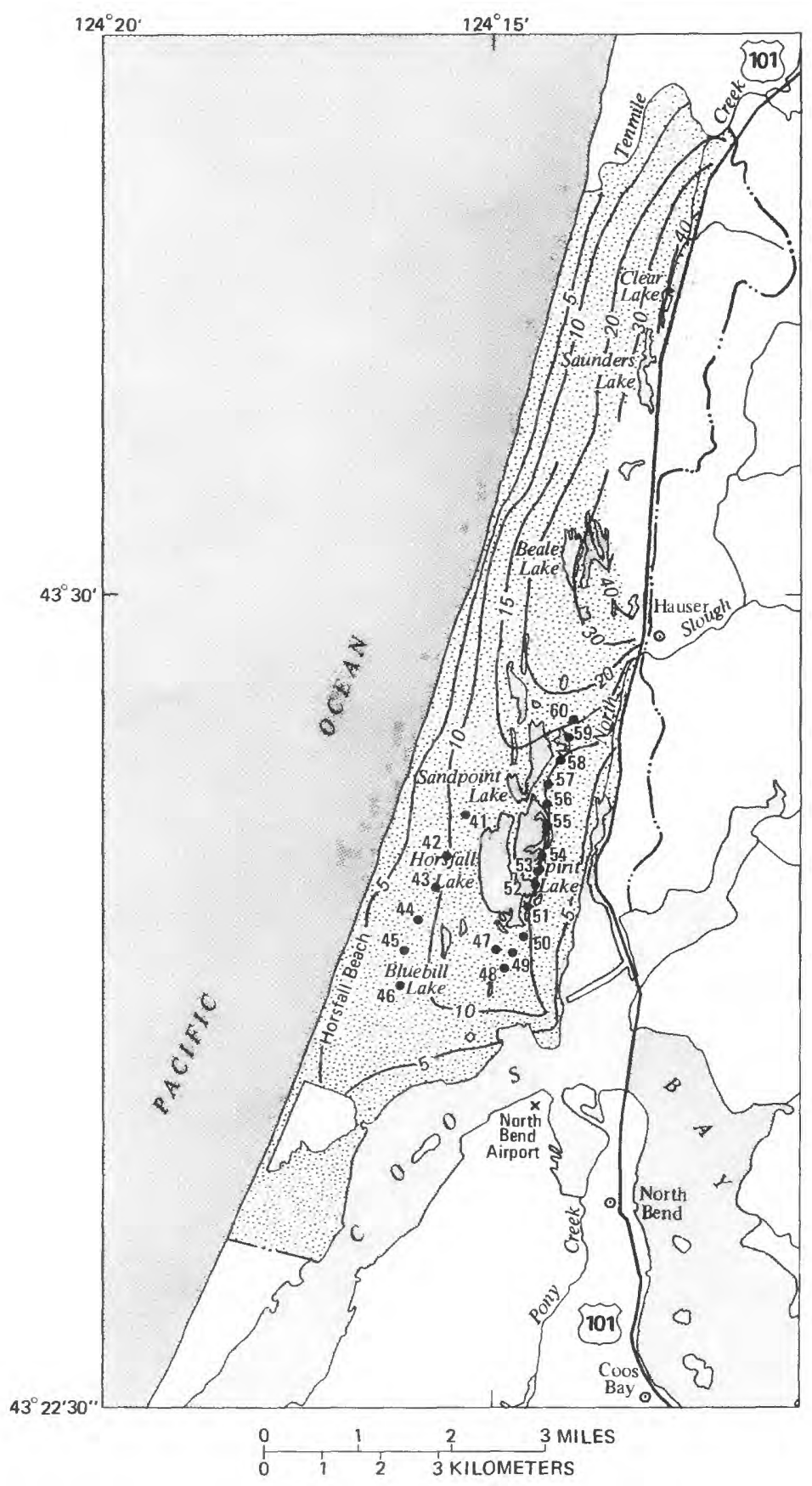

EXPLANATION

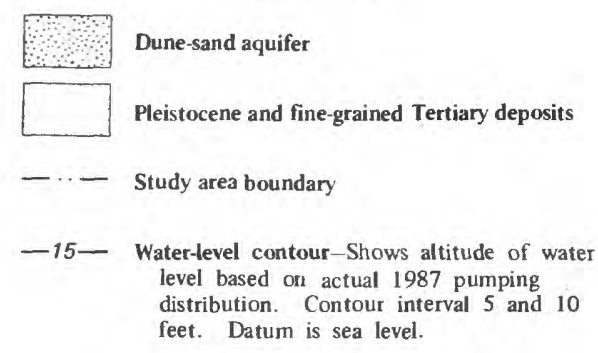

56. Production well-Number indicates Water Board's production well in 1984 (shown in table 2).

Figure 36.--Simulated water-level contours for the long-term average-annual recharge and actual 1987 pumpage. 
2. More accurate estimates of runoff and evapotranspiration to improve the confidence of captured recharge;

3. Field data on the vertical distribution within heads of underlying fine-grained deposits;

4. Hydraulic conductivities of the fine-grained deposits.

The accuracy of the model could be improved also by including in the model the pumping of ground water into lakes and the leakage from lakes to the aquifer. As pumpage increases, it would be advisable to pump from a small area at the maximum potential rate and monitor that area for water levels and chloride concentrations. These data could be used to test the reliability of the model for simulating the effects of increased pumpage and also could provide data for estimating the rate of seawater intrusion.

\section{SUMMARY AND CONCLUSIONS}

The dune aquifer presently (1987) supplies about 5 million gallons per day for industrial and municipal water use to the nearby communities of Coos Bay and North Bend. The dune aquifer is located between Coos Bay and Tenmile Creek in Coos County and is part of a discontinuous series of sand dunes extending the length of the Oregon Coast. The dune aquifer is composed of dune and marine sand of Holocene age, underlain by predominantly finer grained older Tertiary deposits.

The long-term average recharge to the dune aquifer was estimated to be 38 inches on the basis of National Weather Service data and estimates of direct runoff and evapotranspiration. Both the dune aquifer and the lakes respond quickly to the recharge from precipitation, as indicated from the seasonal water-level variations. The general direction of ground-water flow in the dune aquifer is westward to the Pacific Ocean, south and southeastward to Coos Bay and North Slough, and northward to Tenmile Creek, with ground-water gradients that range from about 10 to 50 feet per mile.

A four-layer, steady-state numerical model that simulates ground-water flow and the position of a freślwater-seawater interface was constructed for the dune area adjacent to Coos Bay and North Bend. The model was calibrated with annual-averaged data from the period October 1983 through September 1984. The root-mean-square error of the calibrated heads simulated by the model was 3.5 feet. The simulated position of the interface agreed with elevated chloride concentrations in two wells near Horsfall Beach in the southwestern part of the study area. No other data were available in the study area to verify the accuracy of the simulated interface position. The horizontal hydraulic conductivities obtained by model calibration were $0.314 \times 10^{-3}$ to $1.45 \times 10^{-3} \mathrm{ft} / \mathrm{s}$ for the dune aquifer, $0.28 \times 10^{-3} \mathrm{ft} / \mathrm{s}$ for the Pleistocene and older fine-grained Tertiary deposits exposed in the northeastern part of the study area, and $2 \times 10-6 \mathrm{ft} / \mathrm{s}$ for the fine-grained Tertiary deposits that underlie the dune aquifer. Hydraulic conductivities in the vertical direction were 0.1 the values in the horizontal direction, on the basis of simulation. The accuracy of the calibrated conductivities for the dune aquifer is considered to be higher than for the other deposits. 
The calibrated model was used to evaluate the effects of different pumpage alternatives on ground-water levels and location of the regional freshwaterseawater interface. Independent calculations were used to determine if there would be local upconing of seawater into the dune aquifer beneath each pumped well and to estimate the chloride concentration in the water pumped from each we11.

Mode1 simulations indicated that a maximum of $17 \mathrm{Mgal} / \mathrm{d}$ could be pumped from existing and proposed production wells without causing the regional interface to encroach into the dune aquifer or inducing seawater to flow into the wells. However, the risk associated with pumping this quantity over time is uncertain because of the uncertainties associated with simulated results. A pumping rate of $17 \mathrm{Mgal} / \mathrm{d}$ is equivalent to 45 percent of the average annual ground-water recharge rate of $38 \mathrm{in./yr}$ over the dune area. Simulations indicate that $10 \mathrm{Mgal} / \mathrm{d}$ could be pumped with little risk of seawater intrusion into the dune aquifer.

To minimize the probability of seawater rising into the dune aquifer in response to present (1987) pumpage, the model was used to test the redistribution of pumpage for the purpose of lowering the interface where its altitude was highest. On the basis of simulation, pumpage was reduced in the western well field and increased in the eastern well field.

The existing program of monitoring chloride concentrations in the dune aquifer needs to be expanded as the ground-water system is developed. If the ground-water system is developed to yield $10 \mathrm{Mgal} / \mathrm{d}$ or more, then chloride concentrations in the fine-grained deposits below pumping wells need to be monitored. This could be done through wells screened at depths of 100 and 200 feet below the bottom of the dune aquifer. These wells would provide warning of the upward movement of seawater toward the wells and could provide information on the rate of movement of seawater.

The reliability of the numerical model could be improved most if data on the freshwater-seawater interface in the vicinity of the pumping wells were obtained. 


\section{REFERENCES CITED}

Allen, J. E., and Baldwin, E. M., 1944, Geology and coal resources of the Coos Bay quadrangle: Oregon Department of Geology and Mineral Industries Bulletin 27, $167 \mathrm{p}$.

Baldwin, E. M., 1964, Geology of Oregon: Ann Arbor, Michigan, Edward Brothers, Inc., 165 p.

Bennett, G. D., Mundorff, M. J., and Hissain, S. A., 1968, Electric-analog studies of brine coning beneath fresh-water wells in the Punjab Region, West Pakistan: U.S. Geological Survey Water-Supply Paper 1608-J, 31 p.

Brown, R. H., 1963, Estimating the transmissibility of an artesian aquifer from the specific capacity of a well, in Bentall, Ray, Methods of determining permeability, transmissibility, and drawdown: U.S. Geological Survey Water-Supply Paper 1536-I, p. 336-338.

Dobberpuhl, R. A., Luzier, J. E., and Collins, C. A., 1985, Selected waterquality data for a coastal dunes aquifer near Coos Bay, Oregon, 1971 to 1983: U.S. Geological Survey Open-File Report 84-858, 192 p.

Freeze, R. A., and Cherry, J. A., 1979, Groundwater: New Jersey, PrenticeHall, Inc., $604 \mathrm{p}$.

Hubbert, M. K., 1940, The theory of ground-water motion: Journal of Geology, v. 48, no. 8, part 1, p. 785-944.

Prych, E. A., 1983, Numerical simulation of ground-water flow in lower Satus Creek basin, Yakima Indian Reservation, Washington: U.S. Geological Survey Water-Resources Investigation Report 82-4065, 77 p.

Reilly, T. E., Frimpter, N. H., LeBlanc, D. R., and Goodman, A. S., 1987, Analysis of steady-state saltwater upconing with application at Truro Well Field, Cape Cod, Massachusetts: Ground Water, March-April 1987, p. 194-206.

Robison, J. H., 1973, Hydrology of the dunes area north of Coos Bay, Oregon: U.S. Geological Survey Open-File Report, 62 p.

Sapik, D. B., 1988, Documentation of a steady-state saltwater intrusion model for three-dimensional ground-water flow, and user's guide: U.S. Geological Survey Open-File Report 87-526, 174 p.

U.S. Department of Agriculture, 1970, Technical release no. 21 (Rev. 2): Soil Conservation Service Engineering Division, 87 p.

-.--In press, Soil map of Coos County, Oregon: Soil Conservation Service.

U.S. Environmental Protection Agency, 1977, National secondary drinkingwater regulations: Federal Register, v. 42, no. 62, Thursday, March 31, 1977, part 1, p. 17143-17147.

Wiedemann, A. M., 1984, The ecology of Pacific Northwest coastal sand dunes: a community profile: Fish and Wildlife Service/OBS-8404, 130 p. 
APPENDIX A 
888888888888888888888888888888888888

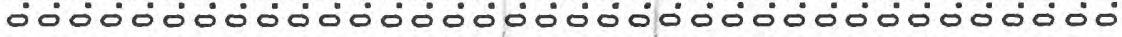

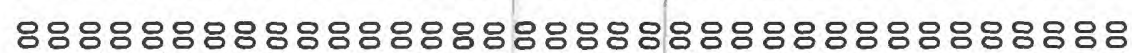

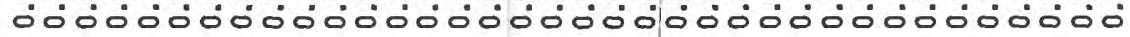

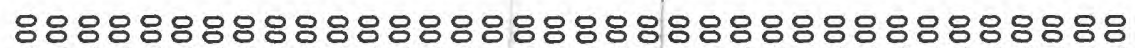

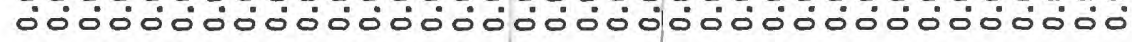

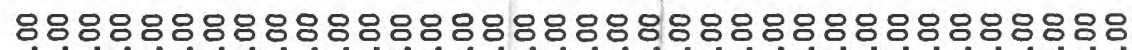

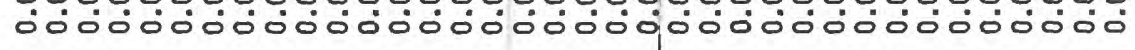
888888888888888888888888888888888888

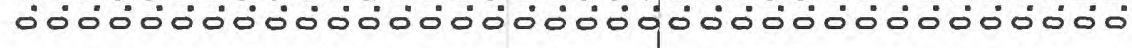
888888888888888888888888888888888888

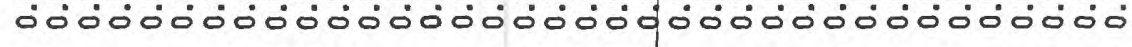
888888888888888888888888888888888888

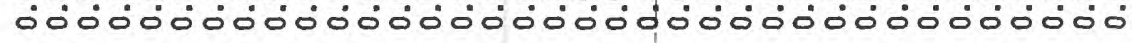

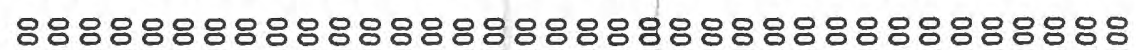

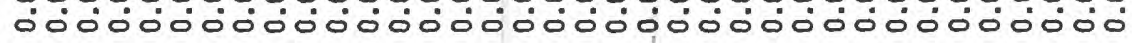

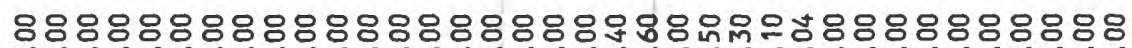

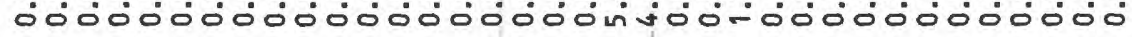

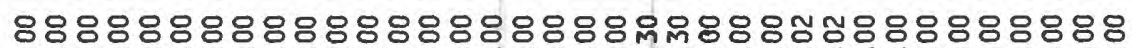

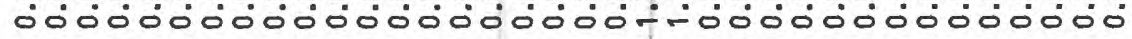
888888888888888888888888885888888888

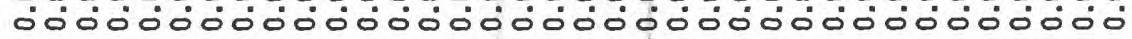

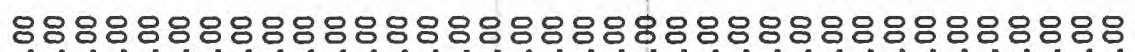

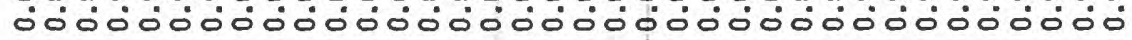
888888888888888888888888880888888880

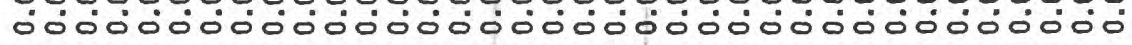

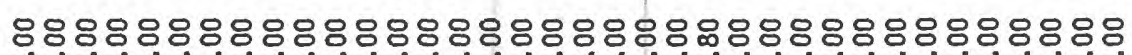

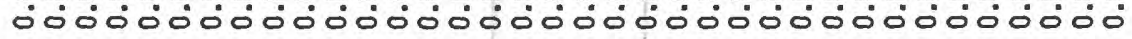

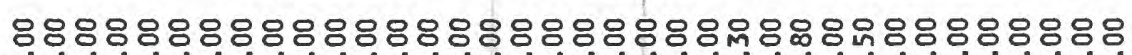

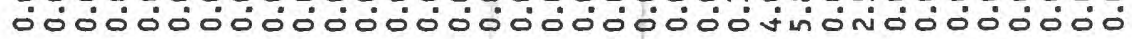

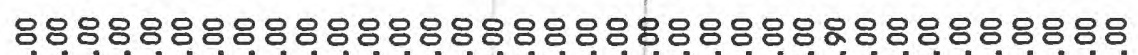
00000000000000000000000000000 888888888888888888888888888888888888

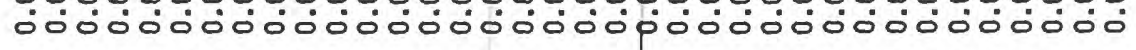
888888888888888888888888888880880880

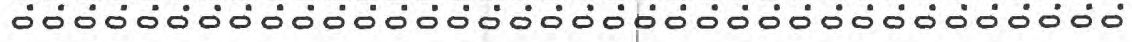

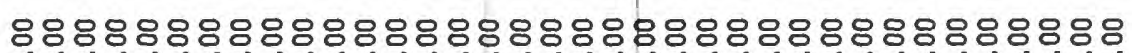

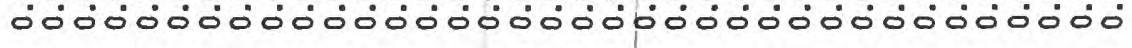

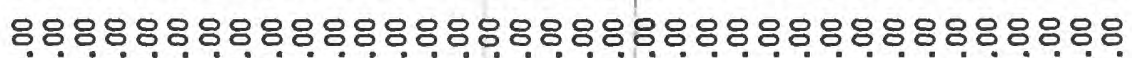

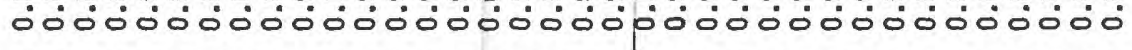

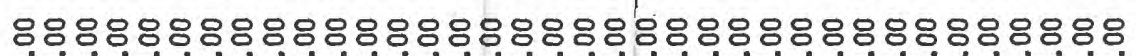

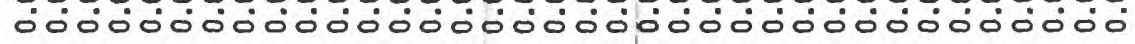

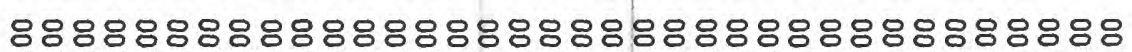

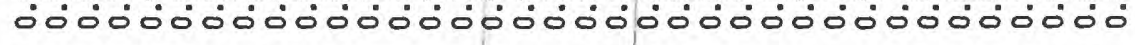

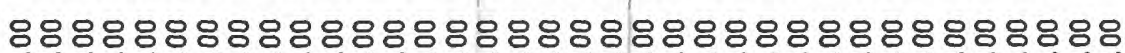

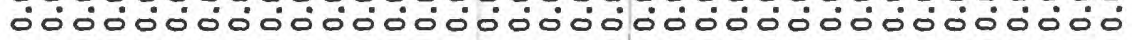
888888888888888888088888888888808888

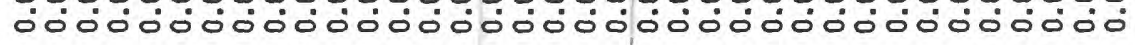

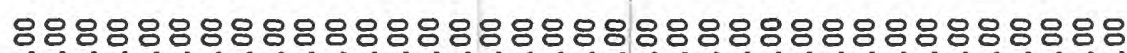

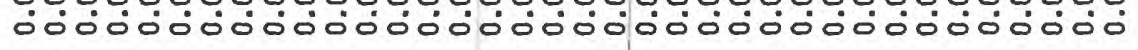

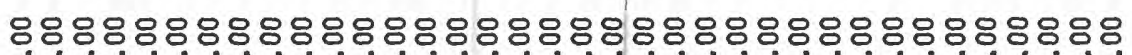
¿00000000000000000000000000000 


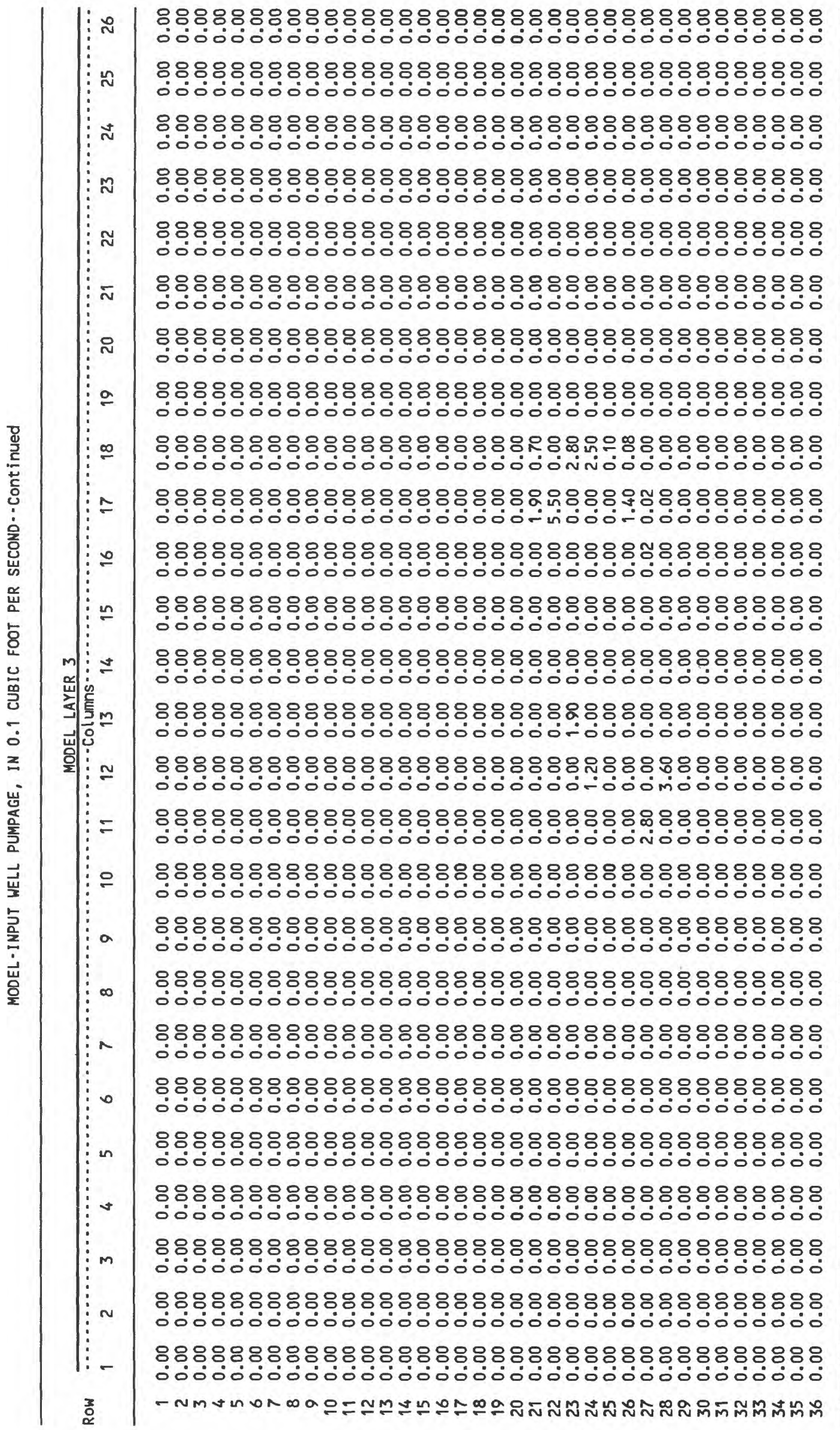




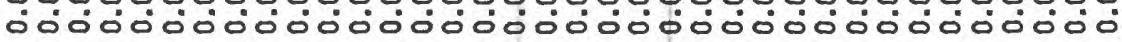

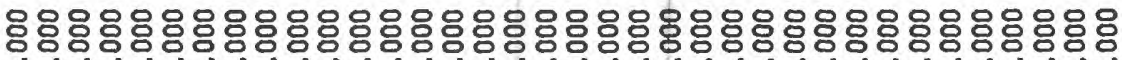

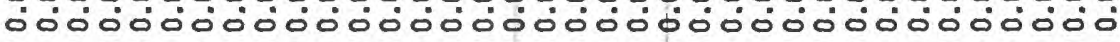

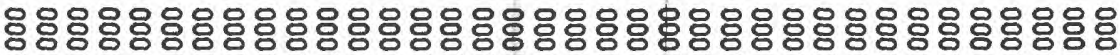

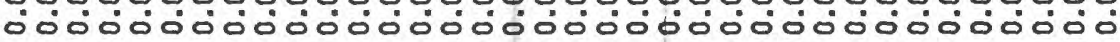

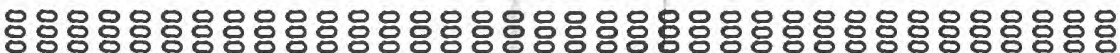

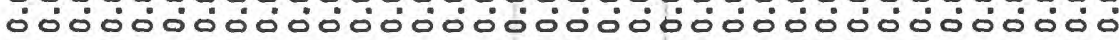

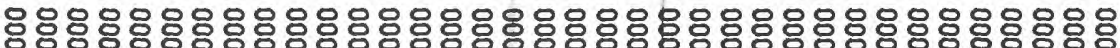

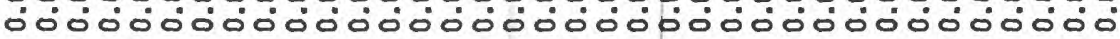

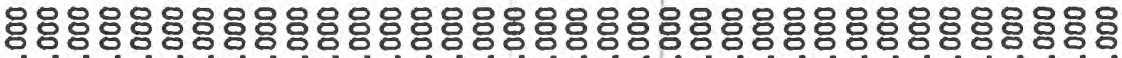

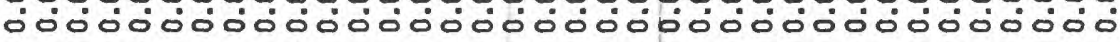

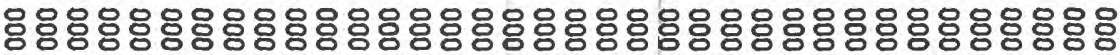

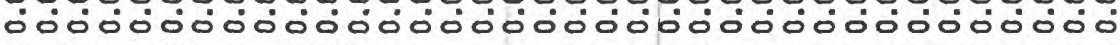

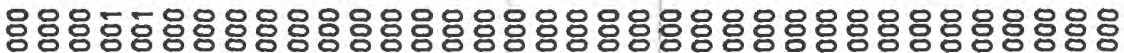

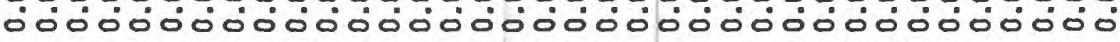

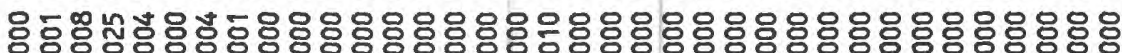

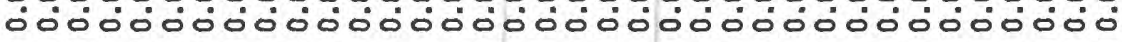

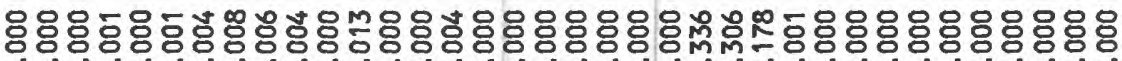

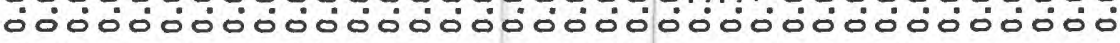

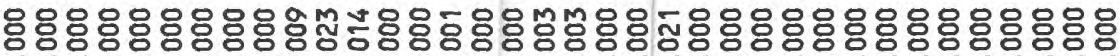

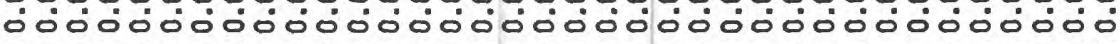

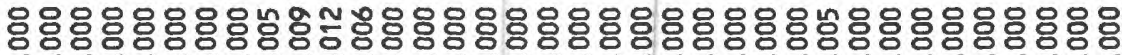

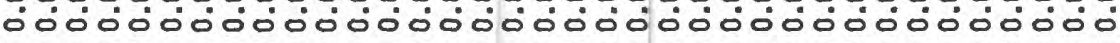

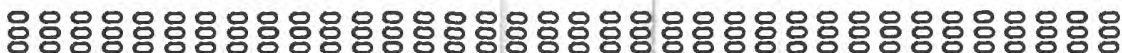

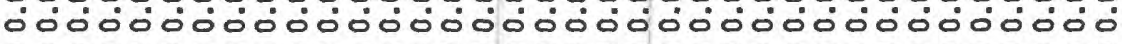

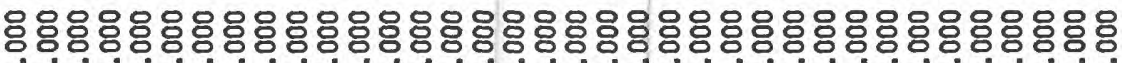

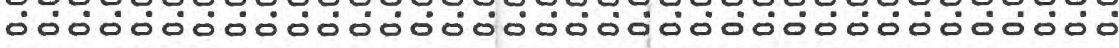

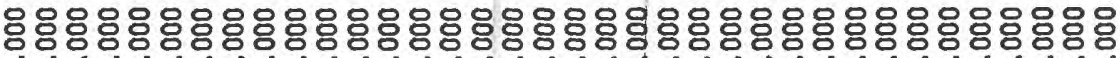

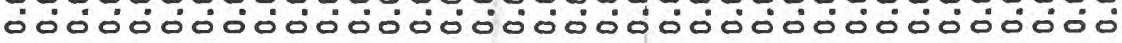

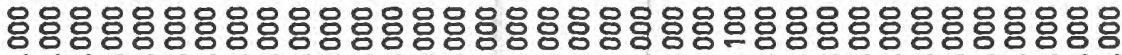

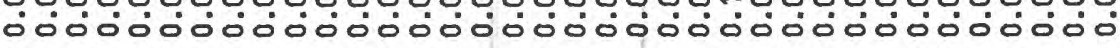

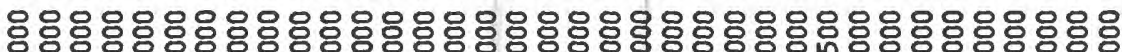

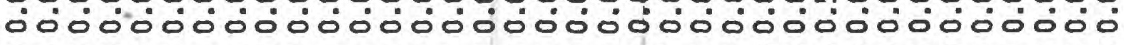

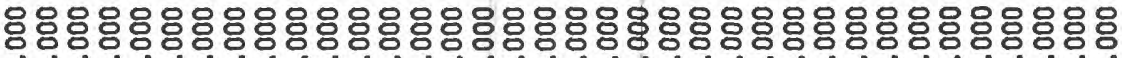

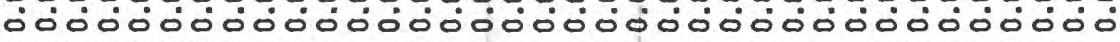

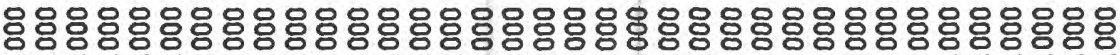

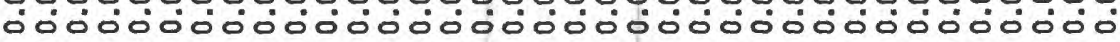

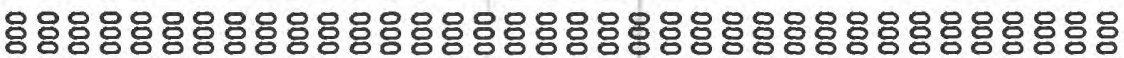

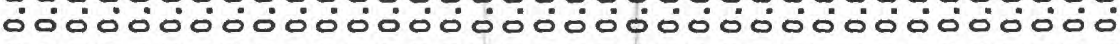

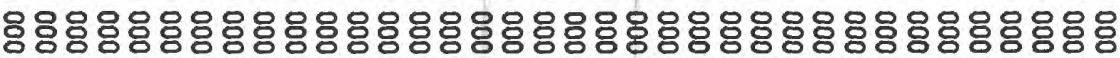

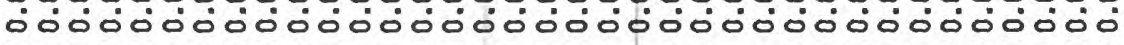

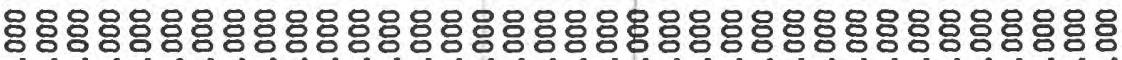

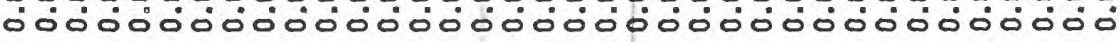

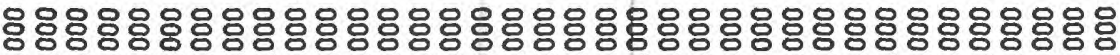

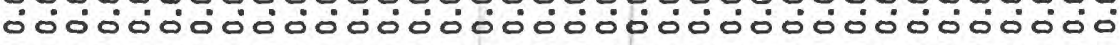

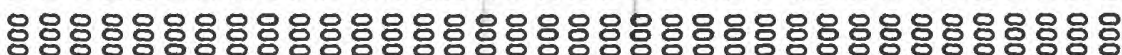

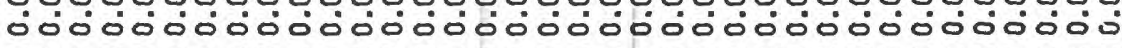

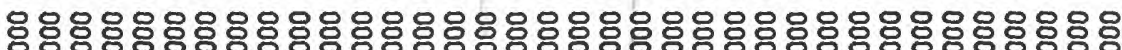

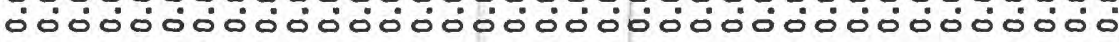

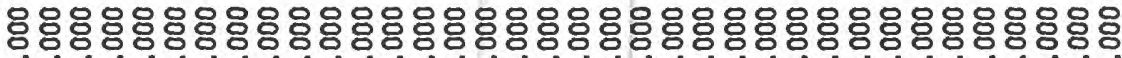

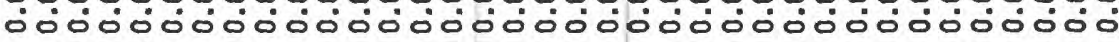
ー NMงแー 


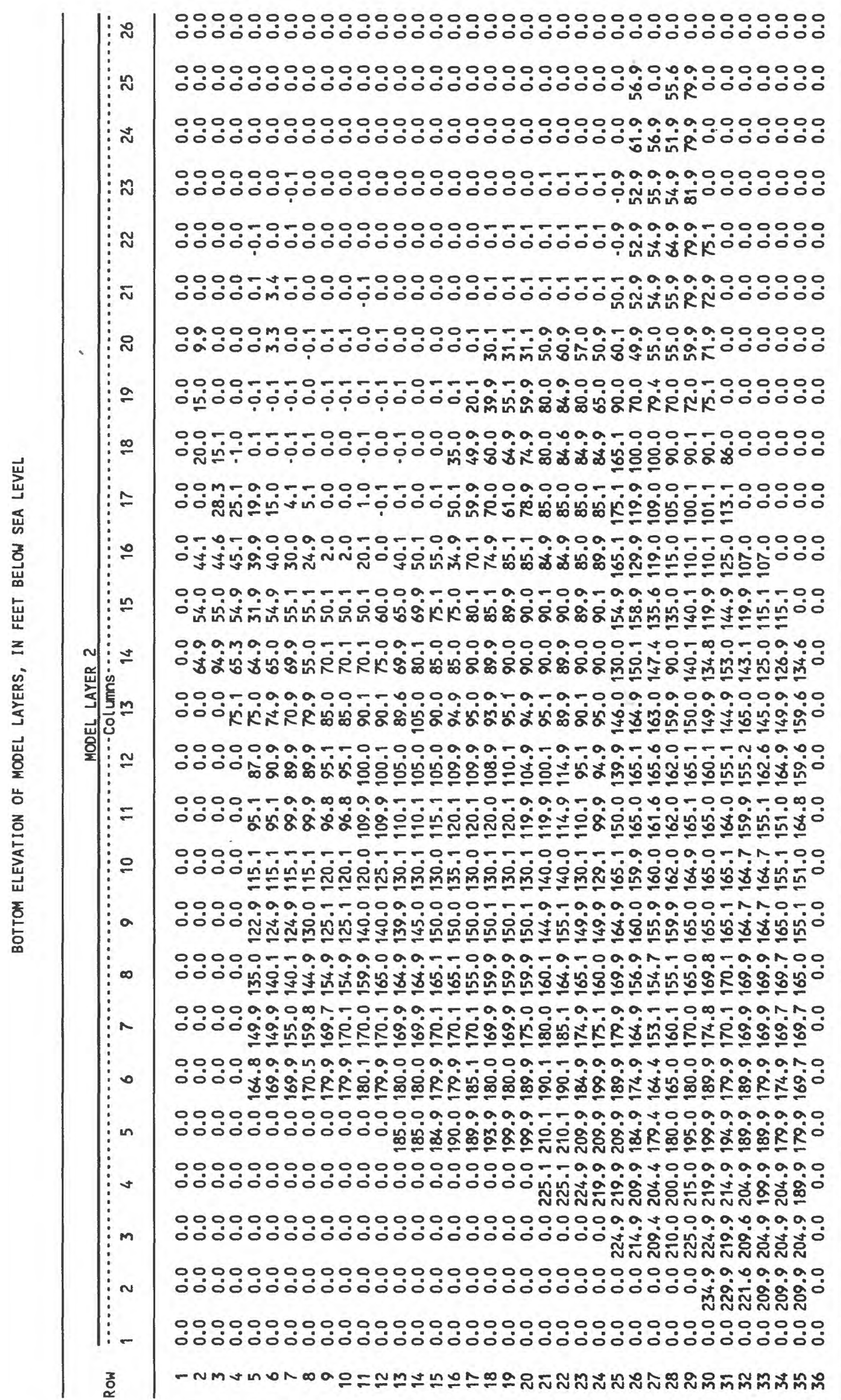


000000000000000000000000000000000000

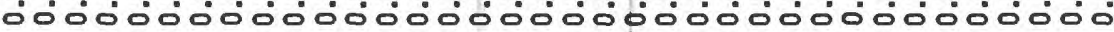

$000000000000000000000000000 \mathrm{~m} 00000000$

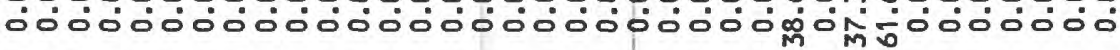
000000000000000000000000000000000000

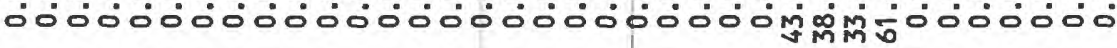
$000000+00000000000000000000000000000$

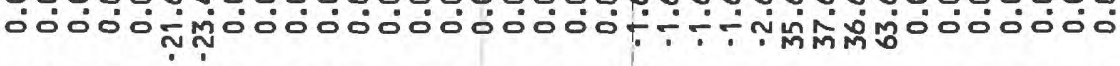
000040000000000000000000000004000000

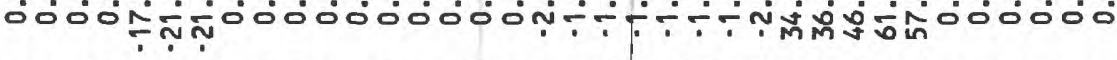

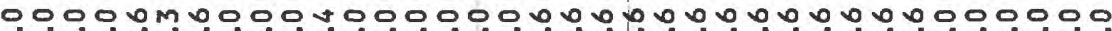
ठ0ல்

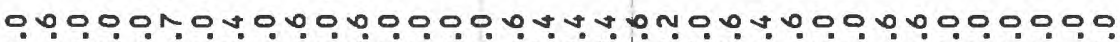

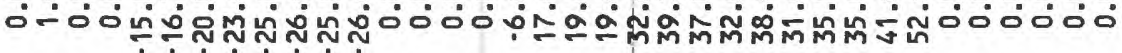

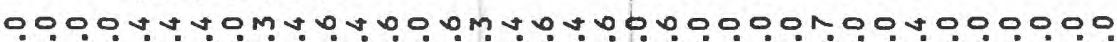

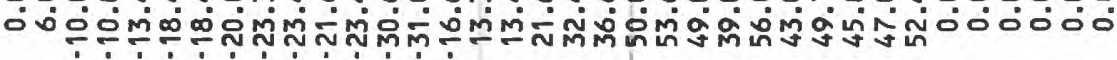
004400700040000000000000700040000000 $0004000 \% 4000000 \% 00700004400014.00000$

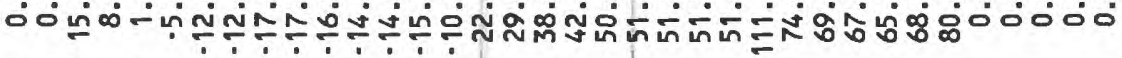
o.m.

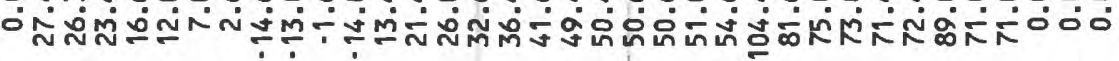

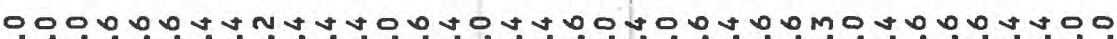

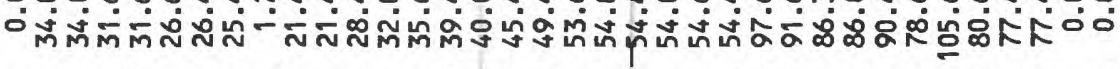
$0000000004.00400000000000400400400 m 0$

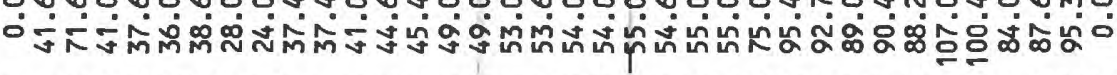

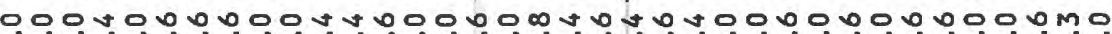

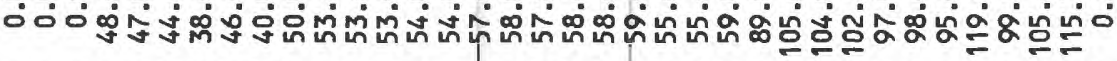

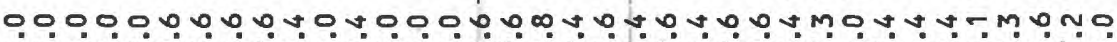
00

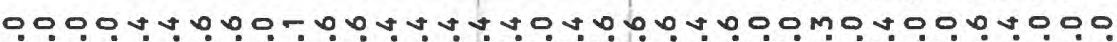

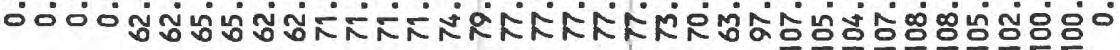

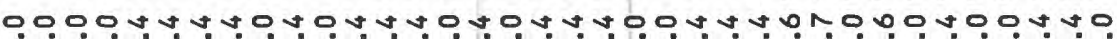

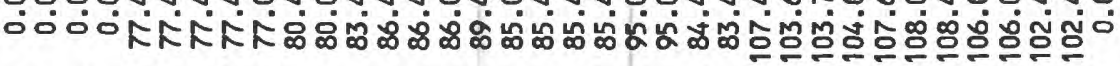
000000000400000004400400000000400000

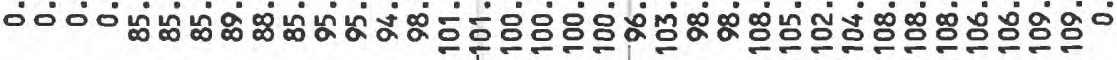

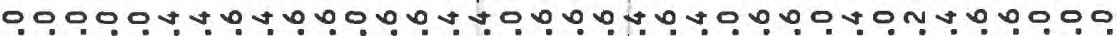

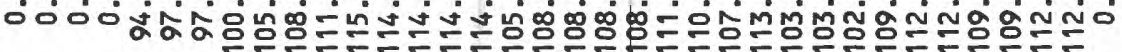

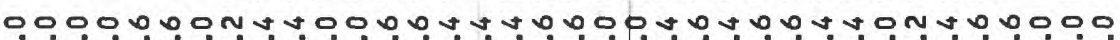
○。் 0000 N000004000000007v00001000000000

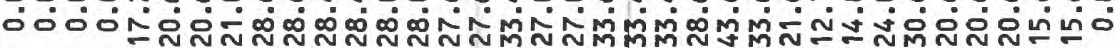

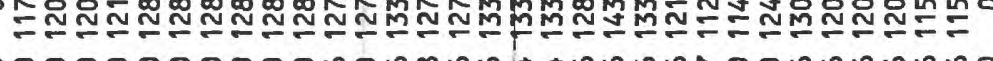
000000000000000000004000001000000000 ธ00000000000 00000000000000000000400001000000000

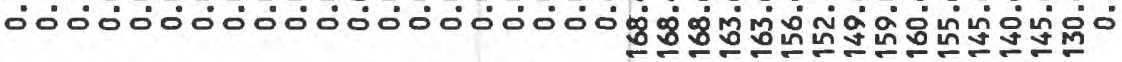
$0000000000000000000000000070000 m 0000$

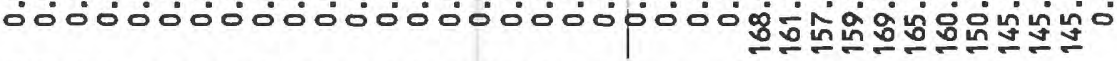
$0000000000000000000000000000000 m 0000$

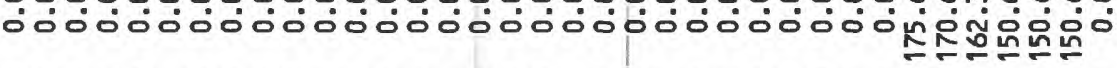
000000000000000000000000000000000000

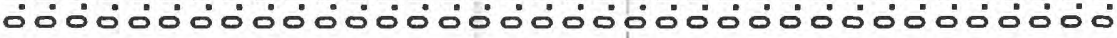

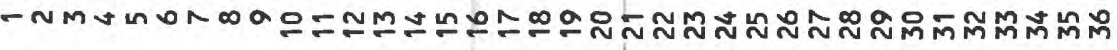




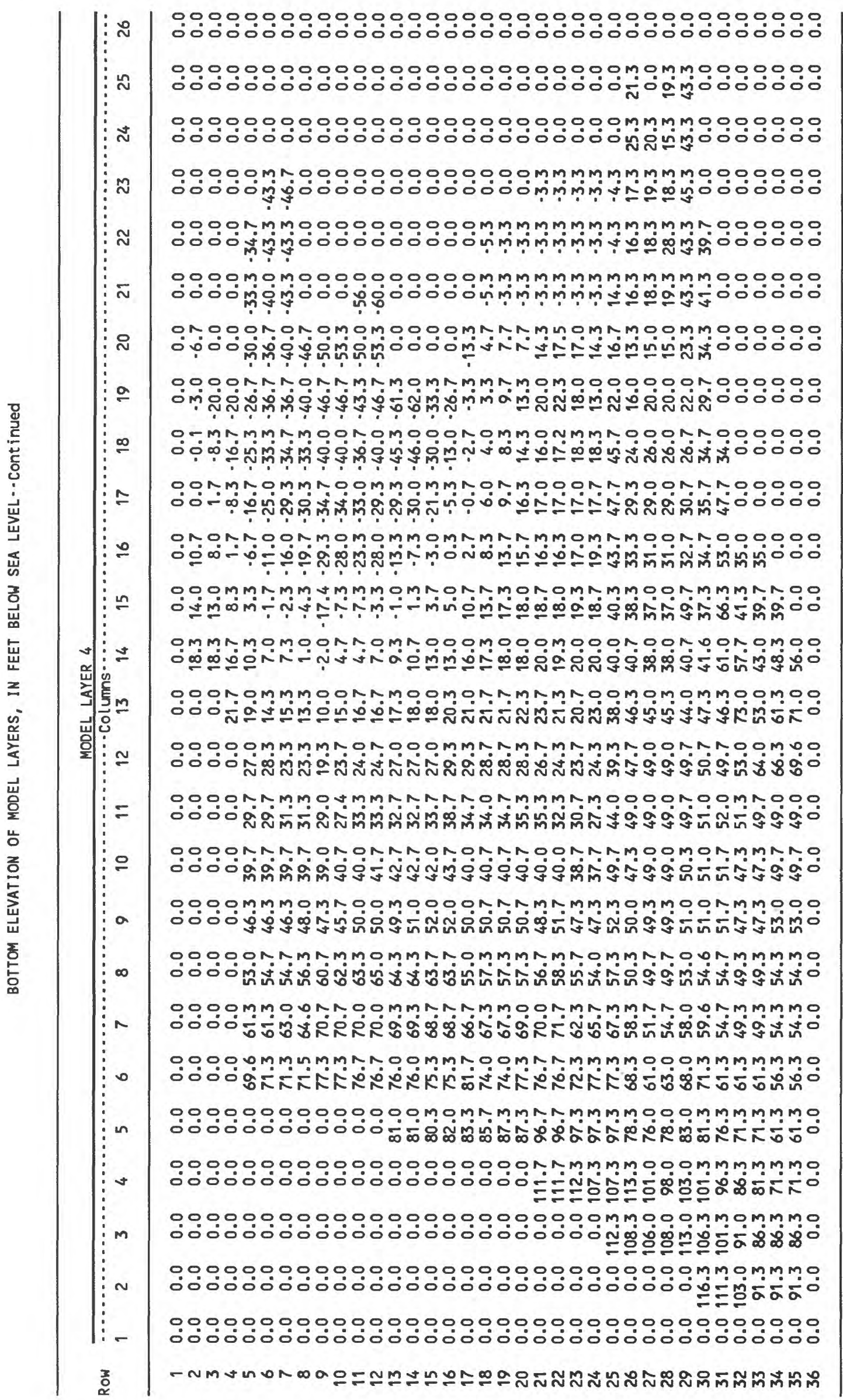




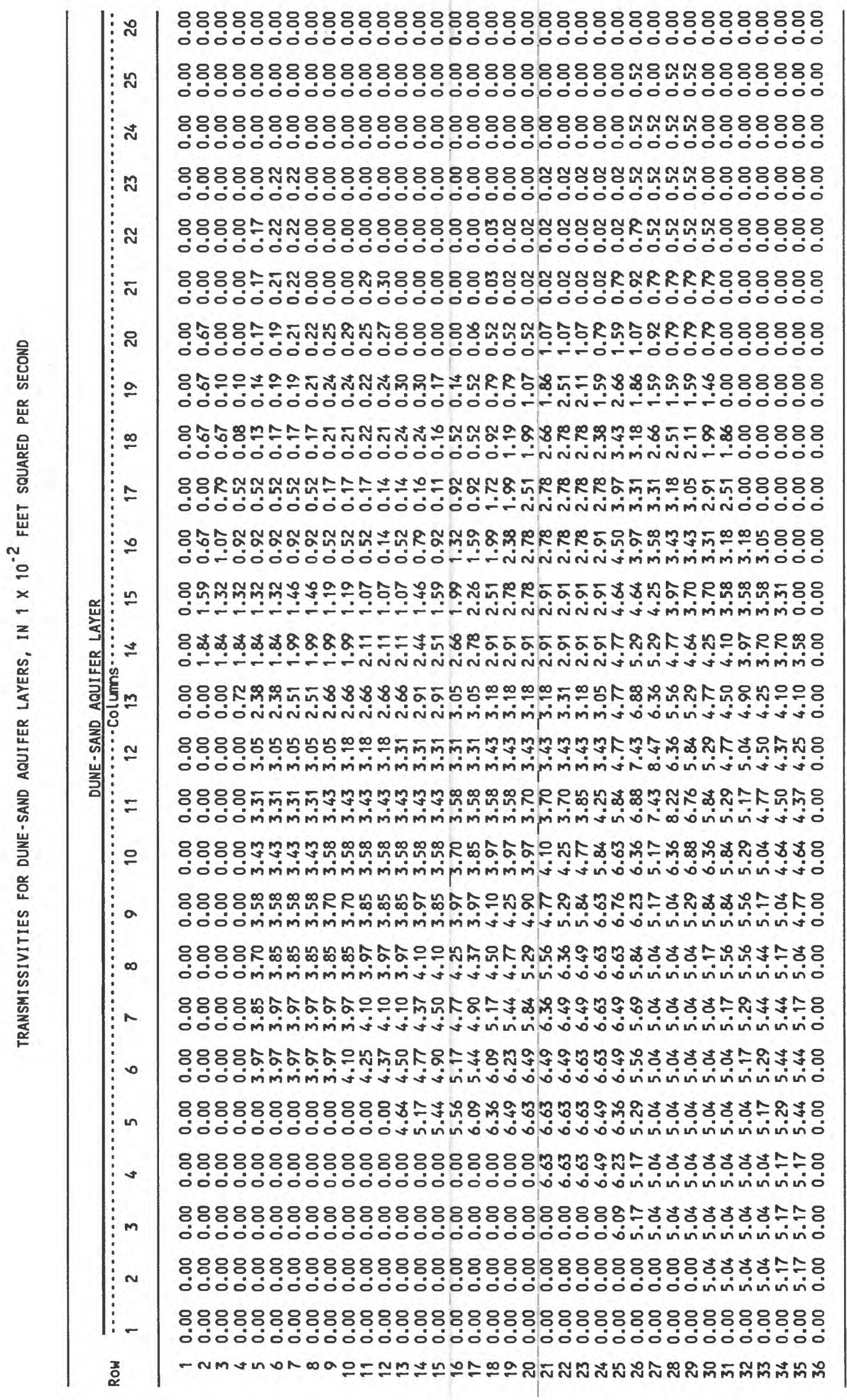




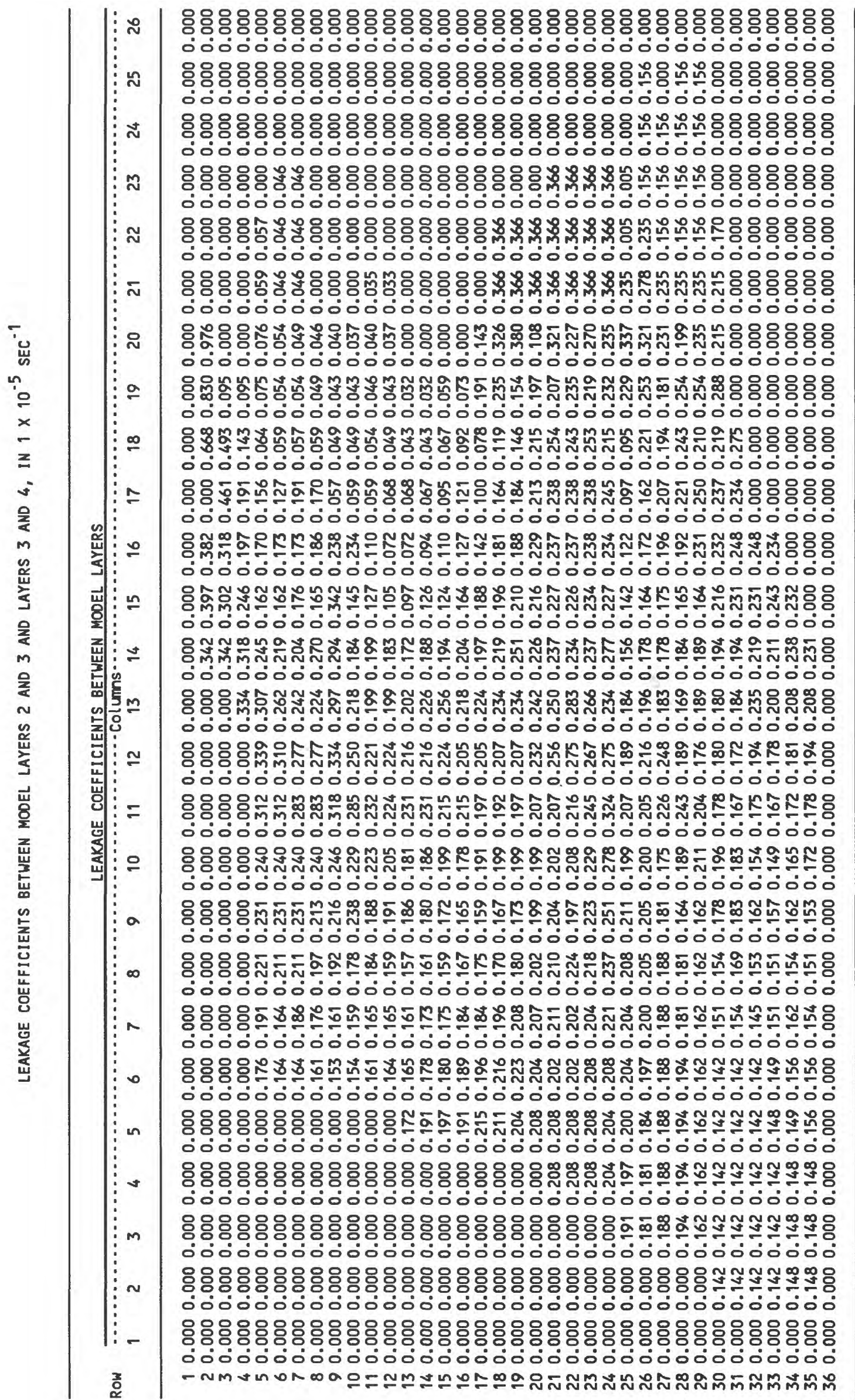




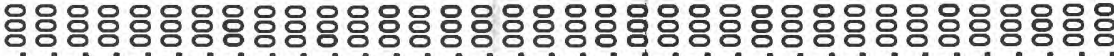

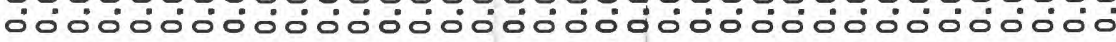

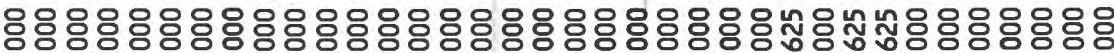

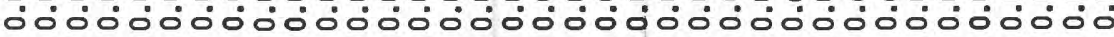

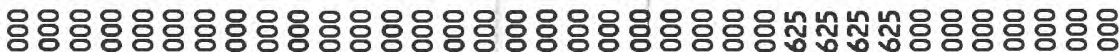

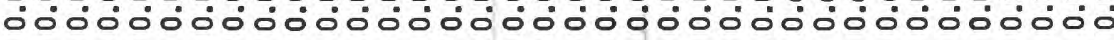

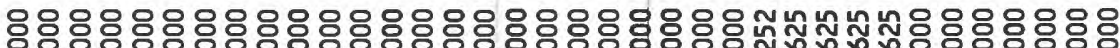

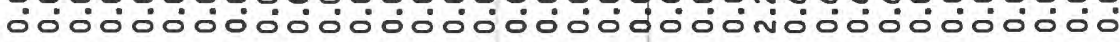

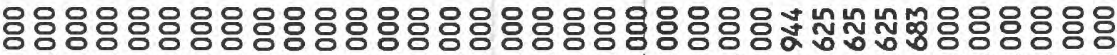

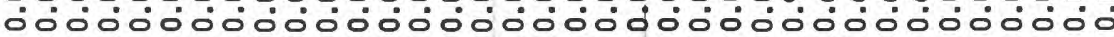

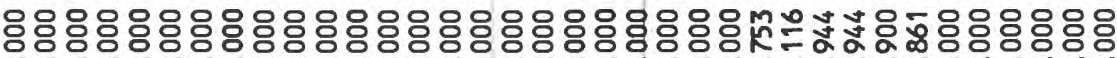

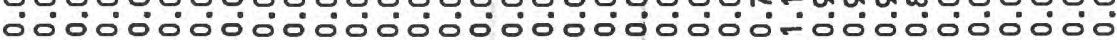

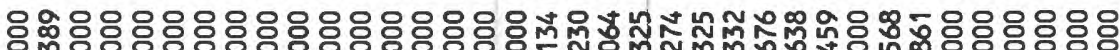

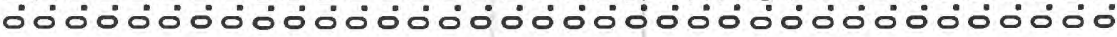

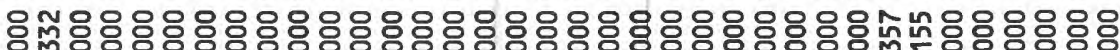

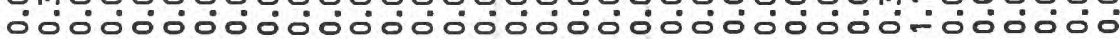

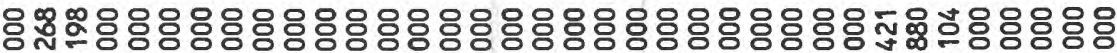

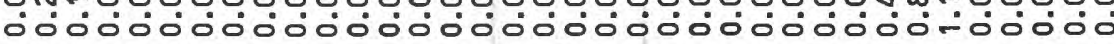

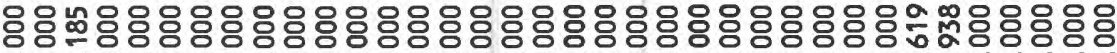

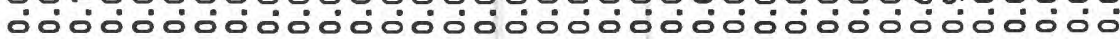

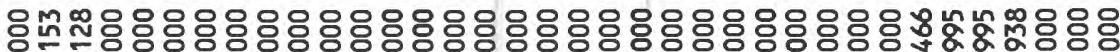

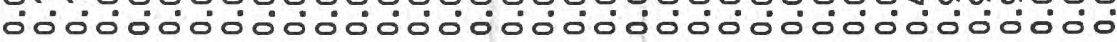

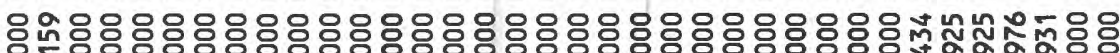

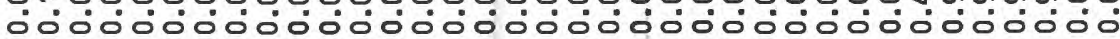

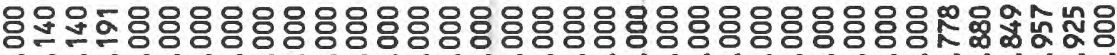

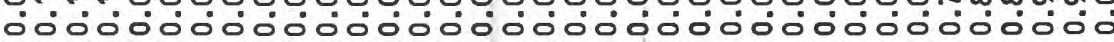

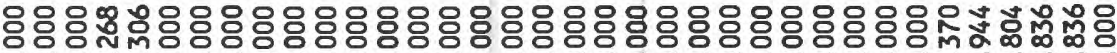

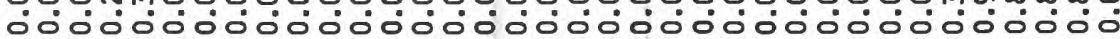

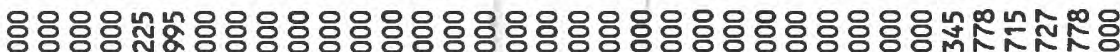

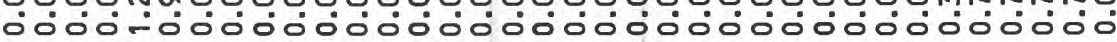

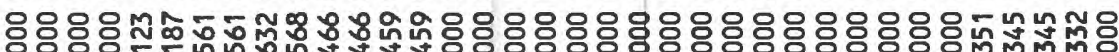

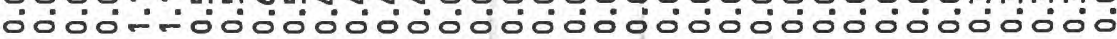

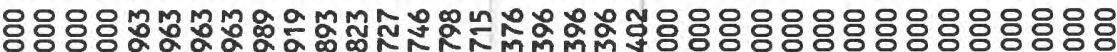

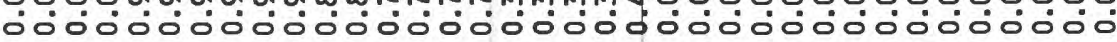

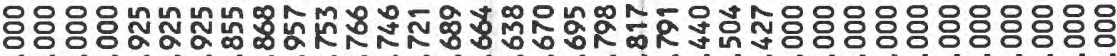

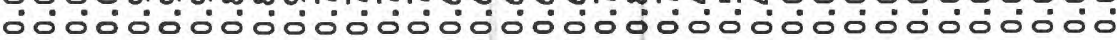

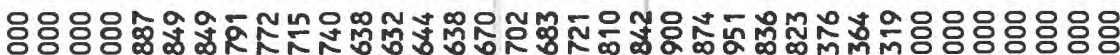

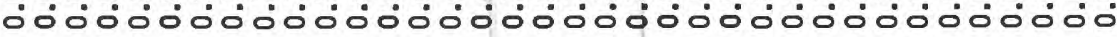

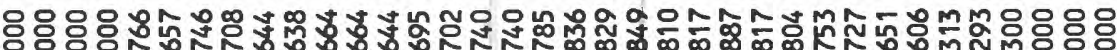

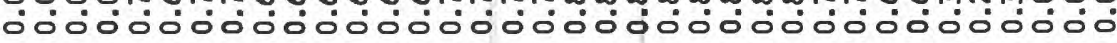

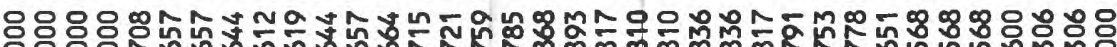

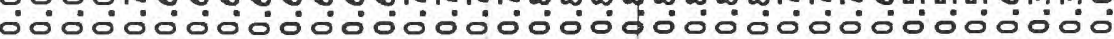

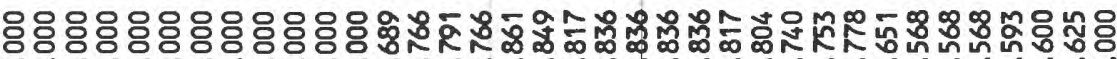

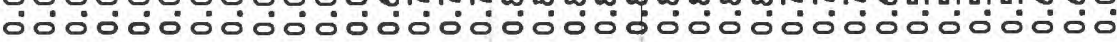

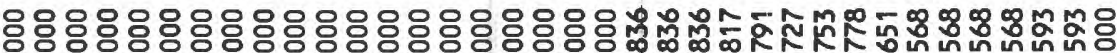

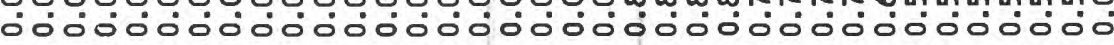
응ㅇㅇㅇㅇㅇㅇㅇㅇㅇㅇㅇㅇㅇㅇㅇㅇㅇㅇㅇㅇㅇㅇㅇㅇㅇㅇㅛ

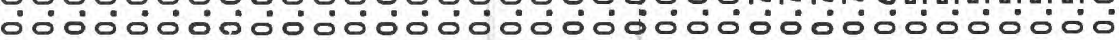

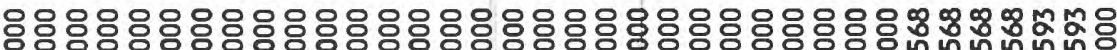

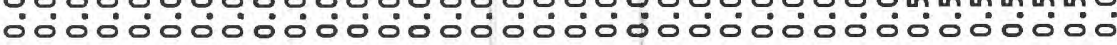
양ㅇㅇㅇㅇㅇㅇㅇㅇㅇㅇㅇㅇㅇㅇㅇㅇㅇㅇㅇㅇㅇㅇㅇㅇㅇㅇㅇㅇㅇㅇㅇㅇㅇㅇㅇㅇㅇㅇㅇㅇㅇㅇㅇㅇㅇㅇㅇㅇ

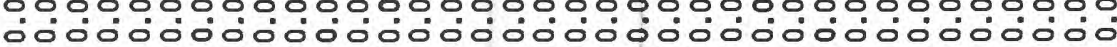

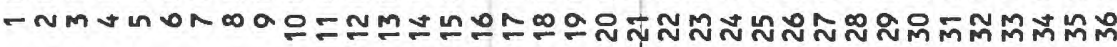

